\title{
Geochemical Variability of Soils and Biogeochemical Variability of Plants in the Piceance Basin, Colorado
}

U.S. GEOLOGICAL SURVEY PROFESSIONAL PAPER 1134-E

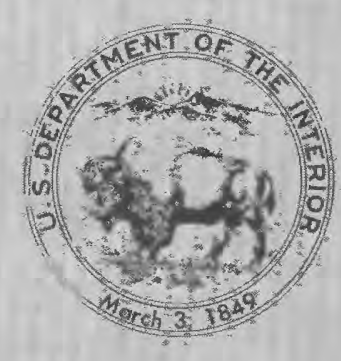




\section{Geochemical Variability of Soils and Biogeochemical Variability of Plants in the Piceance Basin, Colorado}

By M. L. TUTTLE, R. C. SEVERSON, W. E. DEAN, and R. W. KLUSMAN

GEOCHEMICAL SURVEY OF THE WESTERN ENERGY REGIONS

U.S. GEOLOGICAL SURVEY PROFESSIONAL PAPER $1134-\mathrm{E}$

A study providing background information for total and extractable element compositions of soils, mineralogy of soils, and element compositions of plants from native and altered sites in areas likely to be affected by oil-shale development

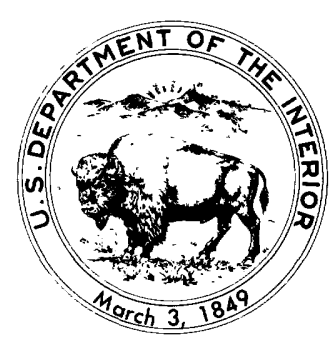


DEPARTMENT OF THE INTERIOR

DONALD PAUL HODEL, Secretary

\author{
U.S. GEOLOGICAL SURVEY
}

Dallas L. Peck, Director

\title{
Library of Congress Cataloging in Publication Data
}

Geochemical variability of soils and biogeochemical variability of plants in the Piceance Basin, Colorado.

(Geochemical survey of the western energy regions)

(Geological Survey professional paper ; 1134-E)

Bibliography: p.

Supt. of Docs. no.: I 19.16:1134-E

1. Soils-Colorado-Piceance Creek Watershed-Composition. 2. Botany-Colorado-Piceance Creek Watershed. 3. Soil chemistry-Colorado-Piceance Creek Watershed. 4. Plants-Composition. 5. Geochemistry-Colorado-Piceance Creek Watershed. 6. Biogeochemistry-Colorado-Piceance Creek Watershed. 7. Plant-soil relationships-Colorado-Piceance Creek Watershed. 8. Oil-shale industry-Environmental aspects-Colorado-Piceance Creek Watershed. 9. Piceance Creek Watershed (Colo.). I. Tuttle, M. L. II. Series. III. Series: Geological Survey professional paper ; 1134-E. 


\section{CONTENTS}

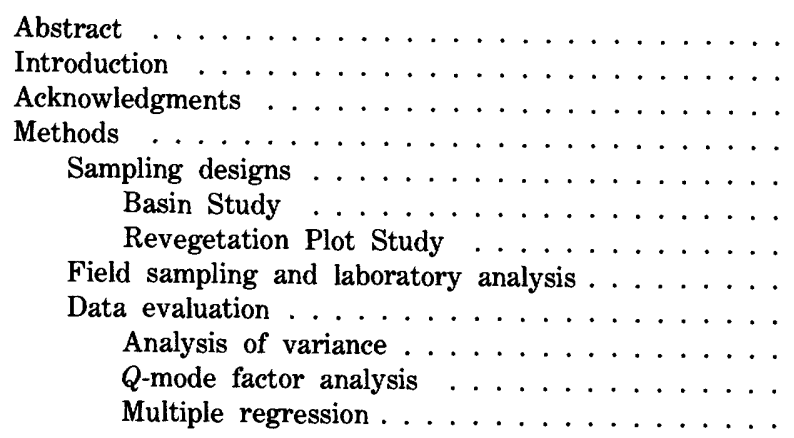

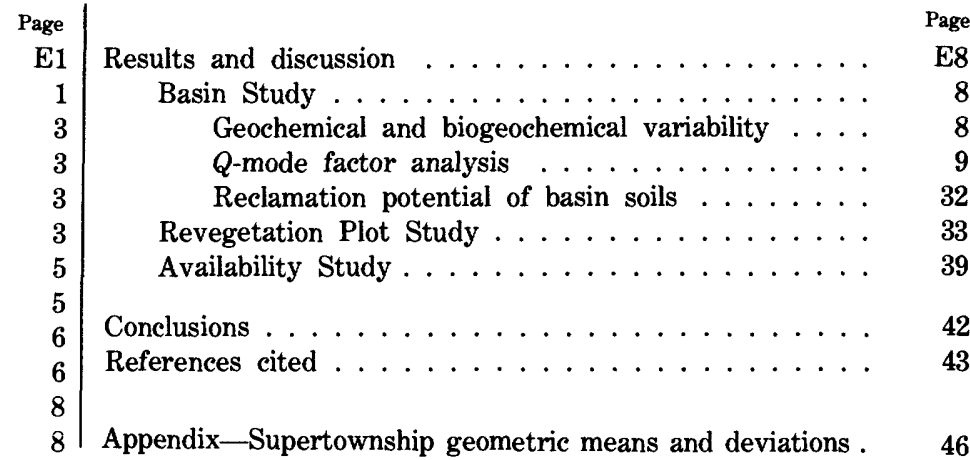

\section{ILLUSTRATIONS}

Figure 1. Map showing location of Piceance basin and areas underlain by Green River oil shale ............. E2

2. Geologic map of Piceance basin showing supertownships and sample site locations . . . . . . . . . . . . 4

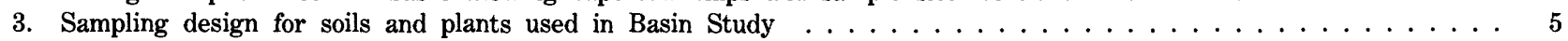

4. Sampling design for soils and plants used in Revegetation Plot Study . . . . . . . . . . . . . . . .

5. Geochemical maps for soil and biogeochemical maps for plant properties that have a variance mean ratio of 1.00 or greater . 17

6. Maps showing distribution of $Q$-mode factor loadings for soil samples . . . . . . . . . . . . . . . . 29

7. Histograms showing relation between soil properties and topsoil depth in revegetation lysimeters . . . . . . . . 38

8. Histograms showing relation between western wheatgrass properties and topsoil depth in revegetation lysimeters . 39

\section{TABLES}

1. Methods of analysis of geochemical properties of soils and biogeochemical properties of plants . . . . . . . . E6

2. Two-theta position of X-ray diffraction peaks measured to determine relative abundances of minerals in soils . . . . 7

3. Summary statistics for geochemical properties of Piceance basin soils and biogeochemical properties of Piceance basin

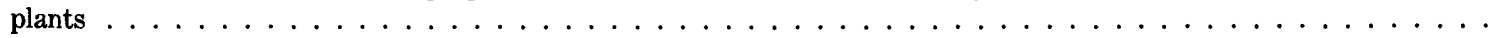

4. Total logarithmic variance and variance components for geochemical properties in Piceance basin soils and biogeochemical properties of Piceance basin plants . . . . . . . . . . . . . . . . . . .

5. Calculated parameters used in estimating stability of maps based on mean amounts of geochemical and biogeochemical properties of Piceance basin soils and plants . . . . . . . . . . . . . . . . .

6. Grouping of geochemical and biogeochemical properties based on variance mean ratios and analytical error variance of

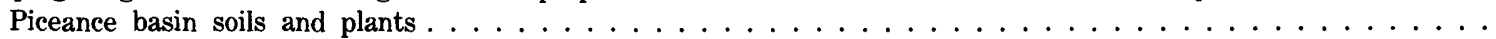

7. Compositions of $Q$-mode end-member samples and summary statistics of Piceance basin soil samples associated with each

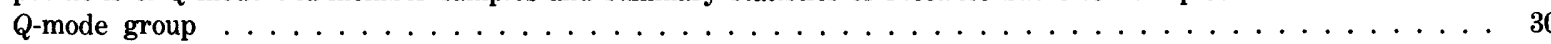

8. Summary statisties for geochemical properties of revegetation plot soil and biogeochemical properties of revegetation plot western wheatgrass $\ldots \ldots \ldots \ldots \ldots \ldots \ldots$

9. Total logarithmic variance and variance components for geochemical properties of revegetation plot soil and biogeochemical

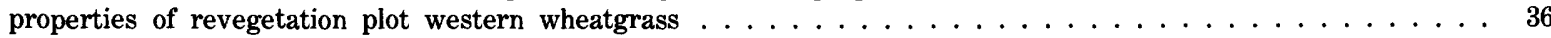

10. Comparison of mean concentrations of revegetation plot soil geochemical and western wheatgrass biogeochemical properties

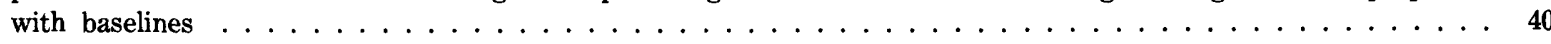

11. Relation between elemental content of Piceance basin plants and soil chemical and mineralogical properties . . . . 41

12. Regression equations showing relation between elemental content of revegetation plot western wheatgrass and soil chemical

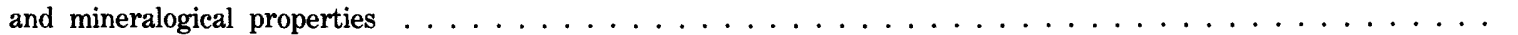





\title{
GEOCHEMICAL VARIABILITY OF SOILS AND BIOGEOGHEMICAL VARIABILITY OF PLANTS IN THE PICEANCE BASIN, COLORADO
}

\author{
By M. L. Tuttle, R. C. Severson, W. E. Dean, and R. W. Klusman ${ }^{1}$
}

\begin{abstract}
Geochemical baselines for native soils and biogeochemical baselines for plants in the Piceance basin provide data that can be used to assess geochemical and biogeochemical effects of oil-shale development, monitor changes in the geochemical and biogeochemical environment during development, and assess the degree of success of rehabilitation of native materials after development. Baseline values for 52 properties in native soils, 15 properties in big sagebrush, and 13 properties in western wheatgrass were established. Our Study revealed statistically significant regional variations of the following properties across the basin: in soils -aluminum, cobalt, copper, iron, manganese, sodium, nickel, phosphorus, lead, scandium, titanium, vanadium, zinc, organic and total carbon, $\mathrm{pH}$, clay, dolomite, sodium feldspar, and DTPA-extractable calcium, cadmium, iron, potassium, manganese, nickel, phosphorus, yttrium, and zinc; in big sagebrushbarium, calcium, copper, magnesium, molybdenum, sodium, strontium, zinc, and ash; and in western wheatgrass-boron, barium, calcium, magnesium, manganese, molybdenum, strontium, zinc, and ash. These variations show up as north-south trends across the basin, or they reflect differences in elevation, hydrology, and soil parent material. Baseline values for properties that do not have statistically significant regional variations can be represented by geometric means and deviations calculated from all values within the basin.

Chemical and mineralogical analyses of soil and chemical analyses of western wheatgrass samples from Colorado State University's experimental revegetation plot at Anvil Points provide data useful in assessing potential effects on soil and plant properties when largescale revegetation operations begin. The concentrations of certain properties are related to the presence of topsoil over spent shale in the lysimeters. In soils, calcium, fluorine, lithium, magnesium, sodium, phosphorus, strontium, carbonate and total carbon, and DTPAextractable boron, copper, iron, magnesium, and nickel have lower concentrations in topsoil than in the spent oil shale; whereas, silicon, titanium, ytterbium, clay, quartz, and DTPA-extractable potassium have greater concentrations in the topsoil than in the spent oil shale. In western wheatgrass, molybdenum has a lower concentration in grasses growing on the topsoil than in grasses on the spent oil shale; whereas, barium, calcium, manganese, strontium, zinc, and ash have greater concentrations in grasses growing on the topsoil than on the spent oil shale. When compared to baseline values, soils in the revegetation plot are significantly higher in concentrations of lead, zinc, organic and total carbon, and DTPA-extractable cadmium, iron, man-
\end{abstract}

${ }^{1} \mathrm{R}$. W. Klusman is with the Department of Chemistry and Geochemistry, Colorado School of Mines, Golden, Colorado 80401. ganese, nickel, phosphorus, and zinc. Whereas, western wheatgrass grown within the revegetation plot has concentrations which fall within the baseline values established in the regional study.

The equations used in predicting concentrations of elements in plants from native and altered sites are cumbersome because of the large number of variables required to adequately predict expected concentrations and are of limited use because many explained only a small proportion of the total variation.

\section{INTRODUCTION}

The need for reducing United States reliance on imported fuels and increasing the use of domestic energy resources has resulted in considerable research and development in alternative energy sources. To meet these energy-related needs, much work is currently being done towards finding an economically and environmentally sound way of extracting shale oil from the Green River Formation. Oil-shale deposits of the formation in Colorado, Utah, and Wyoming (fig. 1) are reported to contain the largest known oil reserve in the world (Murray and Haun, 1974).

The Piceance basin in northwestern Colorado contains an estimated 80 percent of the entire shale-oil resources of the Green River Formation-the equivalent of approximately 1,200 billion barrels of oil (Murray and Haun, 1974). Several prototype lease tracts in the basin are currently undergoing preliminary stages of commercial development. Prior to any large-scale development, it is important to provide background data which can be used to (1) assess potential geochemical and biogeochemical impact of large-scale, commercial oilshale development, (2) monitor changes in the geochemical and biogeochemical environment as a result of development, and (3) assess the potential for post-mining rehabilitation.

This report describes three studies which were conducted within the Piceance basin to provide the necessary background geochemical and biogeochemical infor- 

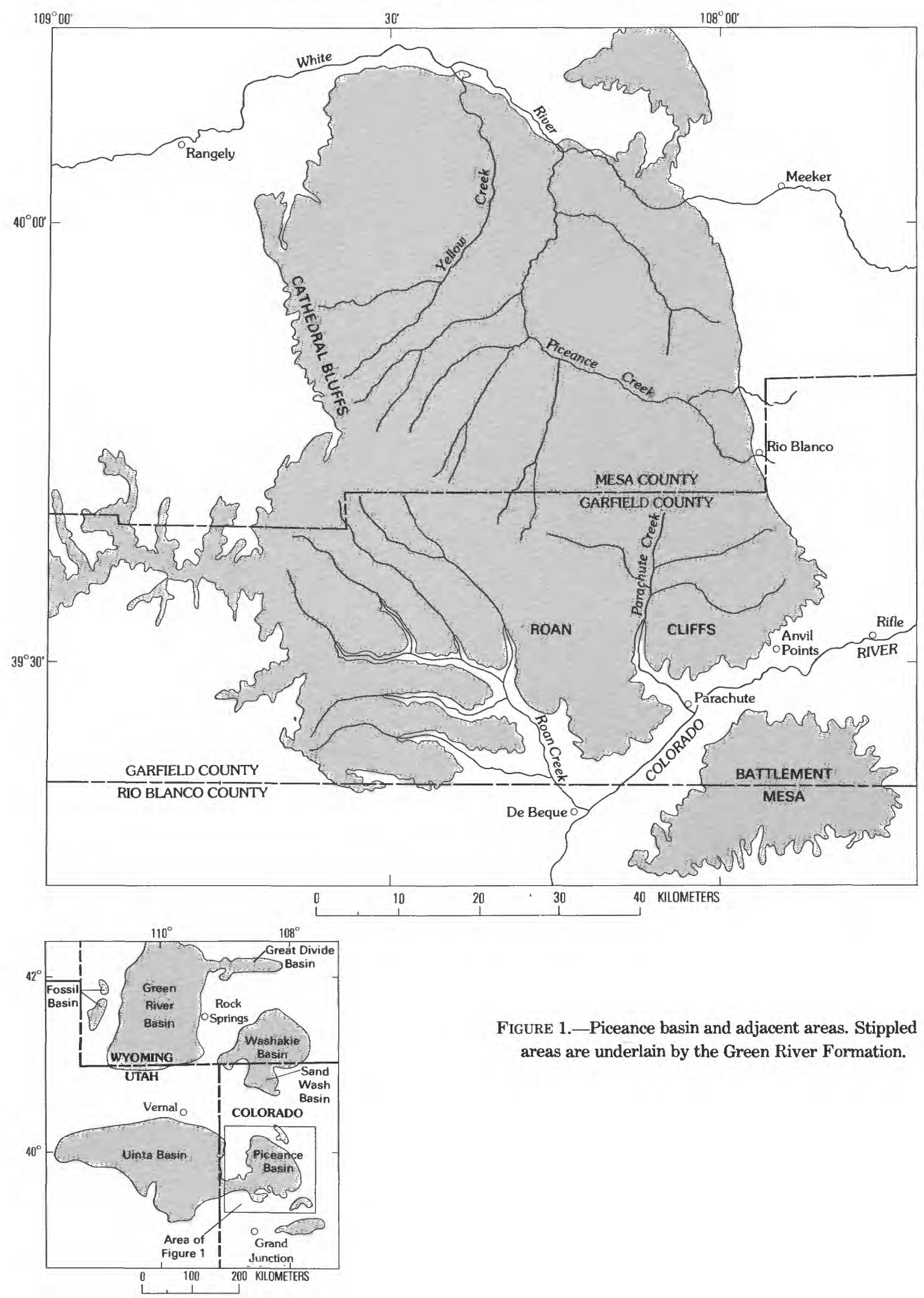

Figure 1.-Piceance basin and adjacent areas. Stippled areas are underlain by the Green River Formation. 
mation. The first study, called the Basin Study, establishes geochemical and biogeochemical baselines ${ }^{2}$ for soils and plants for the entire Piceance basin. Differences in elevation, vegetation, climate, and geology within the Piceance basin were considered as possible factors in explaining geochemical and biogeochemical differences in soils and plants from various parts of the basin.

The Piceance basin of northwestern Colorado consists of a 4500-square-kilometer plateau between the Colorado and White Rivers (fig. 1). The elevation within this plateau ranges from about 1675 meters to 2865 meters. From the rim of the Roan Cliffs west of Rifle, Colo., the land slopes gently downward to the north and is dissected by a succession of north-south trending ridges and valleys. The vegetation on the lower elevation ridges and in the valleys is predominantly sagebrush, piñon, and juniper; groves of aspen and pine grow on the tops of the higher ridges. The soils are predominantly clay loams, often with abundant lithic fragments, and little more than an $\mathrm{A}$ and $\mathrm{C}$ horizon profile development. Three formations crop out within the study area (fig. 2). The Wasatch Formation (Paleocene and lower Eocene), a fluvial deposit of claystone and shale with lenses of sandstone, is exposed around the basin edges. The Green River Formation (Eocene), a lacustrine, dolomitic, kerogen-rich marlstone, crops out in steep cliffs above the Wasatch Formation. The Uinta Formation (Eocene), a fluvial deposit of sandstone and siltstone, overlies the Green River Formation.

The second study, called the Revegetation Plot Study, examines geochemical and biogeochemical properties of topsoil and plants at Colorado State University's experimental revegetation plot at Anvil Points (Harbert and Berg, 1974). Comparison of data from this study with baselines for soils and plants from the first study aids in evaluating potential effects on soils and plants when large-scale revegetation operations begin. In addition, the effect of varying amounts of topsoil over spent shale on the uptake of elements by plants was investigated.

The third study, called the Availability Study, examines the usefulness of predicting element availability in native and altered soils by relating soil geochemical properties to plant uptake. Element availability of soils is determined in the laboratory by analyzing soil extracts. In this study, the extractant used was dieth-

\footnotetext{
${ }^{2}$ Tidball and Ebens (1976) define geochemical baselines as "the natural value of a given geochemical measurement in a given sample that one would expect in the absence of man-induced alterations."
}

ylenetriaminepentaacetic acid (DTPA) because it is Jmmonly used for estimating availability of trace metals in carbonate-rich agricultural soils (Lindsay and Norvell, 1978). It has been suggested (Severson and others, 1977) that there are multivariate relations in a native soil-plant system. Therefore, availability, measured as element concentrations in plants, was predicted using not only soil extract element concentrations, but also total soil element concentrations, soil $\mathrm{pH}$, soil organic and total carbon content, and soil mineralogy. This last study is important in determining if the availability of elements in soils can be predicted, and if so, whether a comparison of element availability can be made between altered and native environments.

\section{ACKNOWLEDGMENTS}

We wish to thank our colleagues for their assistance in the analyses of soil and plant samples. The analyses were performed in the laboratories of the U.S. Geological Survey in Denver, Colo., by James Baker, Stephen Deluca, Brook Hatfield, Johnnie Gardner-McDade, Georgia Mason, Violet Merritt, Harriet Neiman, George Riddle, Van Shaw, and James Wahlberg. We especially thank Paul Briggs, Fred Lichte, and Janet Peard for their development of analytical methods.

We express our thanks to Kathleen Kilkelly and William Berg of Colorado State University for their permission to collect soil and western wheatgrass at the Anvil Points experimental revegetation plot.

\section{METHODS SAMPLING DESIGNS BASIN STUDY}

An unbalanced, nested, analysis-of-variance sampling design was used to estimate variability for each geochemical and biogeochemical property determined in A-horizon soils, western wheatgrass (Agropyron smithii Rydb.), and big sagebrush (Artemisia tridentata Nutt.) at four distance-related increments-supertownships, townships, sections, and samples within sections (fig. 3). This design was based on one previously used by Dean, Ringrose, and Klusman (1979). Each supertownship contains four adjacent townships and is an area 19.3 kilometers (12 miles) on a side. Twelve supertownships provided adequate coverage of the study area (fig. 2). Within each supertownship, 2 of the 4 townships were randomly selected and within each township, 2 of the 36 sections were randomly selected. One of the two selected sections was randomly 


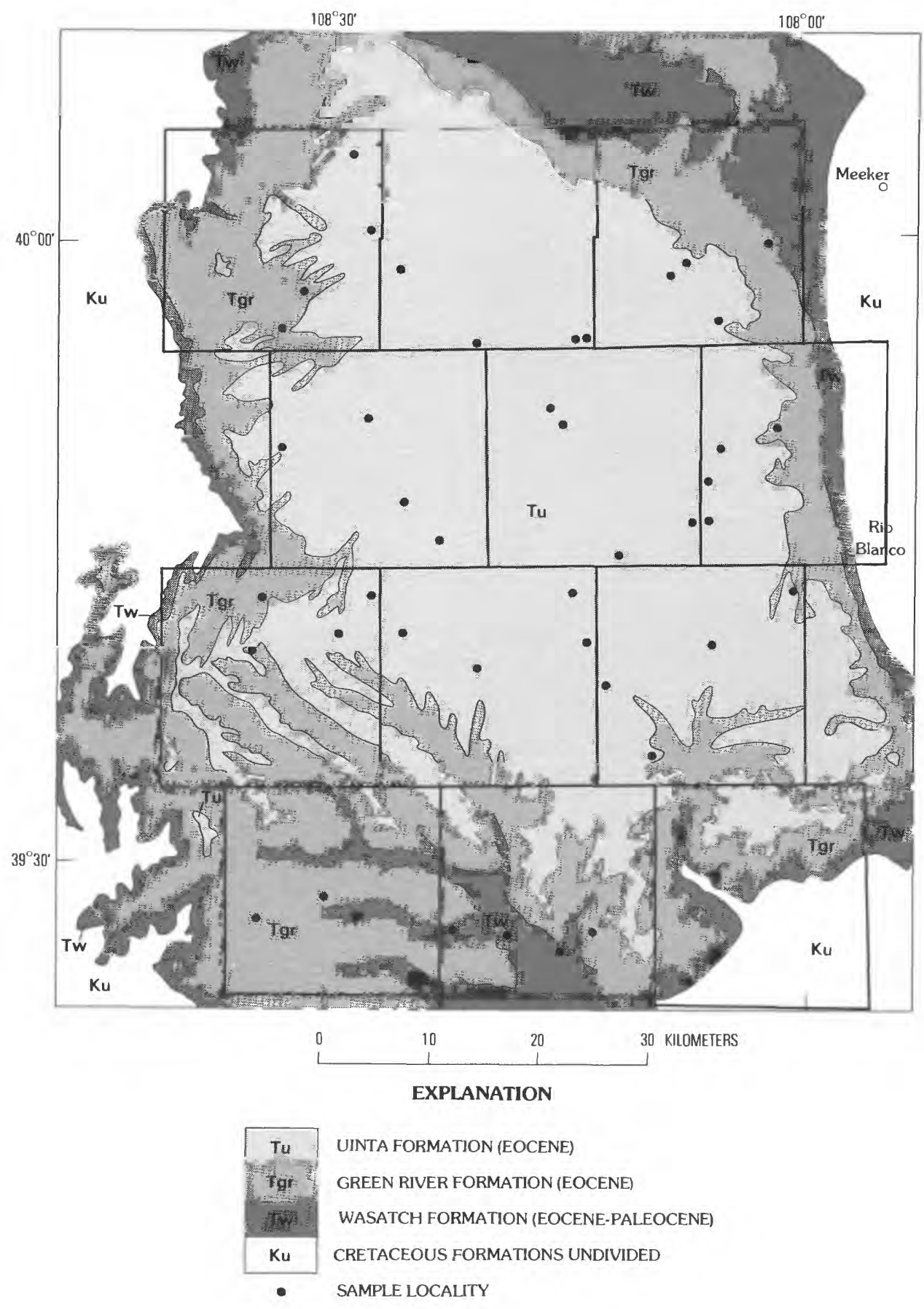

FIGURE 2.-Geologic map of Piceance basin (modified from Tweto, 1976) showing sample localities and supertownships (the heavily lined areas which are 19.3 kilometers on a side).

chosen for collection of two samples, 100 meters apart; only one sample was collected in the other section. This design resulted in 72 sample localities in 48 sections, but 1 sample locality was inaccessible resulting in a suite of 71 soil samples. From these, 12 samples were randomly chosen for duplicate analyses, thus producing an analytical level within the design. Big sagebrush and western wheatgrass were collected at 69 of these sites resulting in a total of 80 samples, including 12 duplicate analyses, for each of these two materials. 


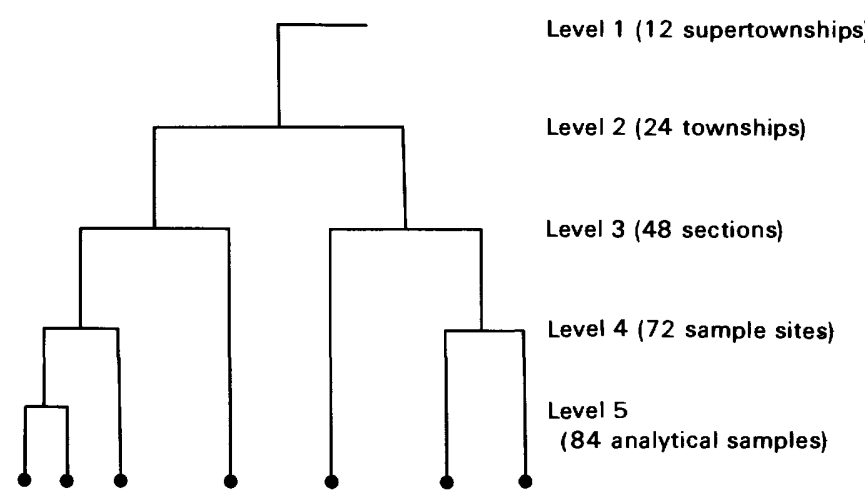

FiguRE 3.-Analysis-of-variance sampling design for soils and plants collected from Piceance basin.

\section{REVEGETATION PLOT STUDY}

An unbalanced, nested, analysis-of-variance design was used to determine what effect, if any, varying amounts of topsoil over spent oil shale (Paraho directretorted shale) had on the mobilitv of elements from spent oil shale into topsoil and plants. The design (fig. 4) consisted of three levels: (1) different depths of topsoil over spent oil shale in lysimeters $(0,20,40,60$, and 80 centimeters plus a control lysimeter containing only topsoil), (2) adjacent lysimeters containing the same depth of topsoil, and (3) analytical error. For each topsoil depth, three samples of topsoil material and western wheatgrass were collected-one associated with each of the two lysimeters with one randomly selected to be split as an analytical replicate. Only one lysimeter with no topsoil covering was sampled because of a limited amount of western wheatgrass growing in the lysimeter. A total of 17 soil samples and 17 western wheatgrass samples were collected.

\section{FIELD SAMPLING AND LABORATORY ANALYSIS}

The soil samples from each of the 71 sample localities within the basin were composites from areas about 10 meters in diameter ( 80 square meters). The samples of soil from the revegetation plot were composites from an area about one meter in diameter ( 0.8 square meters). All soil samples were collected from the surface to a depth of about five centimeters with a teflon spatula and placed in a paper sample bag. In the laboratory, the samples were air dried at room temperature, disaggregated in a soil grinder equipped with a ceramic mortar and a ceramic screw-type grinding head, passed through a 2-mm (10-mesh) stainless steel sieve, and split into analytical duplicates if necessary. A portion of the less than 2-mm fraction was further ground in a ceramic plate grinder to pass a $0.15-\mathrm{mm}$ (100-mesh) sieve. The 10-mesh fraction was used for $\mathrm{pH}$ and ex- tractable element determinations, and the 100-mesh fraction was used for total element and mineralogy determinations. Samples were submitted for analyses in a random sequence to convert any systematic sample preparation or analytical errors to random errors. Table 1 lists the methods of analysis for the various determinations made on each soil sample. Table 2 lists the two-theta peak positions for the minerals determined in the soil samples.

Sampling of plants was done in June 1979. Seasonal differences in plant maturity were minimized by sampling lower elevations first and higher elevations later in the month. Throughout the sampling period, western wheatgrass was in the "immature" stage. This stage is defined as the period between one-third and twothirds growth and before bloom (National Research Council, U.S., and Department of Agriculture, Canada, 1971). Big sagebrush was in the "rapid vegetative growth" stage characterized by new stem and leaf growth with reproductive shoots initiated (DePuit and Caldwell, 1973).

Plant samples were collected from, and composited over, the same area in which the soil samples were collected. Western wheatgrass was collected by cutting the plant near the ground with a stainless steel knife. The terminal 10 centimeters of big sagebrush growth was collected with pruning shears. The material collected was thought to represent current years growth and is the plant part most likely to be used as forage. Each plant sample was transported from the field to the laboratory in a cloth bag. Because of potential soil contamination from rain splash, the western wheatgrass samples were washed by rinsing the grass several times with tap water, followed by a final rinsing in distilled water. The plants were dried at $30^{\circ} \mathrm{C}$, ground in a Wiley mill to pass a $1.3-\mathrm{mm}$ screen, and split into analytical duplicates if necessary. The samples were randomly ordered prior to analysis. A part of the homogenized ground sample was then ashed by dry ignition at $500^{\circ} \mathrm{C}$ for 24 hours. Table 1 lists the methods of analysis for the various determinations made on each plant sample.

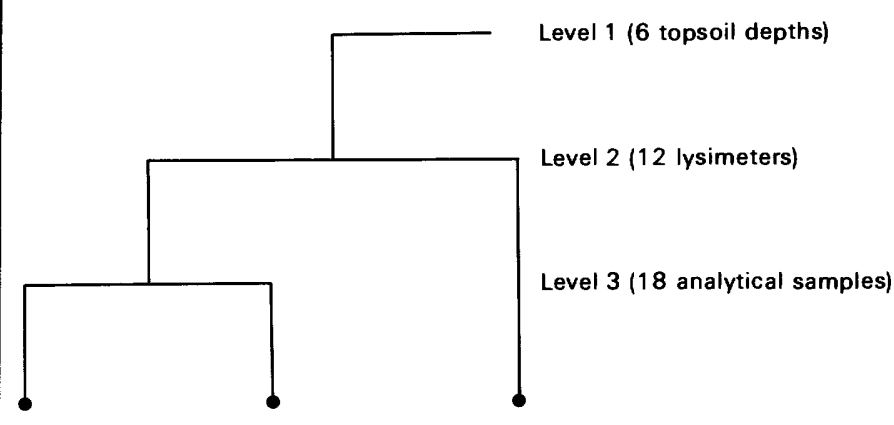

FIgURE 4.-Analysis-of-variance design for soils and western wheatgrass from Anvil Points experimental revegetation plot. 
TABLE 1.-Methods of analysis for geochemical properties of soils and biogeochemical properties of plants

\begin{tabular}{|c|c|}
\hline Methods & Properties \\
\hline \multicolumn{2}{|c|}{ Soils } \\
\hline $\mathrm{X}$-ray fluorescence ${ }^{1}$ & $\mathrm{Al}, \mathrm{Ca}, \mathrm{K}, \mathrm{Mg}, \mathrm{P}, \mathrm{Si}, \mathrm{Ti}$ \\
\hline $\begin{array}{l}\text { Enission spectroscopy }{ }^{2} \\
\text { (Argon-oxygen d-c arc) }\end{array}$ & $\begin{array}{l}\mathrm{Ba}, \mathrm{Be}, \mathrm{B}, \mathrm{Ce}, \mathrm{Cr}, \mathrm{Co}, \mathrm{Cu}, \mathrm{Fe}, \mathrm{Ga}, \\
\mathrm{La}, \mathrm{Mg}, \mathrm{Mn}, \mathrm{Mo}, \mathrm{Nb}, \mathrm{Ni}, \mathrm{Pb}, \mathrm{Sc}, \\
\mathrm{Sr}, \mathrm{V}, \mathrm{Y}, \mathrm{Yb}, \mathrm{Zn}, \mathrm{Zr}\end{array}$ \\
\hline Specific ion electrode 34 & $\mathrm{~F}, \mathrm{pH}$ \\
\hline Atomic absorption ${ }^{3}$ & $\mathrm{Li}, \mathrm{Na}$ \\
\hline$x$-ray diffraction 5 & Mineralogy \\
\hline $\begin{array}{l}\text { Emission spectroscopy } \\
\text { (Induction coupled argon plasma) }\end{array}$ & DTPA-extractable elements \\
\hline Gasometric ${ }^{3}$ & Total $\mathrm{C}$, Carbonate $\mathrm{C}$ \\
\hline Calculated & Organic C \\
\hline \multicolumn{2}{|c|}{ Plants } \\
\hline Loss on ignition ${ }^{7}$ & Ash percent \\
\hline $\begin{array}{l}\text { Enission spectroscopy } 8 \\
\text { (Induction coupled argon plasma) }\end{array}$ & $\begin{array}{l}\mathrm{A} 1, \mathrm{~B}, \mathrm{Ba}, \mathrm{Ca}, \mathrm{Fe}, \mathrm{Mg}, \mathrm{Mn}, \mathrm{Na}, \mathrm{Ni}, \mathrm{P}, \\
\mathrm{Sr}, \mathrm{V}\end{array}$ \\
\hline Atomic absorption ${ }^{7} 910$ & $\mathrm{Cd}, \mathrm{Cu}, \mathrm{Mo}, \mathrm{Zn}$ \\
\hline Specific ion electrode ${ }^{7}$ & $\mathrm{~F}$ \\
\hline $\begin{array}{l}1 \text { Taggert, Wahlberg, and Taylor } \\
2 \text { Dorrzapf (1973). } \\
3 \text { Huffinan and Dinnin (1976). } \\
4 \text { Peech (1965). } \\
5 \text { Schiltz (1964). } \\
6 \text { Soltanpour and Schwab (1977). } \\
7 \text { Harmes (1976). } \\
8 \text { Jones (1977). } \\
9 \text { Ward, Nakagawa, Harmes, and Va } \\
10 \text { Nakagawa, Watterson, and Nart }\end{array}$ & e $(1969)$ \\
\hline
\end{tabular}

Properties in some samples were below the limit of determination of the analytical method used-these values are referred to as being "censored." If less than 20 percent of the values for a property were below the limit of determination of the method, the censored values were replaced with a small number $(0.7$ times the lower limit of determination). These small number of replacements will not greatly alter the statistical tests or affect interpretation. Means and deviations for these properties were calculated using Cohen's method (1959) as described by Miesch (1967). If more than 20 percent of the values were censored, the property was omitted from the study.

\section{DATA EVALUATION ANALYSIS OF VARIANCE}

The analysis-of-variance model for the Basin Study is shown diagrammatically in figure 3 and can be written mathematically as follows:

$$
\chi_{i j k l m}=\mu+\alpha_{i}+\beta_{i j}+\gamma_{i j k}+\delta_{i j k l}+\epsilon_{i j k l m}
$$

where $\alpha$ represents supertownships, $\beta$ represents townships, $\gamma$ represents sections, $\delta$ represents sample sites, and $\epsilon$ represents analytical replicates. Each 
geochemical property determined in each sample $\left(\chi_{i k l m}\right)$ is represented by a grand regional mean, $\mu$ plus deviations related to each level of the design. The model partitions the total variance of the observed values into variance components associated with each level in the design (Miesch, 1976). If a $\log _{10}$-transformation is performed on the data $\left(\log \chi_{i j k l m}\right)$ the model partitions the logarithmic variance. The variance components are additive:

$$
s_{\chi}^{2}={s_{\alpha}}^{2}+s_{\beta}^{2}+s_{\gamma}^{2}+s_{\delta}^{2}+s_{\epsilon}^{2} \text {. }
$$

The variance components were calculated using a computer program written by VanTrump and Miesch (1977). A conventional $F$-test was used to determine statistical significance of each variance component at the 0.05 probability level. If the variance component at the supertownship level $\left(s_{\alpha}^{2}\right)$ is significant for an element or mineral, a map, based on supertownship means, might be the appropriate way to represent variation. For baselines of geochemical and biogeochemical properties which lack a significant variance component at the supertownship level, the variability is better represented by the overall mean and deviation for the entire basin.

Steps useful in determining the stability of geochemical and biogeochemical baseline maps for those parameters with significant variation at the supertownship level are outlined here. First, determine the minimum number of random samples that should be collected within each supertownship in order to distinguish compositional differences between any two supertownships ( $n_{r}$ of Miesch, 1976, p. A9). This number may be determined at an 80- or 95-percent confidence level from curves relating $n_{r}$ to the variance ratio $(v)$, calculated as shown by Miesch (1976, p. A8-A9):

$$
v=\frac{s_{\alpha}{ }^{2}}{s_{\beta}{ }^{2}+s_{\gamma}{ }^{2}+s_{\delta}{ }^{2}+s_{\epsilon}{ }^{2}} \text {. }
$$

Second, the maximum-acceptable-error variance $\left(E_{r}\right)$ of the means for supertownships is calculated from (Miesch, 1976):

$$
E_{r}=\frac{s_{\beta}^{2}+s_{\gamma}{ }^{2}+s_{\delta}^{2}+s_{\epsilon}{ }^{2}}{n_{r}}
$$

TABLE 2.-Two-theta position of $X$-rau diffraction peaks measured to determine relative abundances of minerais in soils

\begin{tabular}{ll} 
Mineral & $\begin{array}{c}\text { Peak Position } \\
\text { (degrees ? } \theta \text { ) }\end{array}$ \\
\hline Clay ninerals- & 20.0 \\
Analcine- & 26.0 \\
Quartz-. & 26.6 \\
Sodiun feldspar-- & 27.5 \\
Calcite- & 29.0 \\
Dolomite- & 29.5 \\
\hline
\end{tabular}

Third, the $E_{r}$ value is then compared to the observed error variance calculated as follows:

$$
E_{s}=\frac{s_{\beta}{ }^{2}}{n_{\beta}}+\frac{s_{\gamma}{ }^{2}}{n_{\beta} n_{\gamma}}+\frac{s_{\delta}{ }^{2}}{n_{\beta} n_{\gamma} n_{\delta}}+\frac{s_{\epsilon}{ }^{2}}{n_{\beta} n_{\gamma} n_{\delta} n_{\epsilon}},
$$

where subscripted $n$ 's represent the number of units in each level of the hierarchical design.

Because this study used an unbalanced design and the number of units in each level were not constant, it is necessary to calculate effective $n$ values using the technique described by Leone, Nelson, Johnson, and Eisenstat (1968). Since only a part of the available population with a particular level was sampled, finite population terms (as calculated by Cochran, 1963) were used to better approximate $E_{s}$. The $E_{s}$ equation used in this study, incorporating both finite population and effective- $n$ correction terms, was as follows:

$$
E_{s}=\frac{s_{\beta}^{2}}{3.92}+\frac{s_{\gamma}{ }^{2}}{3.36}+\frac{s_{\delta}^{2}}{5.44}+\frac{s_{\epsilon}^{2}}{7.00}
$$

Finally, map stability is assessed by the variance mean ratio $\left(v_{m}\right)$ calculated as follows (Miesch, 1976, $\mathrm{p}$. A10):

$$
v_{m}=\frac{s_{\alpha}^{2}}{E_{s}}
$$

If $v_{m}$ is one or greater, the variance among supertownships is at least equal to the variance within supertownships and map patterns based on supertownship means should be reproducible. As $v_{m}$ increases, the probability that a map pattern will be reproducible also increases. 
The statistical model for the Revegetation Plot Study, diagrammed in figure 4 , is similar to that for the Baseline Study; however, there are only three levels:

$$
\chi_{i j k}=\mu+\alpha_{i}+\beta_{i j}+\epsilon_{i j k},
$$

where $\alpha$ represents topsoil depths, $\beta$ represents lysimeters, and $\epsilon$ represents analytical error. The total variance is partitioned as follows:

$$
s_{X}^{2}=s_{\alpha}^{2}+s_{\beta}^{2}+s_{\epsilon}^{2}
$$

Again, the conventional $F$-test is used to determine the statistical significance of a variance component. Because $\alpha$ in this design does not represent a geographic variable, $v_{m}$ is irrelevant here.

\section{Q-MODE FACTOR ANALYSIS}

The factor analysis procedure used here is the CABFAC program described by Klovan and Imbrie (1971). This program groups individual samples with regard to similar multivariate characteristics. Factor loadings are assigned to each sample so that the sample can be viewed as a mixture of end-member samples. Endmember samples are those with the highest loading for each factor. Samples with high loadings for any factor are similar with regards to intercorrelated geochemical properties characterizing that factor and are, therefore, grouped together. Samples with low loadings for all factors are combined into an intermediate group which will be designated as Group 4. The spatial variation of factors can be used to identify which variables are most important in controlling geographic distribution of geochemical properties in soils and plants.

The number of factors used in the $Q$-mode factor model is arbitrary. A large number of factors generally makes interpretation difficult and too few factors may not explain a sufficient portion of the variance in the data. The $Q$-mode factor model in this study used three factors resulting in four groups of samples. Increasing the number of factors did not significantly increase the portion of the data variance explained by the model.

\section{MULTIPLE REGRESSION}

The plant uptake prediction equations were calculated by stepwise multiple regression using a computer program written by VanTrump and Miesch (1977) based on procedures described by Efroymson (1960).
The statistical model for multiple regression is given by

$$
Y=\hat{Y}+\epsilon
$$

where

$$
\hat{Y}=\beta_{0}+\beta_{1} X_{1}+\beta_{2} X_{2}+\ldots+\beta_{i} X_{i}
$$

In this model, $Y$ is the observed plant concentration, $\hat{Y}$ is the predicted plant concentration (dependent variable), the $X_{i}$ 's are statistically significant soil properties (independent variables), $\beta_{0}$ is the regression constant, $\beta_{i}$ 's are the regression coefficients, and $\epsilon$ is the difference between the actual plant content and the predicted value.

The percent of the total variance of $Y$ explained by the prediction $\left(r^{2} \times 100\right)$ was determined along with the relative importance of each independent variable in the equation as determined from the ratio of standard partial regression coefficients.

\section{RESULTS AND DISCUSSION BASIN STUDY}

\section{GEOCHEMICAL AND BIOGEOCHEMICAL VARIABILITY}

Results of geochemical and biogeochemical analyses are summarized in table 3. Frequency distributions, skewness, and kurtosis for most properties indicated that the data were best described by a log-normal distribution. Results of statistical tests for those properties determined to be best described by a normal distribution were the same whether untransformed or $\log _{10^{-}}$ transformed data were used. Therefore, all data, except $\mathrm{pH}$, were transformed to common logarithms. The $\mathrm{pH}$ data were not transformed because they are logarithmic measurements.

The estimates of variance components associated with each distance-related sampling interval are given in table 4. Variance components on a local scale (section and sample levels) are statistically significant for 76 of the 87 soil and plant properties. Nine properties have variance components that are significant at the township level, and 31 have variance components that are significant at the supertownship level. Baseline values for properties with 50 percent or more of their total variance at the analytical level (table 6) were not determined because the magnitude of analytical error is deemed excessive for examining the properties' distribution within the basin.

The analysis of variance results are a first approximation in determining the suitability of representing 
variation of soil or plant properties by maps. The geographic variation for most properties occurs within distances up to 10 kilometers. Some properties show significant variability for distances greater than 19 kilometers suggesting that regional processes are in part controlling the amounts of these constituents in soils and plants within the basin.

Parameters of map stability are given in table 5 . These parameters are used to determine if the sampling density in this study is sufficient to map regional trends within the basin. The parameter $n_{r}$ is the estimated number of random samples per supertownship needed to distinguish compositional differences of soils and plants in different supertownships. Properties with indefinitely large $n_{r}$ values are considered to be unmappable within the basin. The variance-mean ratio $\left(v_{m}\right)$ is a ratio of the variance among supertownships to the variance of the mean within supertownships. Table 6 groups soil and plant properties based on the variancemean ratio. A variance-mean ratio of less than 1.00 indicates that regional trends cannot be adequately mapped with the sampling density used. Baselines for 34 soil and plant properties with variance-mean ratios less than 1.00 are represented by the 95 -percent expected range given in table 3 . This range represents the limits within which 95 percent of the measured values for each property in soils and plants within the basin would be expected to occur.

Forty-seven properties have variance-mean ratios greater than or equal to 1.00. Regional maps for each of these soil and plant properties are given in figure 5. Baselines (95-percent expected range) for mappable properties for each supertownship can be calculated from the data in the Appendix. The range represents the limits within which 95 percent of the population values within a supertownship would be expected to occur.

As mentioned previously, the sampling design is a modification of a design used in a study of Piceance basin soils by Dean, Ringrose, and Klusman (1979). The major difference between the two designs is that this study included three additional supertownships. The two studies measured 32 common major and trace elements in basin soils. The reported geometric means (Dean and others, 1979) for most of these elements are similar to those reported in table 3. Dean, Ringrose, and Klusman found that most of the variability in soil composition occurs at the sample and section levels, and this is in agreement with the results shown in table 4. There is a discrepancy between the two studies regarding suitability of geochemical maps. Map stability was reproducible for only 64 percent of the 32 ele- ments. This seemingly low percentage may be due to the different sizes of the study areas, different analytical techniques, and chance (variance-mean ratios are only calculated at a 80-percent probability level).

\section{Q-MODE FACTOR ANALYSIS}

The geographic trends represented by the geochemical maps of soil properties (figs. $5 A$ to $5 C C$ ) can be grouped as to whether the values increase to the northern, southern, or central parts of the basin. Lithology of soil-parent material, climate, physiography, and hydrology are all variables in rock weathering and subsequent soil formation. The Wasatch and Green River Formations, lower elevation, and more arid conditions characterize the southern part of the basin. The center of the basin is at a higher elevation, has more precipitation, and is mostly underlain by the Uinta Formation. Most of the area between the basin's center and the White River is also underlain by the Uinta Formation, but this northern area is dryer and lower than the central part of the basin. Soil development in the three areas (southern, central, and northern) may reflect differences in any or all of these variables. For example, the concentration of zinc in soil is highest in the south (fig. $5 N$ ). The increase may be due to higher zinc concentrations in the Wasatch Formation, low elevation, arid conditions, and (or) debris from the cliffs of the Green River Formation that rise above the southern part of the basin. The influence of these variables collectively was examined using $Q$-mode factor analysis.

A three-factor $Q$-mode model defines four geochemically different soil groups. Table 7 summarizes the composition of the samples for each of the four groups. Samples with high loadings for Factor 1 (Group 1) are from the elevated central part of the basin, along the rim of the Roan Cliffs (fig. 6A). Most samples are from ridgetop sites where the soil is derived from Uinta or Green River parent material. The elevated sodium and potassium contents in these samples (table 7) are probably due to feldspars which make up 10-30 percent of the rock. Organic carbon is enriched in the Green River oil shales; however, the organic matter important to this factor is that associated with recent vegetative debris in the soil. Field observations verify the increase in this latter source of organic matter with increasing elevation. Most DTPA-extractable elements are highly correlated with organic matter and are rich in these samples. The geochemical maps for sodium, organic carbon, sodium feldspar, and DTPA-extractable elements (fig. 5) substantiate high values for these soil properties along the rim of the Roan Cliffs. 
TABLE 3.-Summary statistics for geochemical properties of 83 soil samples, and biogeochemical properties of 80 big sagebrush samples, and 80 western wheatgrass samples collected from Piceance basin

[Plant variables are reported on a dry weight basis. $n$, number of samples which contained concentrations above the lower limit of determination of the analytical method; pet, percent; ppm, parts per million; pk ht, peak height; expected 95-percent range, the range within which 95 percent of the population would be expected to occur]

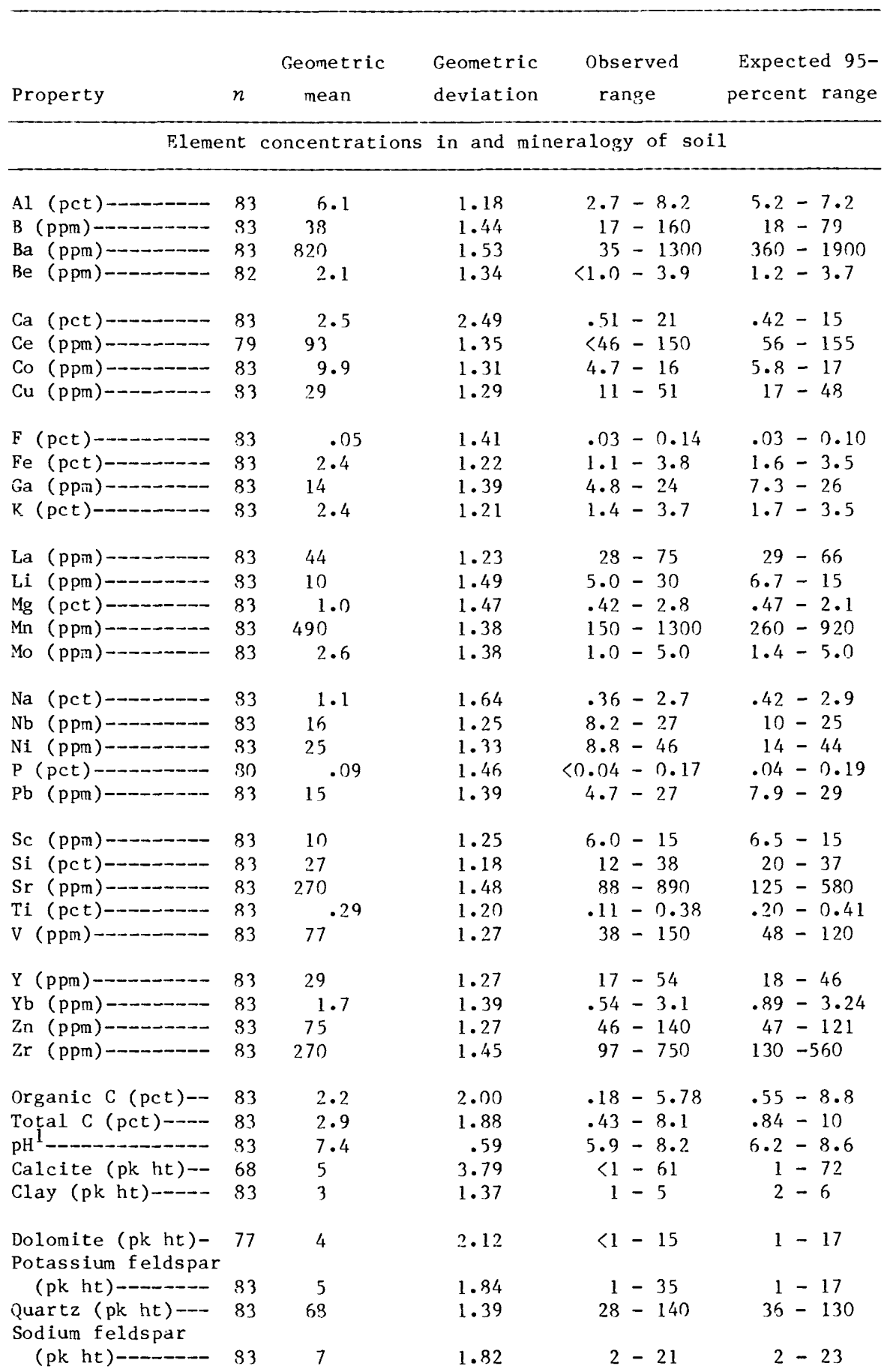


TABLE 3.-Summary statistics for geochemical properties of 88 soil samples, and biogeochemical properties of $80 \mathrm{big}$ sagebrush samples, and 80 western wheatgrass samples collected from Piceance basin-Continued

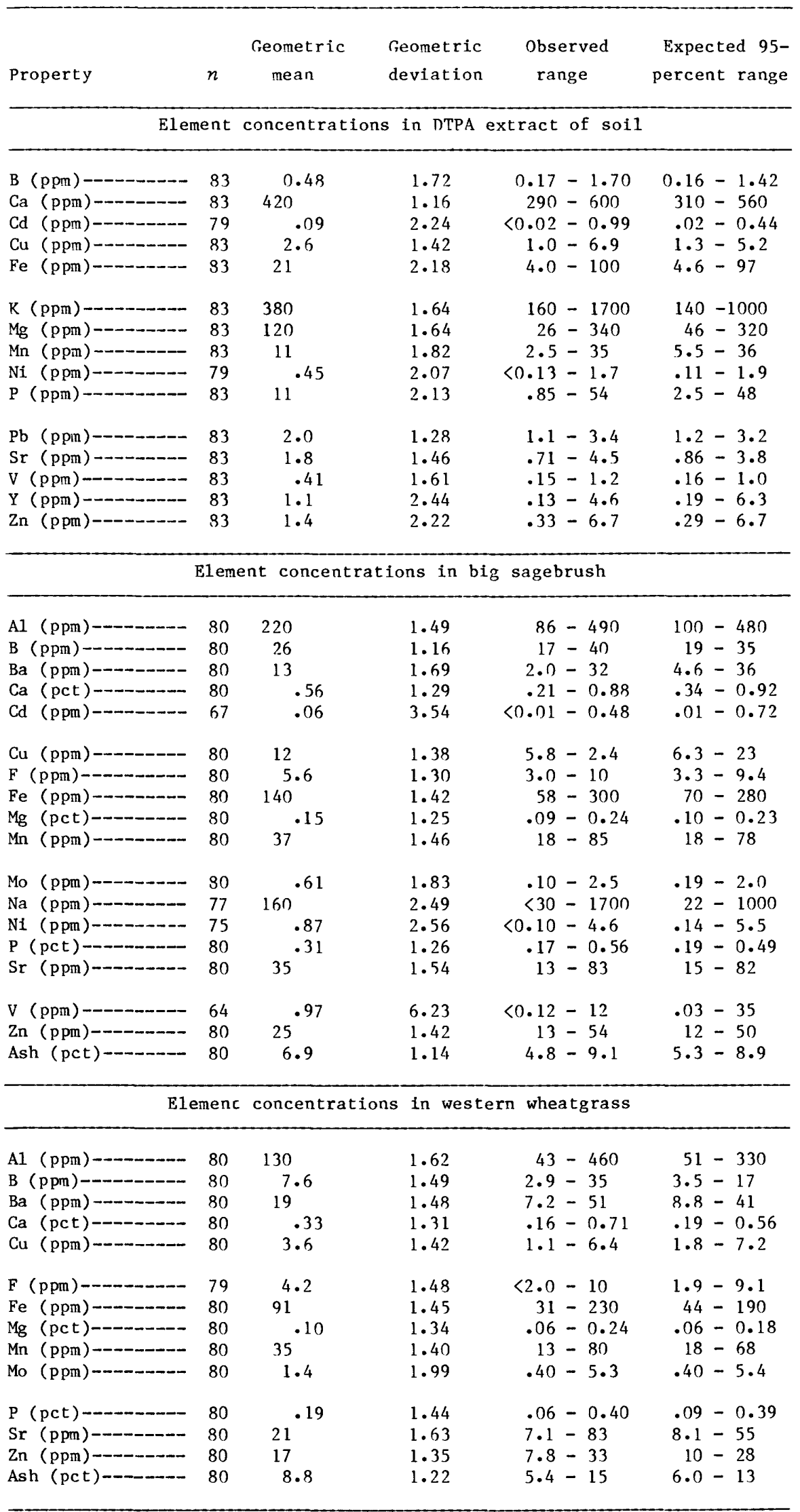

$1_{\text {Arithmetic mean and deviation. }}$ 
TABLE 4.-Total logarithmic variance and variance components, as percentage of the total variance, for geochemical properties of 83 soil samples, and biogeochemical properties of 80 big sagebrush samples and 80 western wheatgrass samples from the Piceance basin

[Distances are average distances between randomly selected sample sites within levels]

\begin{tabular}{|c|c|c|c|c|c|c|}
\hline \multirow[b]{2}{*}{ Property } & \multirow[b]{2}{*}{$\begin{array}{l}\text { Total } \\
\text { logarithmic } \\
\text { variance }\end{array}$} & \multicolumn{5}{|c|}{ Variance component as percentage of total variance } \\
\hline & & $\begin{array}{c}\text { Among } \\
\text { supertownships } \\
(>19 \mathrm{~km})\end{array}$ & $\begin{array}{l}\text { Among } \\
\text { townships } \\
(10-19 \mathrm{~km})\end{array}$ & $\begin{array}{c}\text { Among } \\
\text { sections } \\
(1.2-10 \mathrm{~km})\end{array}$ & $\begin{array}{l}\text { Among } \\
\text { samples } \\
(100 \mathrm{~m})\end{array}$ & $\begin{array}{l}\text { Among } \\
\text { analyses }\end{array}$ \\
\hline \multicolumn{7}{|c|}{ Elements in and mineralogy of soil } \\
\hline $\mathrm{Al}=--\infty-\infty$ & 0.0079 & $1_{21}$ & 0 & $1_{52}$ & $1_{27}$ & 0 \\
\hline B---------- & .0272 & 0 & 13 & 36 & 142 & 9 \\
\hline $\mathrm{Ba}-\infty+\infty \rightarrow+\infty$ & .0842 & 0 & ${ }^{1} 12$ & 0 & 0 & 88 \\
\hline Be---n- & .0257 & 7 & 0 & 170 & 2 & 21 \\
\hline $\mathrm{Ca}-\cdots+-\infty+\infty$ & .1603 & 6 & 0 & $1_{76}$ & ${ }_{18}$ & 0 \\
\hline Ce---_--_-- & .0413 & 7 & 0 & $1_{49}$ & 0 & 44 \\
\hline Co--_-n--n & .0184 & 140 & 0 & $1_{43}$ & 9 & 8 \\
\hline Cu- & .0130 & ${ }^{1} 30$ & 0 & 17 & 19 & 34 \\
\hline F-1--1- & .0231 & 10 & 9 & $1_{55}$ & $1_{22}$ & 4 \\
\hline $\mathrm{Fe}-\cdots+-$ & .0086 & $1_{54}$ & 0 & $1_{26}$ & $1_{20}$ & 0 \\
\hline Ga-n-mon & .0259 & 12 & 0 & $1_{45}$ & $1_{35}$ & 8 \\
\hline K--- & $.0 \cap 79$ & 14 & 0 & 159 & $1_{27}$ & 0 \\
\hline La---_-_-_- & .0094 & 14 & 0 & $1_{53}$ & 4 & 29 \\
\hline Li-_-_-_-_- & .0305 & 17 & 4 & 28 & $1_{39}$ & 12 \\
\hline Yg- - & .0321 & 8 & 0 & 179 & 13 & 0 \\
\hline Mn---n-- & .0197 & 29 & 7 & $1_{44}$ & 112 & 8 \\
\hline Mo---_----- & .0246 & 4 & 0 & 21 & $1_{59}$ & 16 \\
\hline $\mathrm{Na}--------$ & .0483 & ${ }^{1} 37$ & ก & 154 & $i_{9}$ & ก \\
\hline Nb- & .0164 & 0 & 0 & $1_{65}$ & 0 & 35 \\
\hline Ni-O-O-- & .0198 & $1_{37}$ & $n$ & 141 & ${ }^{1} 14$ & 3 \\
\hline 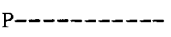 & .0306 & 21 & 135 & $n$ & 140 & 4 \\
\hline Pb-------- & .0289 & 117 & 0 & $1_{65}$ & 8 & 9 \\
\hline Sc---_- - - & .0121 & 134 & 0 & 149 & 4 & 13 \\
\hline Si----- & $.0 \cap 70$ & 11 & 0 & 173 & ${ }^{1} 16$ & 0 \\
\hline Sr--non & .0332 & 5 & 0 & $1_{61}$ & 22 & 12 \\
\hline Ti-- & .0085 & $1_{43}$ & 0 & 140 & ${ }_{17}$ & 0 \\
\hline V-D & .0117 & $1_{54}$ & 0 & 121 & ${ }^{1} 15$ & 10 \\
\hline 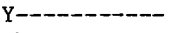 & .0112 & 28 & 2 & 135 & 17 & 18 \\
\hline 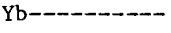 & .0253 & 16 & 0 & 154 & $1_{20}$ & 10 \\
\hline Zn- - & .0146 & $1_{30}$ & 0 & $1_{52}$ & 7 & 11 \\
\hline Zr---C- & .0290 & 4 & 0 & 60 & 16 & 20 \\
\hline Organic C--- & .0975 & $1_{61}$ & 0 & 126 & 111 & 2 \\
\hline Toţal C- & .0863 & $1_{34}$ & 0 & 155 & ${ }^{1} 11$ & 0 \\
\hline $\mathrm{pH}^{2}-\cdots$ & .4284 & ${ }^{1} 37$ & 0 & $1_{48}$ & 5 & 10 \\
\hline Calcite- & 1.8396 & 12 & 0 & ${ }^{1} 72$ & $n$ & 16 \\
\hline Clay------- & .0219 & $1_{43}$ & 0 & $1_{31}$ & $n$ & 26 \\
\hline Dolomi te---- & .5962 & $\mathrm{l}_{23}$ & $n$ & $1_{38}$ & 6 & 33 \\
\hline Potassium & & & & & & \\
\hline feldspar--- & .0913 & 0 & 0 & 166 & 15 & 19 \\
\hline Quartz- & .0209 & 5 & 7 & $1_{67}$ & 8 & 13 \\
\hline Sodium & & & & & & \\
\hline feldspar--- & .0856 & $1_{27}$ & 0 & $\mathrm{I}_{36}$ & 12 & 25 \\
\hline
\end{tabular}


TABLE 4.-Total logarithmic variance and variance components, as percentage of the total variance, for geochemical properties of 83 soil samples, and biogeochemical properties of 80 big sagebrush samples and 80 western wheatgrass samples from the Piceance basin-Continued

\begin{tabular}{|c|c|c|c|c|c|c|}
\hline \multirow[b]{2}{*}{ Property } & \multirow[b]{2}{*}{$\begin{array}{l}\text { Total } \\
\text { logarithmic } \\
\text { variance }\end{array}$} & \multicolumn{5}{|c|}{ Variance component as percentage of total variance } \\
\hline & & $\begin{array}{c}\text { Among } \\
\text { supertownships } \\
(>19 \mathrm{~km})\end{array}$ & $\begin{array}{l}\text { Among } \\
\text { townships } \\
(10-19 \mathrm{~km})\end{array}$ & $\begin{array}{c}\text { Among } \\
\text { sections } \\
(1.2-10 \mathrm{~km})\end{array}$ & $\begin{array}{c}\text { Among } \\
\text { samples } \\
(100 \mathrm{~m})\end{array}$ & $\begin{array}{l}\text { Among } \\
\text { analyses }\end{array}$ \\
\hline \multicolumn{7}{|c|}{ Elements in DTPA extract of soil } \\
\hline 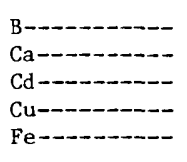 & $\begin{array}{r}0.0664 \\
.0042 \\
.1248 \\
.0266 \\
.1205\end{array}$ & $\begin{array}{r}4 \\
27 \\
132 \\
7 \\
164\end{array}$ & $\begin{array}{r}0 \\
0 \\
12 \\
0 \\
1_{14}\end{array}$ & $\begin{array}{r}1_{40} \\
1_{37} \\
9 \\
1_{50} \\
1_{16}\end{array}$ & $\begin{array}{r}0 \\
12 \\
18 \\
139 \\
1 / 4\end{array}$ & $\begin{array}{r}56 \\
24 \\
29 \\
4 \\
2\end{array}$ \\
\hline 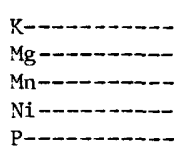 & $\begin{array}{l}.0531 \\
.0583 \\
.0748 \\
.0978 \\
.1215\end{array}$ & $\begin{array}{r}22 \\
14 \\
142 \\
150 \\
159\end{array}$ & $\begin{array}{l}0 \\
0 \\
0 \\
5 \\
0\end{array}$ & $\begin{array}{l}154 \\
173 \\
146 \\
15 \\
125\end{array}$ & $\begin{array}{r}1_{22} \\
1_{11} \\
1_{9} \\
5 \\
1_{12}\end{array}$ & $\begin{array}{r}2 \\
2 \\
3 \\
25 \\
4\end{array}$ \\
\hline 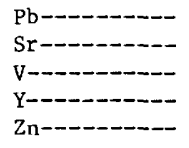 & $\begin{array}{l}.0134 \\
.0282 \\
.0465 \\
.1553 \\
.1257\end{array}$ & $\begin{array}{r}0 \\
15 \\
0 \\
134 \\
138\end{array}$ & $\begin{array}{r}18 \\
137 \\
0 \\
6 \\
5\end{array}$ & $\begin{array}{l}29 \\
18 \\
165 \\
141 \\
116\end{array}$ & $\begin{array}{l}16 \\
127 \\
16 \\
117 \\
119 \\
19\end{array}$ & $\begin{array}{r}37 \\
3 \\
19 \\
2 \\
2\end{array}$ \\
\hline \multicolumn{7}{|c|}{ Elements in big sagebrush } \\
\hline 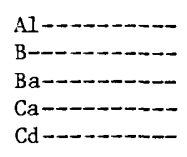 & $\begin{array}{r}0.0322 \\
.0520 \\
.0744 \\
.0123 \\
.4154\end{array}$ & $\begin{array}{r}0 \\
0 \\
136 \\
20 \\
0\end{array}$ & $\begin{array}{r}137 \\
2 \\
0 \\
8 \\
125\end{array}$ & $\begin{array}{r}10 \\
151 \\
145 \\
9 \\
0\end{array}$ & $\begin{array}{l}145 \\
131 \\
117 \\
146 \\
163\end{array}$ & $\begin{array}{r}8 \\
16 \\
2 \\
17 \\
12\end{array}$ \\
\hline $\begin{array}{l}\mathrm{Cu}-\cdots \\
\mathrm{F}- \\
\mathrm{Fe}- \\
\mathrm{Mg}-\end{array}$ & $\begin{array}{l}.0249 \\
.0154 \\
.0233 \\
.0100 \\
.0281\end{array}$ & $\begin{array}{r}135 \\
0 \\
4 \\
149 \\
18\end{array}$ & $\begin{array}{r}0 \\
21 \\
25 \\
0 \\
18\end{array}$ & $\begin{array}{r}24 \\
0 \\
14 \\
122 \\
1_{40}\end{array}$ & $\begin{array}{r}137 \\
36 \\
143 \\
7 \\
21\end{array}$ & $\begin{array}{r}4 \\
43 \\
15 \\
22 \\
3\end{array}$ \\
\hline 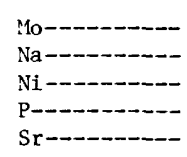 & $\begin{array}{l}.0708 \\
.1981 \\
.3536 \\
.0153 \\
.0371\end{array}$ & $\begin{array}{r}135 \\
143 \\
0 \\
0 \\
143\end{array}$ & $\begin{array}{r}7 \\
0 \\
6 \\
125 \\
0\end{array}$ & $\begin{array}{r}1_{34} \\
1_{25} \\
2 \\
0 \\
135\end{array}$ & $\begin{array}{r}1_{14} \\
1_{22} \\
0 \\
0 \\
1_{19}\end{array}$ & $\begin{array}{r}10 \\
10 \\
92 \\
75 \\
3\end{array}$ \\
\hline 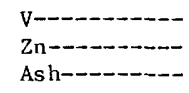 & $\begin{array}{l}.8334 \\
.0238 \\
.0002\end{array}$ & $\begin{array}{r}9 \\
24 \\
150\end{array}$ & $\begin{array}{r}12 \\
7 \\
1\end{array}$ & $\begin{array}{r}0 \\
133 \\
136\end{array}$ & $\begin{array}{r}0 \\
132 \\
7\end{array}$ & $\begin{array}{r}79 \\
4 \\
6\end{array}$ \\
\hline \multicolumn{7}{|c|}{ Elements in western wheatgrass } \\
\hline 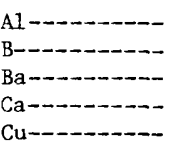 & $\begin{array}{r}0.0477 \\
.0360 \\
.0362 \\
.0161 \\
.0368\end{array}$ & $\begin{array}{r}11 \\
130 \\
126 \\
1_{26} \\
0\end{array}$ & $\begin{array}{l}n \\
0 \\
0 \\
0 \\
0\end{array}$ & $\begin{array}{r}1_{51} \\
1_{41} \\
0 \\
22 \\
1_{89}\end{array}$ & $\begin{array}{r}19 \\
14 \\
166 \\
136 \\
2\end{array}$ & $\begin{array}{r}19 \\
15 \\
8 \\
16 \\
9\end{array}$ \\
\hline 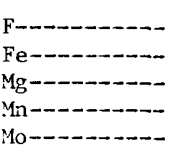 & $\begin{array}{l}.0293 \\
.0261 \\
.0182 \\
.0221 \\
.0924\end{array}$ & $\begin{array}{r}1_{28} \\
0 \\
1_{30} \\
25 \\
29\end{array}$ & $\begin{array}{r}4 \\
5 \\
0 \\
12 \\
128\end{array}$ & $\begin{array}{r}2 \\
133 \\
131 \\
131 \\
17\end{array}$ & $\begin{array}{r}0 \\
154 \\
19 \\
123 \\
122\end{array}$ & $\begin{array}{r}66 \\
8 \\
20 \\
9 \\
4\end{array}$ \\
\hline 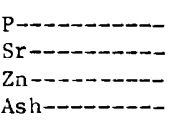 & $\begin{array}{l}.0254 \\
.0484 \\
.0178 \\
.0085\end{array}$ & $\begin{array}{r}6 \\
152 \\
24 \\
161\end{array}$ & $\begin{array}{r}149 \\
0 \\
0 \\
0\end{array}$ & $\begin{array}{l}1_{2}^{4} \\
1_{47} \\
1_{20}\end{array}$ & $\begin{array}{l}126 \\
10 \\
122 \\
117\end{array}$ & $\begin{array}{r}15 \\
16 \\
7 \\
2\end{array}$ \\
\hline
\end{tabular}

Lignificantly different at 0.05 probability level.

2 Total arithmetic variance. 
TABLE 5.-Calculated parameters used in estimating stability of maps based on the mean amounts of geochemical properties of soils and biogeochemical properties of plants within supertownships, Piceance basin

[ $v$, variance ratio; $n_{r}(80)$, number of random samples required within a supertownship to distinguish compositional differences between supertownships at the 80 percent confidence level; $E_{r}$, maximum acceptable error variance for supertownehip means; $E_{s}$, observed error variance for supertownship means; $v_{\mathrm{m}}$ variance mean ratio; -- means $n_{r}$ is indefinately large]

\begin{tabular}{|c|c|c|c|c|c|}
\hline Property & $v$ & $n_{r} \quad(80)$ & $E_{r}$ & $E_{s}$ & $v_{m}$ \\
\hline \multicolumn{6}{|c|}{ Elements in and mineralogy of soi 1} \\
\hline $\mathrm{A} 1-\cdots+\cdots+\infty-\infty \cdots$ & 0.27 & 5 & 0.0012 & 0.0009 & 1.79 \\
\hline B-- - - - - - - - - - & 0 & -- & -- & --- & --- \\
\hline $\mathrm{Ba}-$ & 0 & -- & -- & -- & -- \\
\hline $\mathrm{Be}-\mathrm{C}$ & .08 & 10 & .0024 & .0045 & .41 \\
\hline $\mathrm{Ca}-\cdots+\cdots+\infty-\infty+\cdots$ & .07 & 14 & .0107 & .0413 & .24 \\
\hline 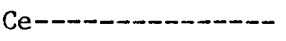 & .07 & 14 & .0028 & .0043 & .64 \\
\hline 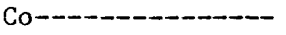 & .68 & 3 & .0037 & .0018 & $4 \cdot 10$ \\
\hline $\mathrm{Cu}$ & .47 & 3 & .0028 & .0015 & 2.52 \\
\hline F-m & .11 & 8 & .0026 & .0054 & .42 \\
\hline 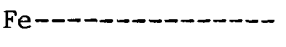 & 1.15 & 3 & .0013 & .0008 & 6.04 \\
\hline 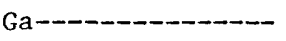 & .14 & 7 & .0033 & .0040 & .78 \\
\hline K--1-O- & .17 & 6 & .0011 & .0020 & .56 \\
\hline La-- - & .16 & 6 & .0013 & .0016 & .79 \\
\hline Li-C-1- & .21 & 5 & .0050 & .0055 & .95 \\
\hline Mg - - - - - & .09 & 9 & .0033 & .0074 & .35 \\
\hline 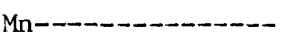 & .41 & 4 & .0035 & .0036 & 1.60 \\
\hline 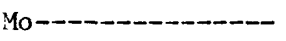 & .06 & 14 & .0013 & .0035 & .31 \\
\hline 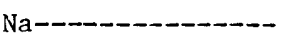 & .59 & 3 & .0101 & .0085 & 2.11 \\
\hline $\mathrm{Nb}-\infty-\infty$ & 0 & -- & -- & - & -- \\
\hline $\mathrm{Ni}-\cdots+-\infty-\infty$ & .58 & 3 & .0042 & .0021 & 3.56 \\
\hline $\mathrm{P}-1+\infty$ & .26 & 5 & .0048 & .0048 & 1.33 \\
\hline $\mathrm{Pb}-1+$ & .20 & 5 & .0048 & .0045 & 1.08 \\
\hline Sc- & .49 & 3 & .0027 & .0014 & 2.85 \\
\hline Si-C- & .12 & 7 & .0009 & .0013 & .57 \\
\hline Sr-- & .05 & 15 & .0021 & .0070 & .23 \\
\hline $\mathrm{Ti}-\cdots+\cdots$ & .76 & 3 & .0016 & .0007 & 5.08 \\
\hline V-C-C-C- & 1.19 & 3 & .0018 & .0012 & 5.39 \\
\hline Y-D- & .39 & 4 & .0020 & .0019 & 1.70 \\
\hline $\mathrm{Yb}-1+$ & .19 & 5 & .0042 & .0043 & .96 \\
\hline Zn- - - & .65 & 3 & .0021 & .0018 & 2.45 \\
\hline Zr-- & .05 & 15 & .0018 & .0053 & .20 \\
\hline Organic C-- & 1.63 & 2 & .0181 & .0093 & 6.38 \\
\hline Total C--_-_- & • 52 & 3 & .0190 & .0136 & 2.16 \\
\hline pH-- & .77 & 3 & .0674 & .0539 & 2.90 \\
\hline Calcite-_-_- & .17 & 6 & .2113 & . 3512 & .63 \\
\hline Clay----------- & 1.00 & 3 & .0032 & .0021 & 4.56 \\
\hline Dolomite-_- & .37 & 4 & .1095 & .0767 & 2.12 \\
\hline \multicolumn{6}{|l|}{ Potassium } \\
\hline feldspar------- & 0 & -- & -- & -- & -- \\
\hline Quartz-- & .05 & 19 & .0009 & .0052 & .17 \\
\hline \multicolumn{6}{|l|}{ Sodium } \\
\hline feldspar-- & .48 & 3 & .0156 & .0101 & 2.25 \\
\hline
\end{tabular}


TABLE 5.-Calculated parameters used in estimating stability of maps based on the mean amounts of geochemical properties of soils and biogeochemical properties of plants within supertownships, Piceance basin-Continued

\begin{tabular}{|c|c|c|c|c|c|}
\hline Property & $v$ & $n_{r} \quad(80)$ & $E_{r}$ & $E_{s}$ & $v_{m}$ \\
\hline \multicolumn{6}{|c|}{ Elements in DTPA extract of soil } \\
\hline B-D- & 0.05 & 16 & 0.0033 & 0.0107 & 0.23 \\
\hline 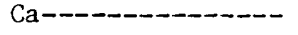 & .34 & 4 & .0008 & .0007 & 1.57 \\
\hline Cd-O-D-D- & .46 & 3 & .0285 & .0167 & 2.35 \\
\hline 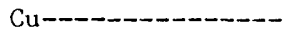 & .09 & 10 & .0021 & .0051 & .38 \\
\hline Fe-- - - - - & 1.82 & 2 & .0214 & .0111 & 6.98 \\
\hline K--- - - - - - - - - & .28 & 4 & .0104 & .0093 & 1.24 \\
\hline $\operatorname{sg} \cdots$ & .21 & 5 & .0078 & .0112 & .72 \\
\hline 纤- - - & .73 & 3 & .0144 & .0108 & 2.92 \\
\hline 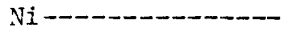 & .99 & 3 & .0164 & .0100 & 4.84 \\
\hline 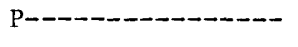 & 1.43 & 2 & .0250 & .0104 & 6.86 \\
\hline 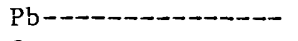 & 0 & -- & -- & -- & -- \\
\hline $\mathrm{Sr} \rightarrow-\infty+\cdots$ & .18 & 5 & .0048 & .0057 & .74 \\
\hline V-an- & 0 & -- & -- & -- & -- \\
\hline 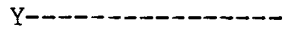 & .52 & 3 & .0341 & .0265 & 2.00 \\
\hline $\mathrm{Zn}-\cdots-\cdots-\infty-\infty$ & 1.39 & $?$ & .0263 & .0123 & 5.96 \\
\hline \multicolumn{6}{|c|}{ Elements in big sagebrush } \\
\hline $\mathrm{Al}+\ldots$ & 0 & $\ldots$ & -- & -- & -- \\
\hline B---n- - - - - - - & 0 & -- & --- & -- & --- \\
\hline $\mathrm{Ba}-\cdots$ & .57 & 3 & 0.0158 & 0.0073 & 3.71 \\
\hline $\mathrm{Ca}-\longrightarrow-1$ & .26 & 5 & .0020 & .0019 & 1.32 \\
\hline $\mathrm{Cd}-\cdots$ & 0 & -- & $-\infty$ & -- & -- \\
\hline 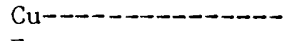 & .73 & 3 & .0039 & .0025 & 3.42 \\
\hline F-ー- - & 0 & $-\infty$ & -- & --- & -- \\
\hline Fe---D-C- & .05 & 15 & .0015 & .0047 & .22 \\
\hline $\mathrm{Mg}---$ & .95 & 3 & .0017 & .0011 & 4.45 \\
\hline Mn----n-- - & .22 & 5 & .0046 & .0058 & .89 \\
\hline 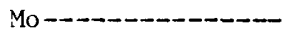 & .53 & 3 & .0154 & .0112 & 2.19 \\
\hline $\mathrm{Na}-\mathrm{O}$ & .74 & 3 & .0379 & .0223 & 3.78 \\
\hline $\mathrm{Ni}-\cdots$ & 0 & -- & -- & -- & -- \\
\hline 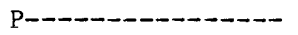 & 0 & -- & -- & $\infty$ & -- \\
\hline Sr-m-n--n-- & .75 & 3 & .0071 & .0053 & 3.00 \\
\hline V--1- & .10 & 8 & .0947 & .1834 & .41 \\
\hline $\mathrm{Zn}-\cdots-\cdots$ & .31 & 4 & .0045 & .0043 & 1.32 \\
\hline Ash-n-n-n- & 1.71 & 3 & .0006 & .0004 & 3.86 \\
\hline \multicolumn{6}{|c|}{ Elements in western wheatgrass } \\
\hline $\mathrm{Al}-\infty$ & 0.12 & 7 & 0.0061 & 0.0095 & 0.53 \\
\hline 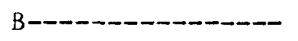 & .43 & 4 & .0063 & .0048 & 2.21 \\
\hline Ва- & .35 & 4 & .0067 & .0030 & 3.16 \\
\hline Ca-- & .36 & 4 & .0030 & .0025 & 1.70 \\
\hline $\mathrm{Cu}-\boldsymbol{n}$ & 0 & -- & --- & -- & --- \\
\hline F- & .38 & 4 & .0053 & .0030 & 2.67 \\
\hline $\mathrm{Fe}-\mathrm{C}$ & 0 & $\ldots$ & -- & -- & $\ldots$ \\
\hline 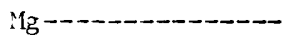 & .42 & 4 & .0032 & .0028 & 1.90 \\
\hline $\mathrm{Mn}-+-1-1-$ & .34 & 4 & .0041 & .0039 & 1.42 \\
\hline Mo--- & .41 & 4 & .0164 & .0156 & 1.71 \\
\hline P-m- & .07 & 14 & .0017 & .0052 & .32 \\
\hline $\mathrm{Sr}$ & 1.10 & 3 & .0077 & .0048 & 5.34 \\
\hline $\mathrm{Zn} \rightarrow-\cdots+\cdots-\cdots$ & .31 & 4 & .0034 & .0032 & 1.32 \\
\hline Ash-_ & .43 & 3 & .0034 & .0049 & 2.21 \\
\hline
\end{tabular}


TABLE 6.-Grouping of properties of Piceance basin soil and plant samples based on variance-mean ratios $\left(\mathrm{v}_{\mathrm{m}}\right)$ and analytical error variance $\left(\mathrm{S}_{\mathrm{e}}{ }^{2}\right)$

\begin{tabular}{ll}
\hline$v_{m}>1.00$ & $v_{m}<1.00 \quad s_{\varepsilon}{ }^{2}>50$ percent \\
\hline
\end{tabular}

Elements in and mineralogy of soil

\begin{tabular}{|c|c|c|}
\hline $\begin{array}{l}\text { Al, Co, Cu, Fe, Mn, Na, } \\
\text { Ni, P, Pb, Sc, Ti, V, } \\
\text { Y, Zn, Organic C, } \\
\text { Total Carbon, pH, } \\
\text { Clay, Dolomite, } \\
\text { Sodium feldspar }\end{array}$ & $\begin{array}{l}\text { B, Be, Ca, Ce, F, Ga } \\
\text { K, La, Li, Mg, Mo, Nh, } \\
\text { Si, Sr, Yb, Zr, Calcite } \\
\text { Potassium feldspar, } \\
\text { Quartz }\end{array}$ & $\mathrm{Ba}$ \\
\hline \multicolumn{3}{|c|}{ Elements in DTPA extract of soil } \\
\hline $\begin{array}{l}\mathrm{Ca}, \mathrm{Cd}, \mathrm{Fe}, \mathrm{K}, \mathrm{Mn}, \\
\mathrm{Ni}, \mathrm{P}, \mathrm{Y}, \mathrm{Zn}\end{array}$ & $\mathrm{Cu}, \mathrm{Mg}, \mathrm{Pb}, \mathrm{Sr}, \mathrm{V}$ & $B$ \\
\hline \multicolumn{3}{|c|}{ Elements in big sagebrush } \\
\hline $\begin{array}{l}\mathrm{Ba}, \mathrm{Ca}, \mathrm{Cu}, \mathrm{Ma}, \mathrm{Mo} \\
\mathrm{Na}, \mathrm{Sr}, \mathrm{Zn}, \mathrm{Ash}\end{array}$ & $\mathrm{Al}, \mathrm{B}, \mathrm{Cd}, \mathrm{F}, \mathrm{Fe}, \mathrm{Mn}$ & $\mathrm{Ni}, \mathrm{P}, \mathrm{V}$ \\
\hline \multicolumn{3}{|c|}{ Elements in western wheatarass } \\
\hline $\begin{array}{l}\text { B, Ba, Ca, Mq, Mn, } \\
\text { Mo, Sr, Zn, Ash }\end{array}$ & $\mathrm{Al}, \mathrm{Cu}, \mathrm{Fe}, \mathrm{P}$ & F \\
\hline
\end{tabular}

Samples with high loadings for Factor 2 (Group 2) are concentrated in the southwestern corner and scattered across the northern part of the basin (fig. $6 B$ ). Most sample sites are of moderate elevation and are located in valley bottoms where soil parent material is difficult to identify. The mapped lithologic units in the vicinity of the sites are Uinta, Green River, and Wasatch Formations. Samples in this group are rich in calcite, dolomite, the carbonate-related elements (calcium, magnesium, strontium, and total carbon) and, to a small extent, molybdenum (table 7). Patterns on the geochemical maps for total carbon and dolomite (figs. $5 P, 5 S$ ) are similar to those in figure $6 B$. The soils throughout the basin are high in carbonates due to the large amounts of carbonate minerals found in the parent materials, but lithology alone does not account for the distribution of sample loadings. In a semiarid climate, such as that found in northwestern Colorado, carbonate in soils is a function of ground and (or) surface waters as well as lithology. The geographic distribution of sample composition in this group is explained by the hydrology and ground-water composition of the basin.
The basin is dissected by a major drainage divide at a latitude of $39^{\circ} 37^{\prime}$ (the rim of the Roan Cliffs). North of this divide, ground water surfaces and discharges into streams, springs, flowing wells, or is evaporated. South of the divide, the water is discharged to springs from fractures in the Green River Formation where the formation crops out along the face of the Roan Cliffs. Predominant ions in ground waters around the margins of the basin are calcium, magnesium, and bicarbonate; whereas, ground waters in the center of the basin are predominately sodium and bicarbonate (Coffin and others, 1971). The samples with high loadings for Factor 2 are located within areas where calcium-magnesium-bicarbonate enriched ground waters are likely to come to the surface, evaporate, and precipitate as carbonates. The reason for the slight enrichment of molybdenum in samples is not known, but it may be from precipitation of insoluble calcium-molybdenum salts from alkaline weathering solutions mixing with surfacing calcium-enriched ground waters.

Samples with high loadings for Factor 3 (Group 3) are concentrated in the southeastern corner and are scattered in the northern end of the basin (fig. $6 \mathrm{C}$ ). 

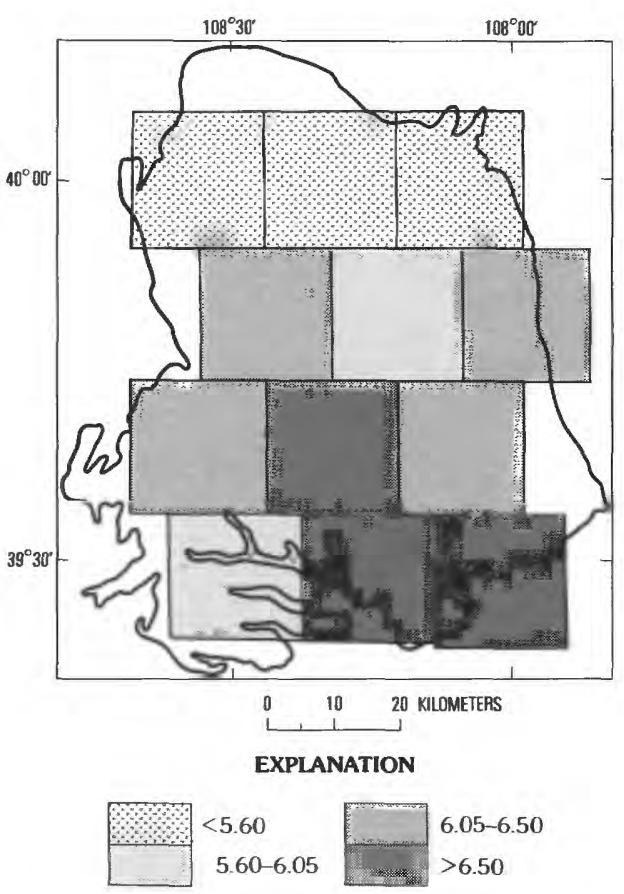

A. Aluminum in soil (in weight percent).

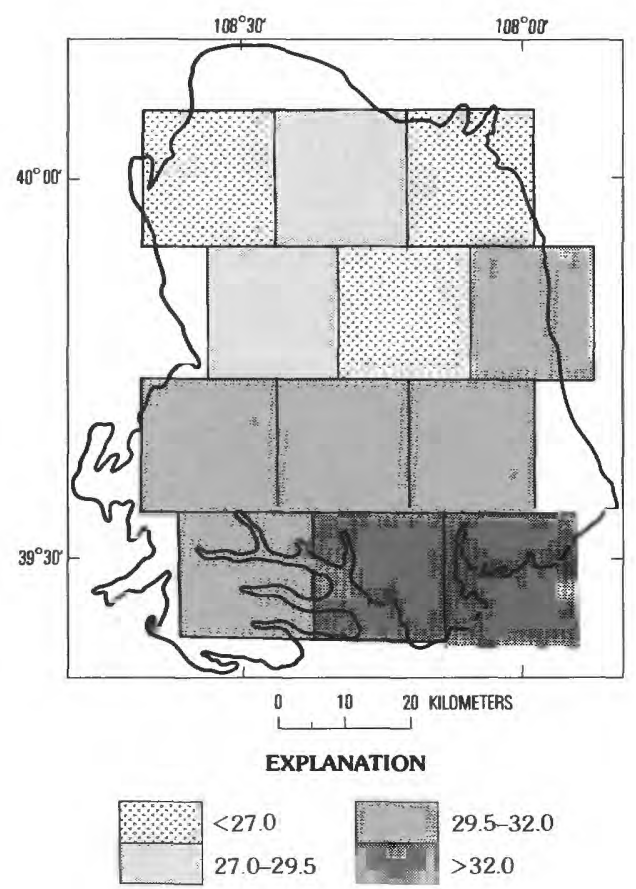

C. Copper in soil (in parts per million).

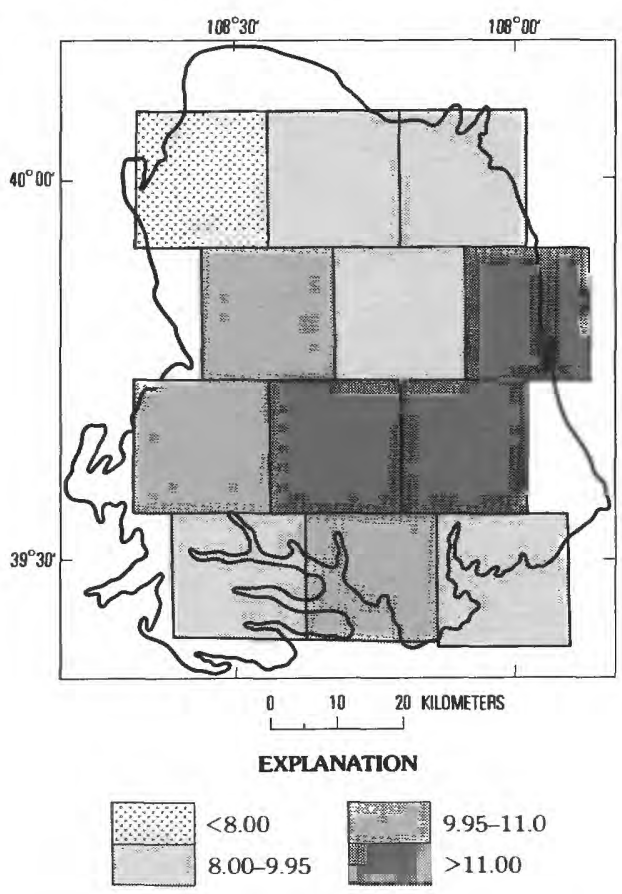

B. Cobalt in soil (in part per million).

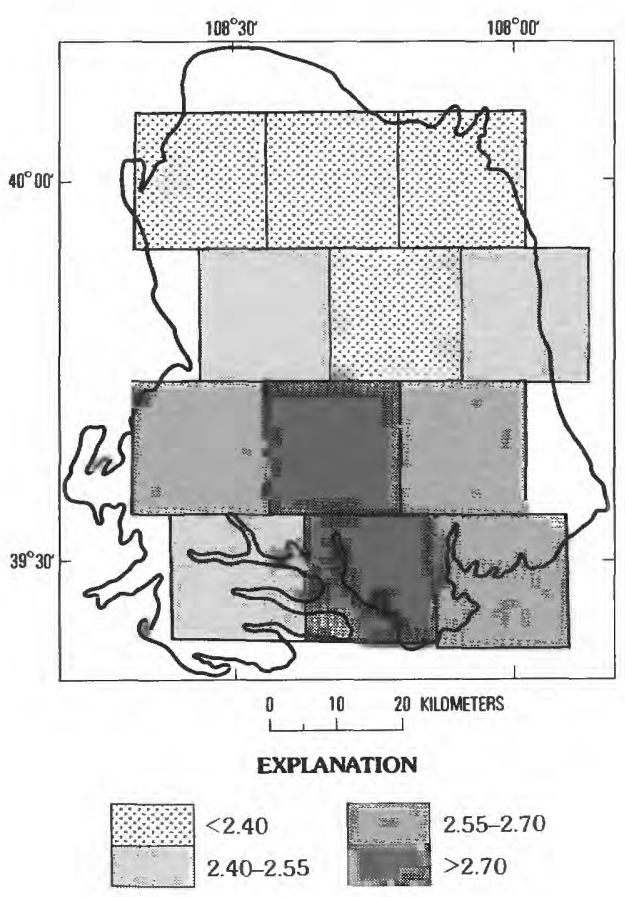

D. Iron in soil (in weight percent).

FIgURE 5.-GEOCHEMICAL MAPS FOR SOIL AND BIOGEOCHEMICAL MAPS FOR PLANT PROPERTIES THAT HAVE A VARIANCE MEAN RATIO OF 1.00 OR GREATER 

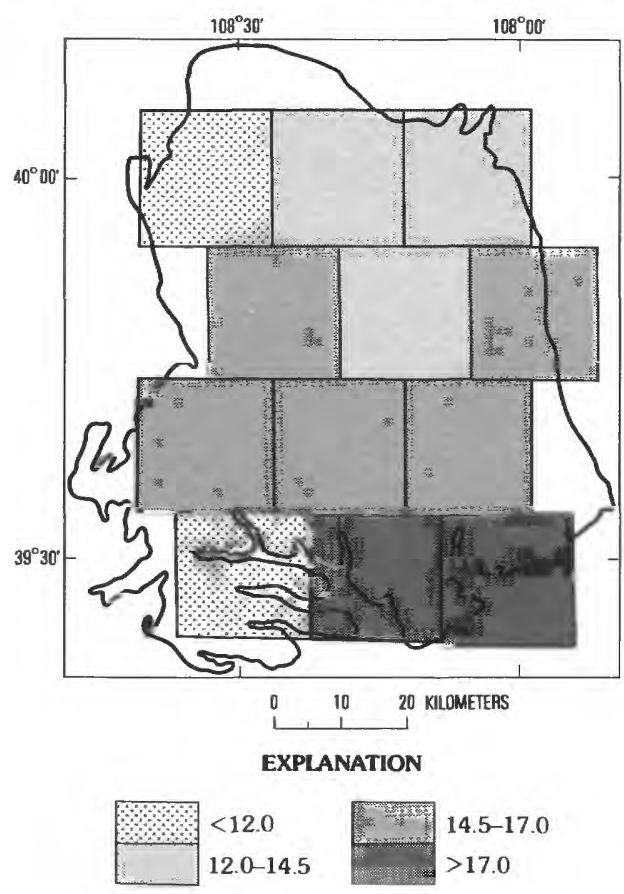

E. Lead in soil (in part per million).
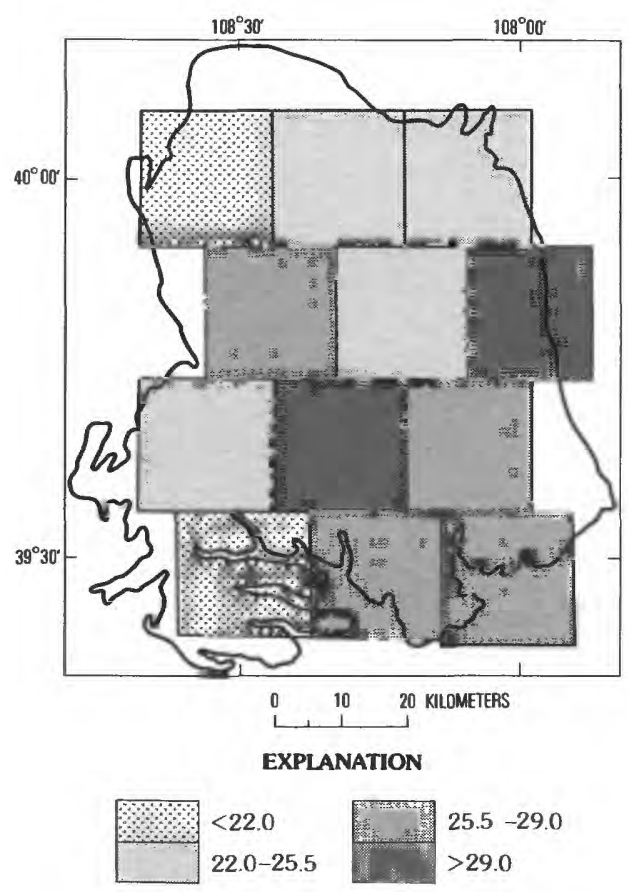

G. Nickel in soil (in parts per million).

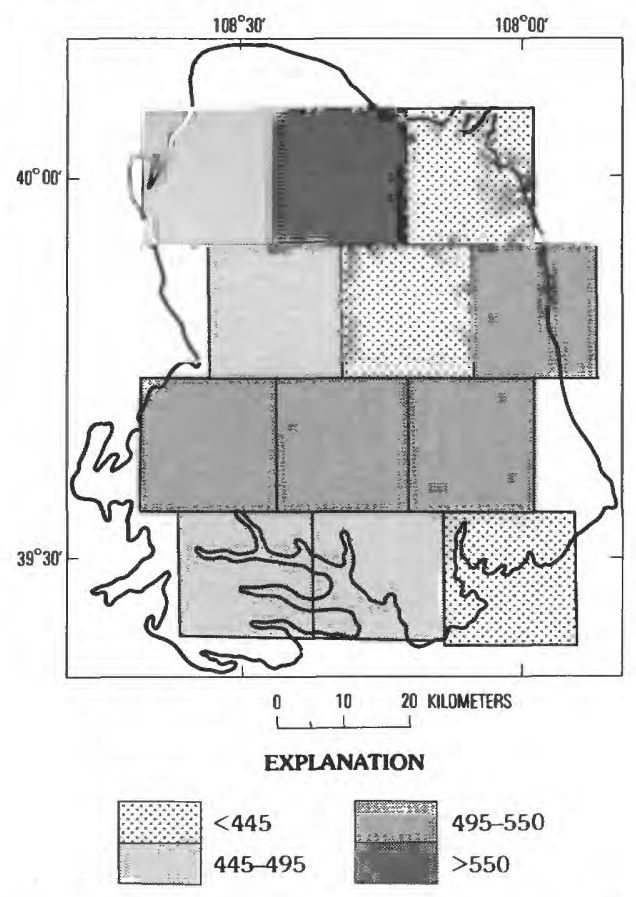

F. Manganese in soil (in parts per million).

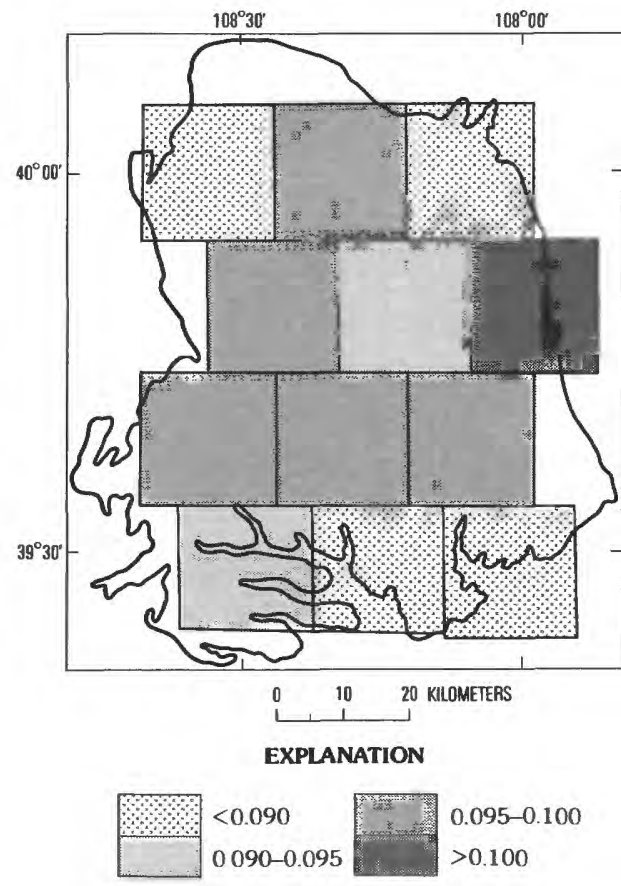

H. Phosphorus in soil (in weight percent).

FiguRE 5.-GEOCHEMICAL MAPS FOR SOIL AND BIOGEOCHEMICAL MAPS FOR PLANT PROPERTIES THAT HAVE A VARIANCE MEAN RATIO OF 1.00 OR GREATER - Continued 

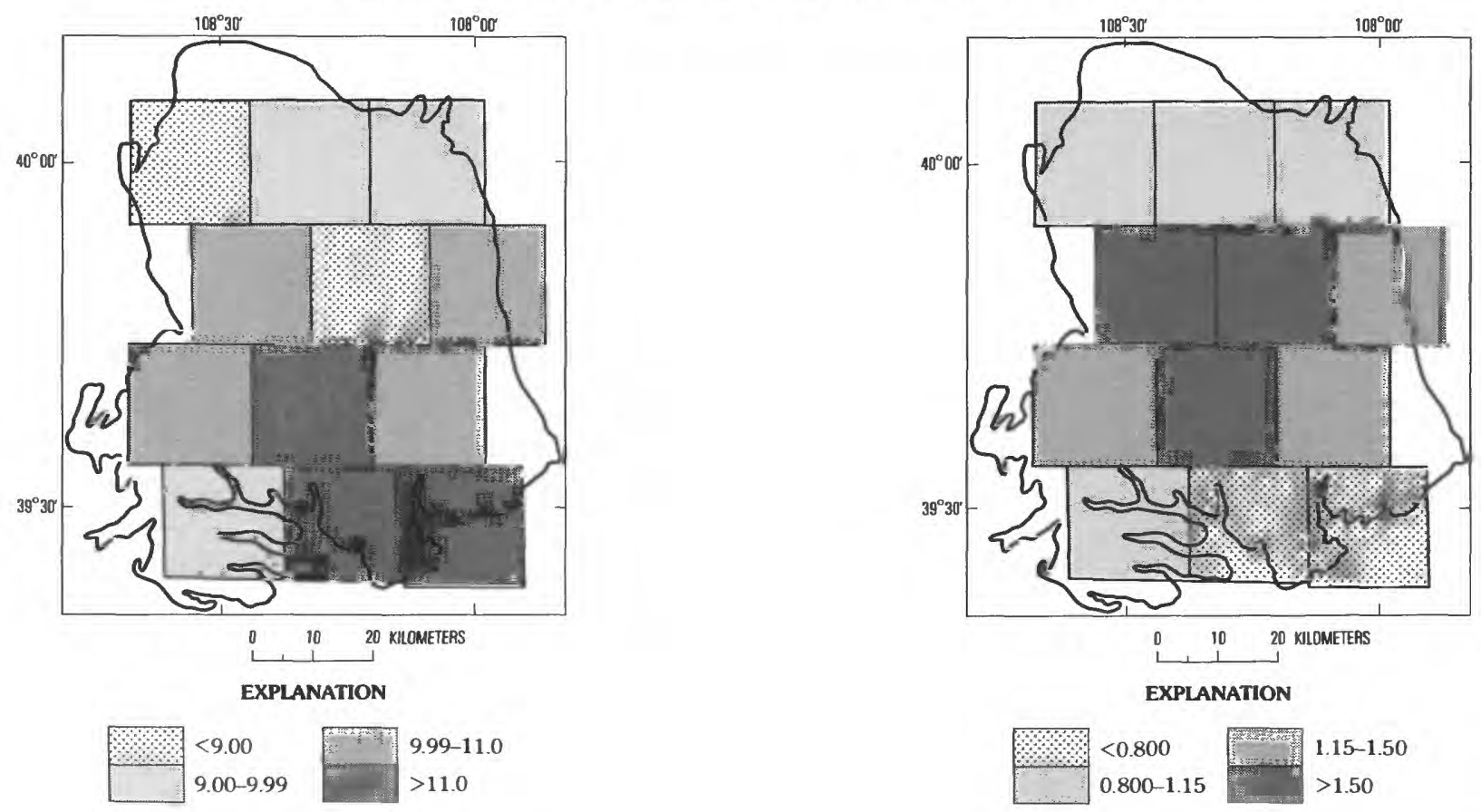

I. Scandium in soil (in parts per million).
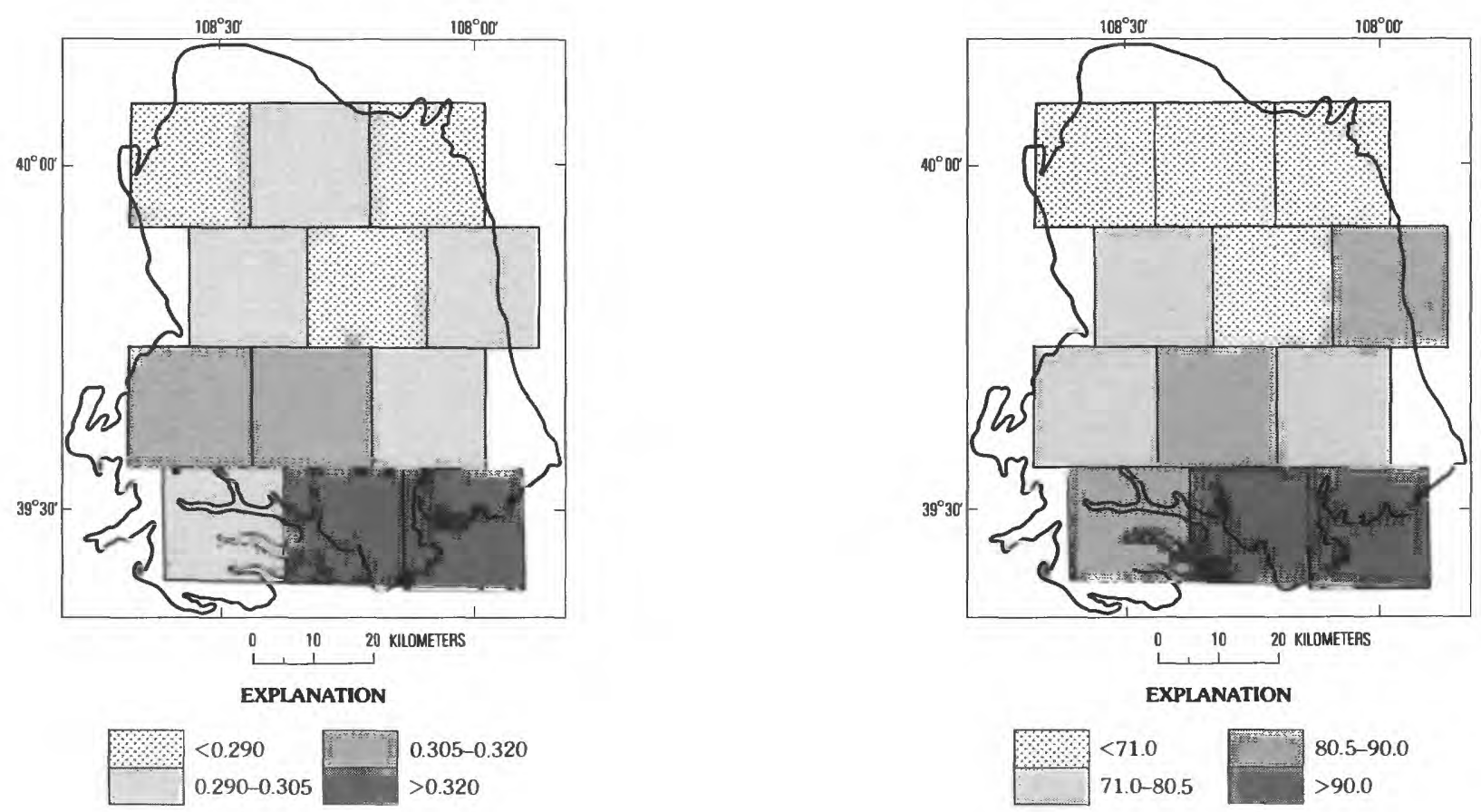

$K$ Titanium in soil (in weight percent).

L. Vanadium in soil (in parts per million).

FIGURE 5.-GEOCHEMICAL MAPS FOR SOIL AND BIOGEOCHEMICAL MAPS FOR PLANT PROPERTIES THAT HAVE A VARIANCE MEAN RATIO OF 1.00 OR GREATER — Continued 

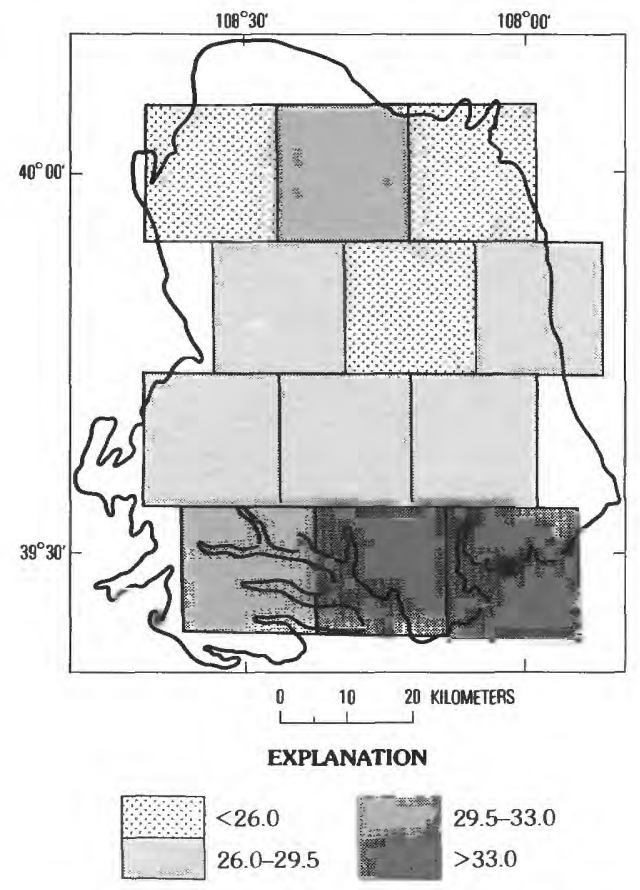

M. Yttrium in soil (in parts per million).

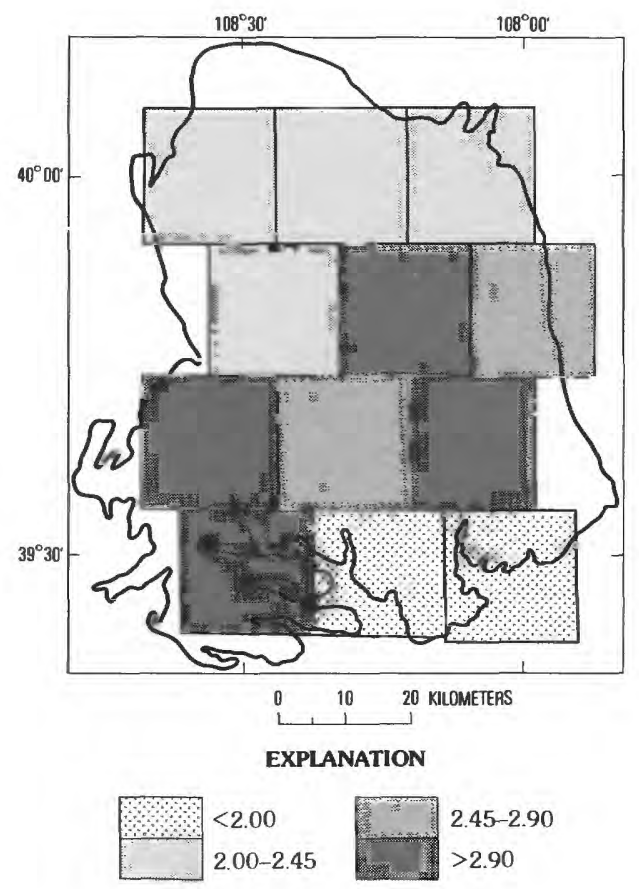

O. Organic carbon in soil (in weight percent).

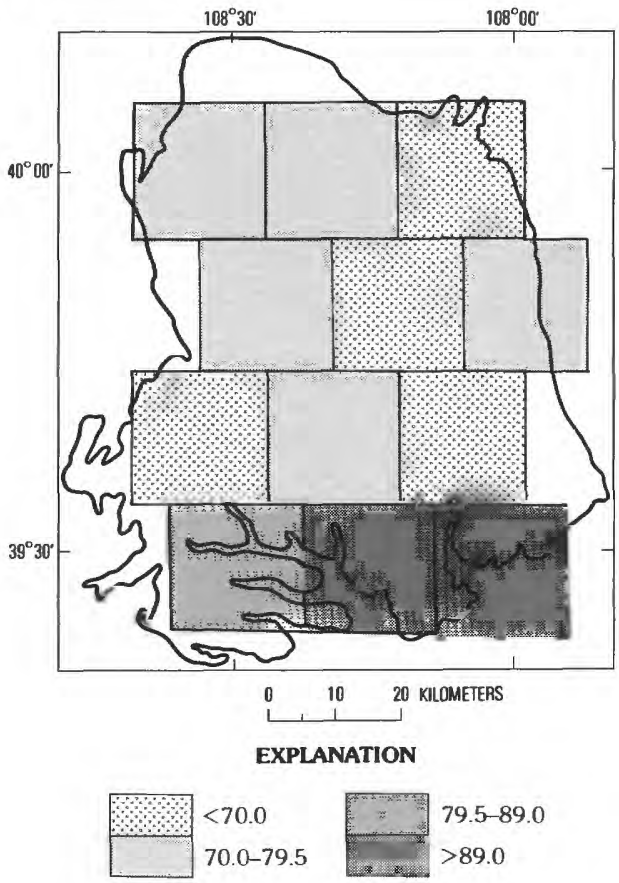

N. Zinc in soil (in parts per million).

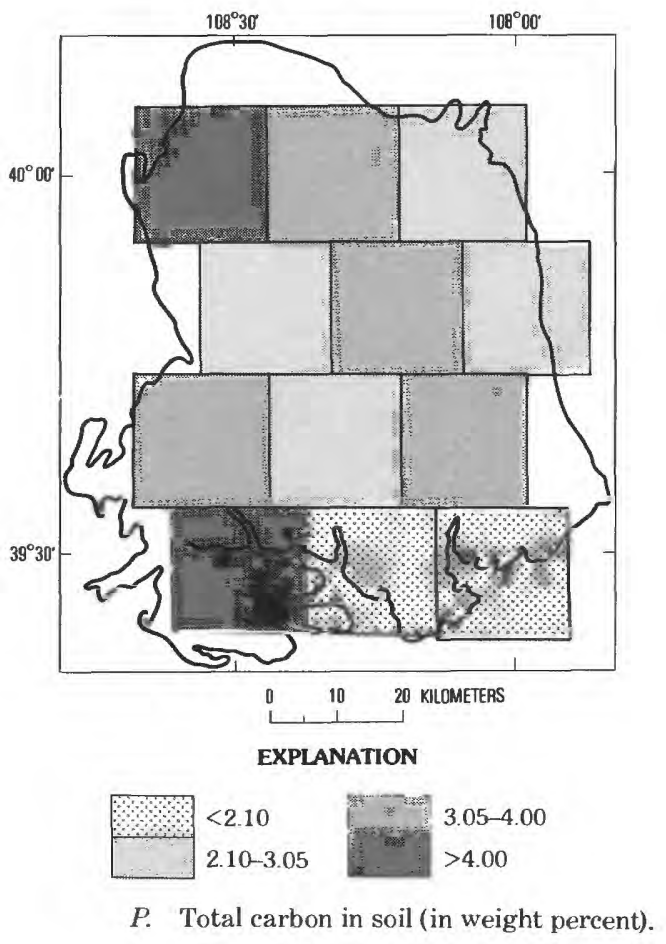

FIGURE 5.-GEOCHEMICAL MAPS FOR SOIL AND BIOGEOCHEMICAL MAPS FOR PLANT PROPERTIES THAT HAVE A VARIANCE MEAN RATIO OF 1.00 OR GREATER - Continued 

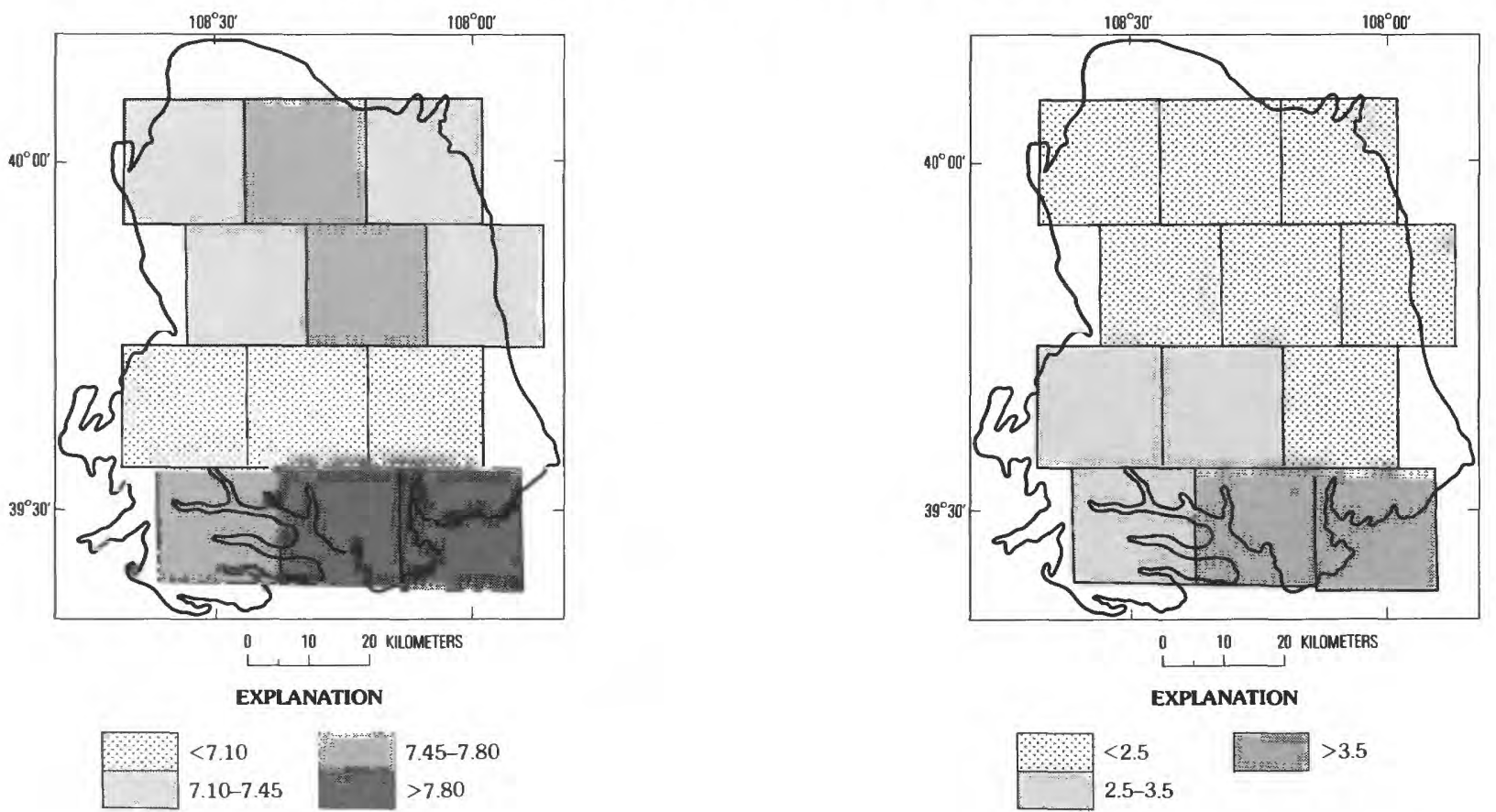

Q. $\mathrm{pH}$ in soil.

R. Clay in soil (in peak height).

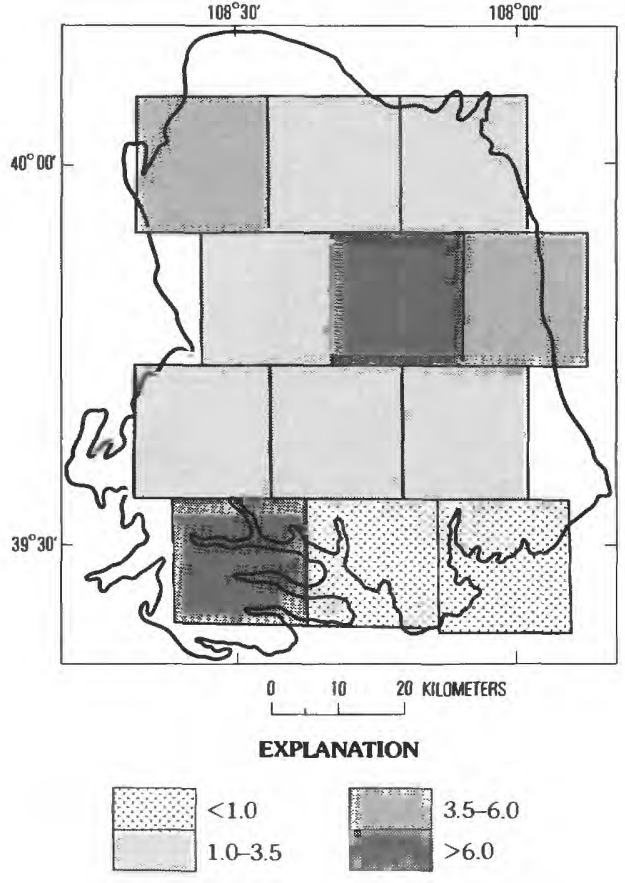

S. Dolomite in soil (in peak height).

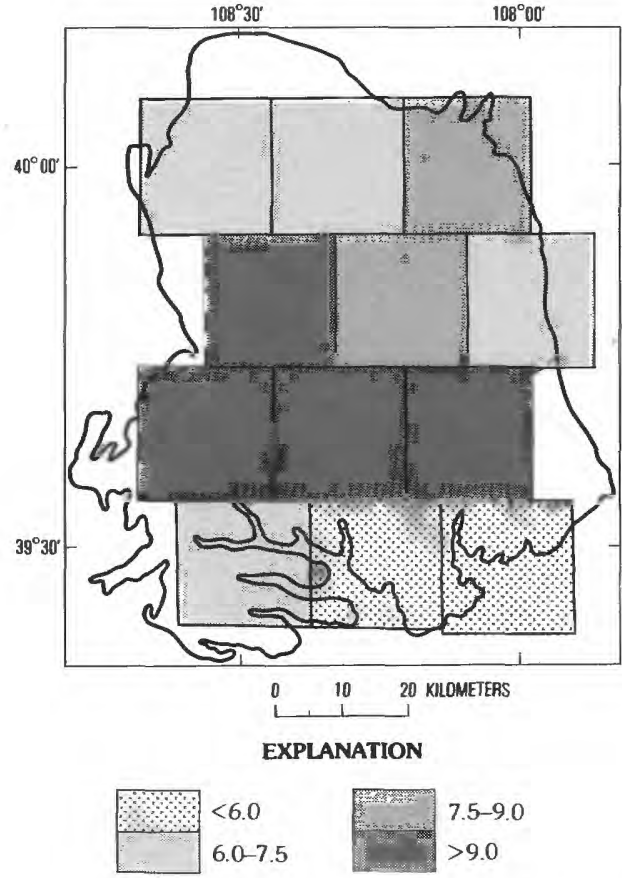

T. Sodium feldspar in soil (in peak height).

FIGURE 5.-GEOCHEMICAL MAPS FOR SOIL AND BIOGEOCHEMICAL MAPS FOR PLANT PROPERTIES THAT HAVE A VARIANCE MEAN RATIO OF 1.00 OR GREATER -Continued 


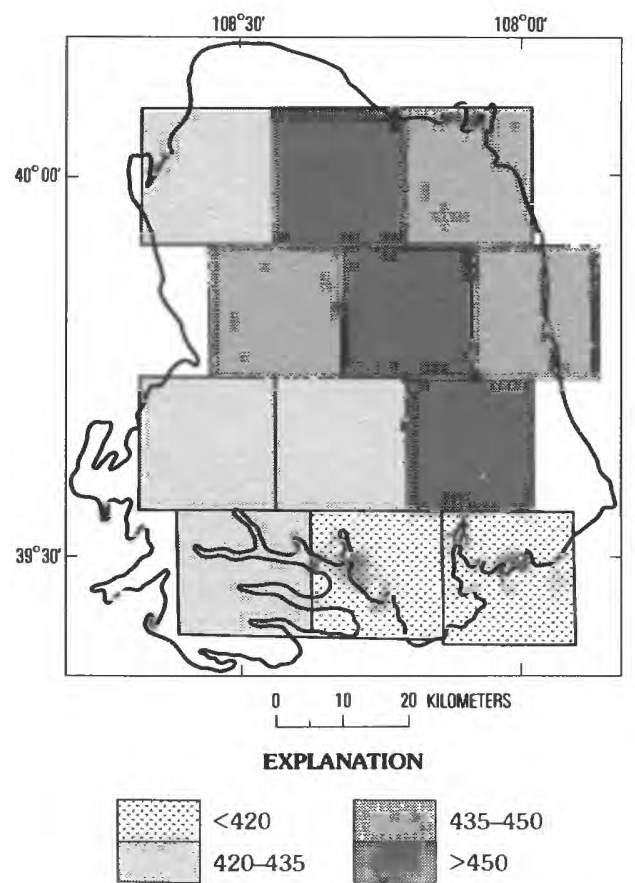

$U$. Calcium in DTPA extract (in part per million).
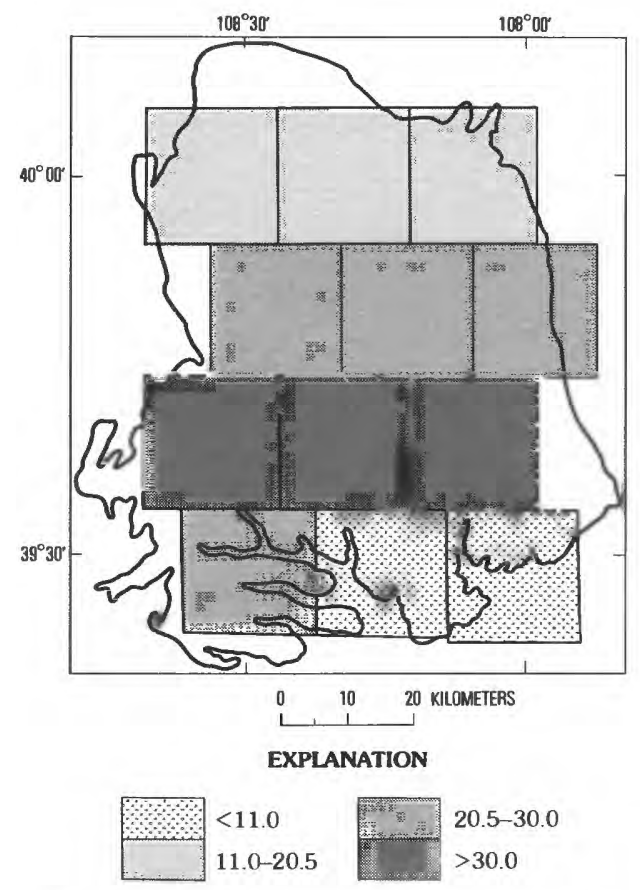

W. Iron in DTPA extract (in parts per million).

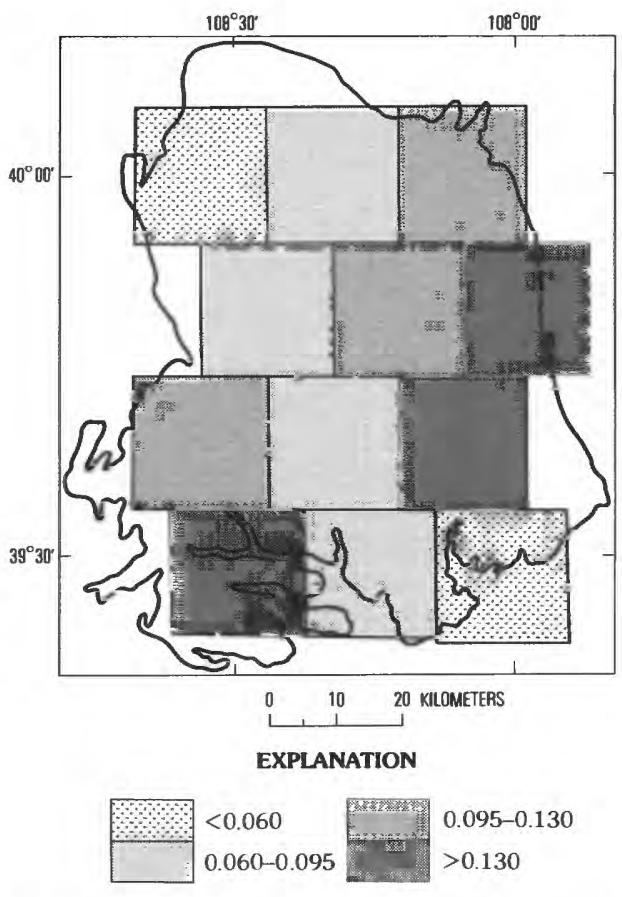

V. Cadmium in DTPA extract (in parts per million).

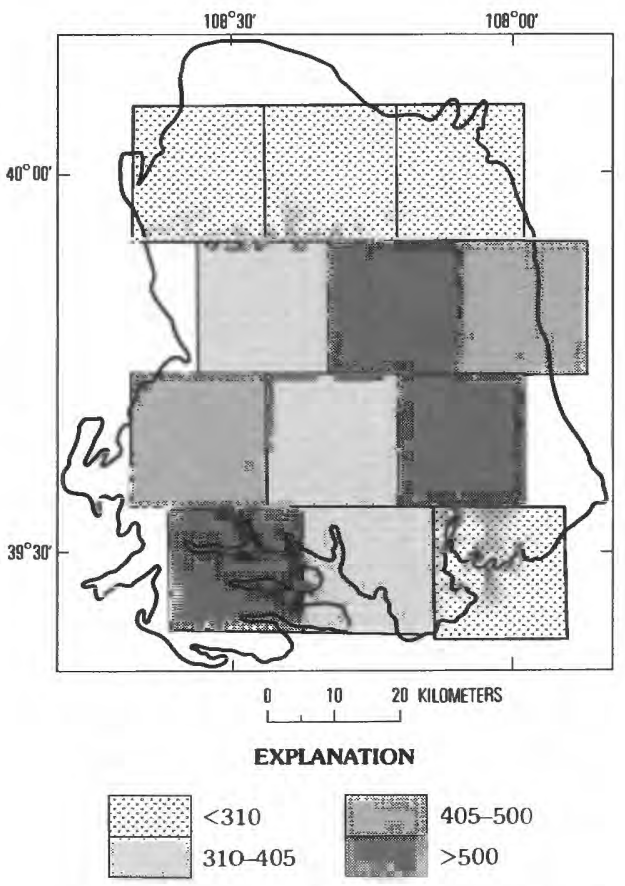

$X$. Potassium in DTPA extract (in parts per million).

FIGURE 5.-GEOCHEMICAL MAPS FOR SOIL AND BIOGEOCHEMICAL MAPS FOR PLANT PROPERTIES THAT HAVE A VARIANCE MEAN RATIO OF 1.00 OR GREATER - Continued

DTPA, extracted from soils with diethylenetriaminepentaacetic acid. 


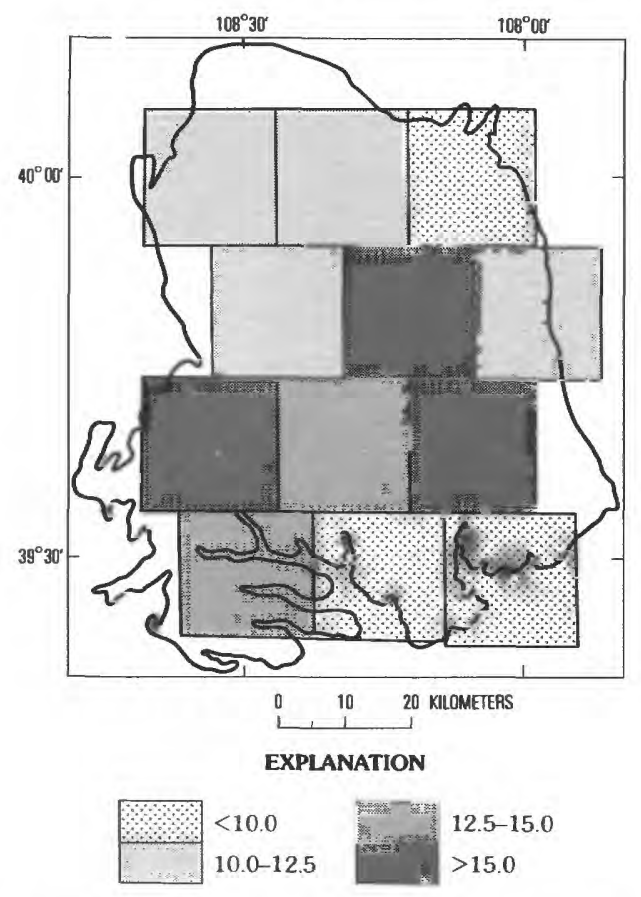

Y. Manganese in DTPA extract (in parts per million).

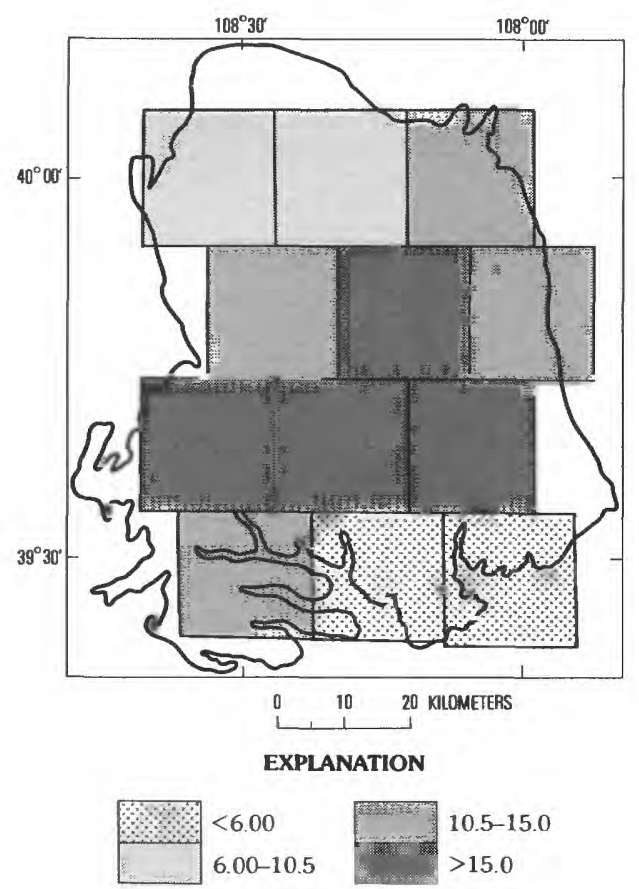

AA. Phosphorus in DTPA extract (in parts per million).

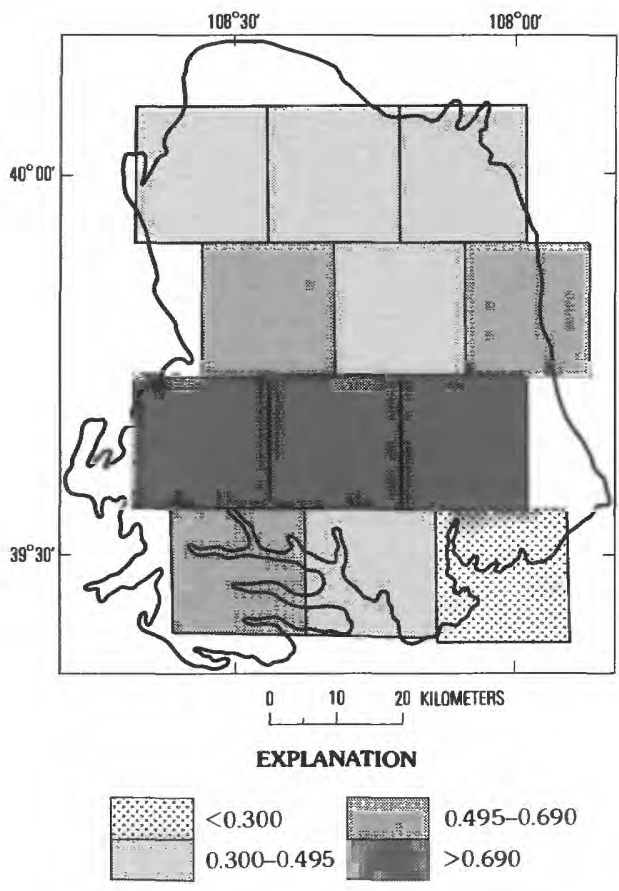

Z. Nickel in DTPA extract (in parts per million)

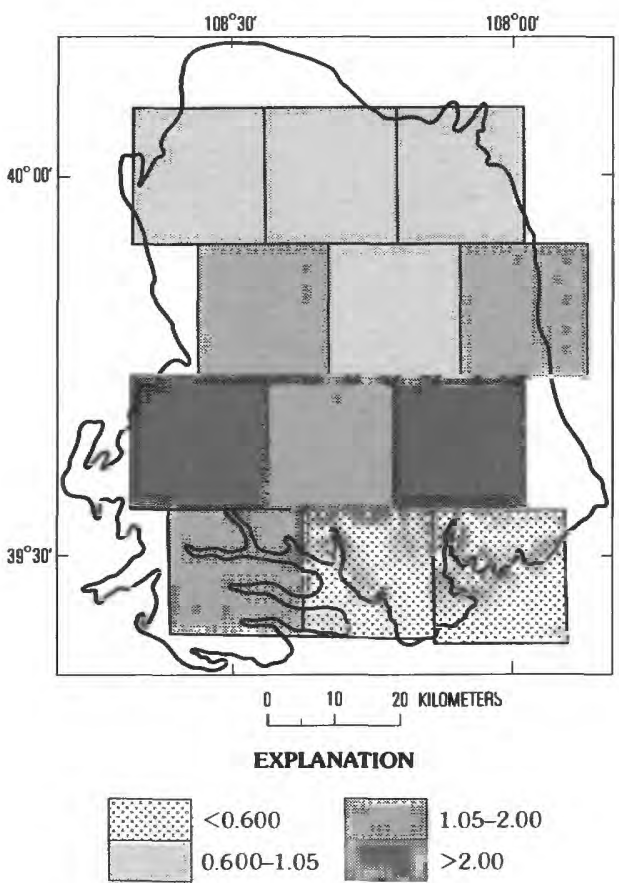

BB. Yttrium in DTPA extract (in parts per million).

FigURE 5.-GEOCHEMICAL MAPS FOR SOIL AND BIOGEOCHEMICAL MAPS FOR PLANT PROPERTIES THAT HAVE A VARIANCE MEAN RATIO OF 1.00 OR GREATER - Continued

DTPA, extracted from soils with diethylenetriaminepentaacetic acid. 


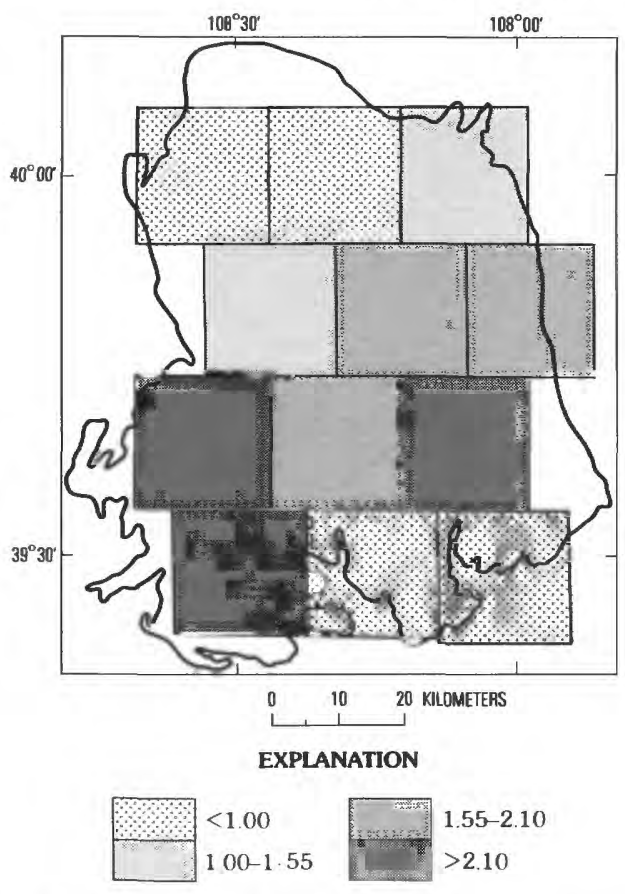

CC. Zinc in DTPA extract (in parts per million).

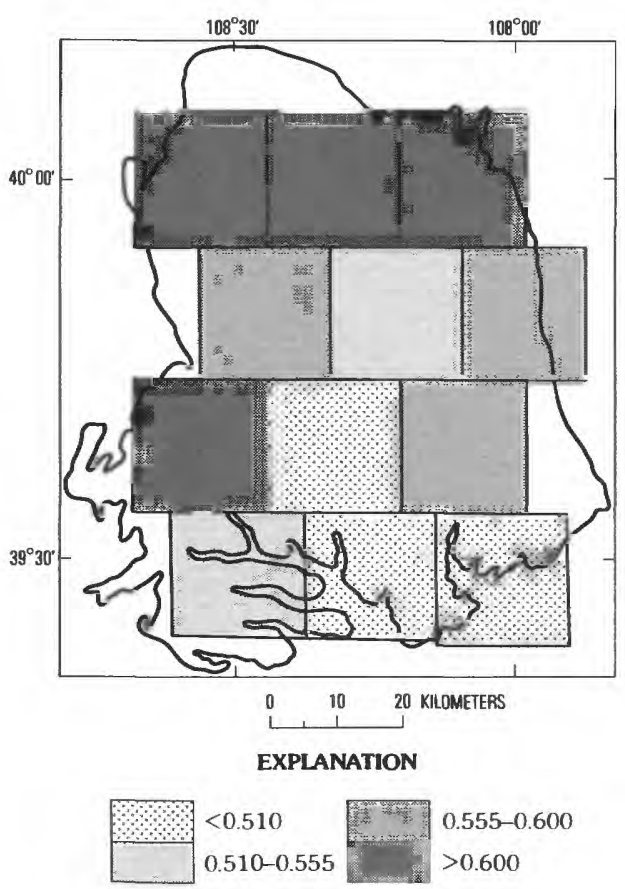

$E E$. Calcium in big sagebrush (in weight percent).

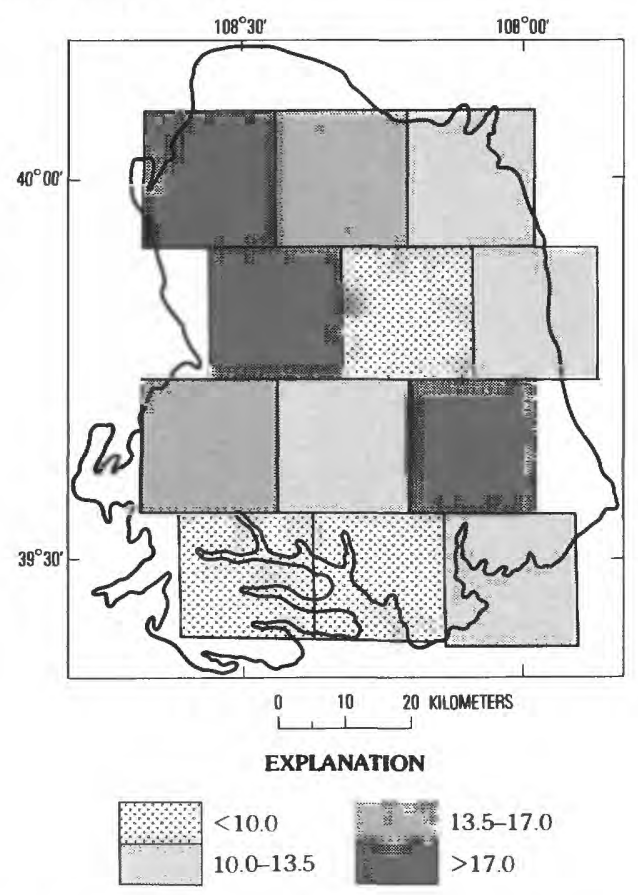

DD. Barium in big sagebrush (in parts per million).

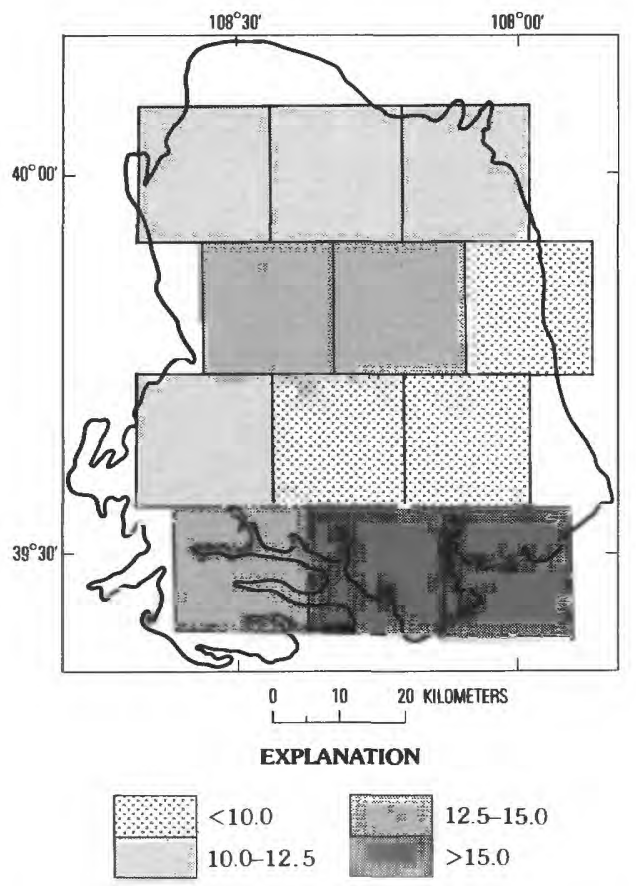

FF. Copper in big sagebrush (in parts per million).

FIGURE 5.-GEOCHEMICAL MAPS FOR SOIL AND BIOGEOCHEMICAL MAPS FOR PLANT PROPERTIES THAT HAVE A VARIANCE MEAN RATIO OF 1.00 OR GREATER —Continued

DTPA, extracted from soils with diethylenetriaminepentaacetic acid. 

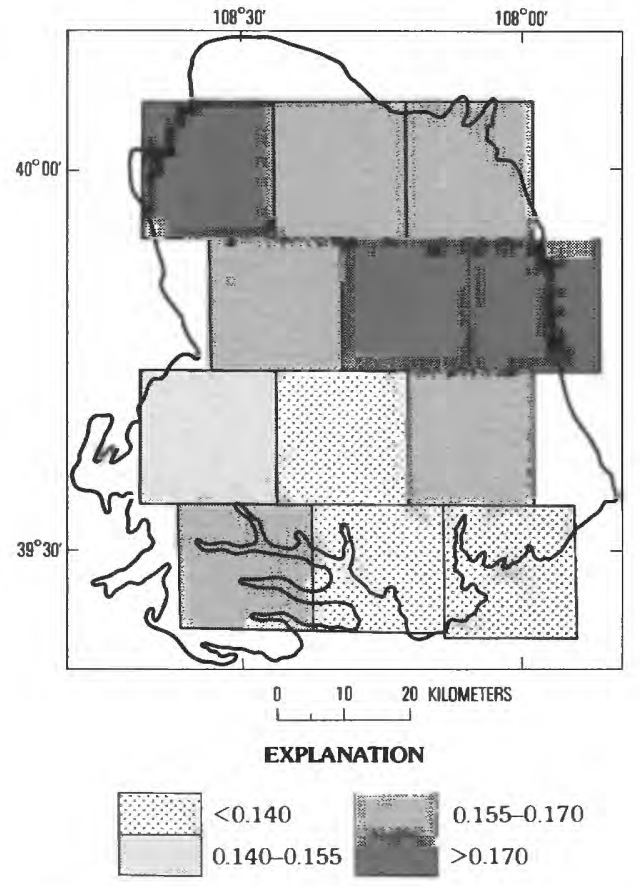

GG. Magnesium in big sagebrush (in weight percent).

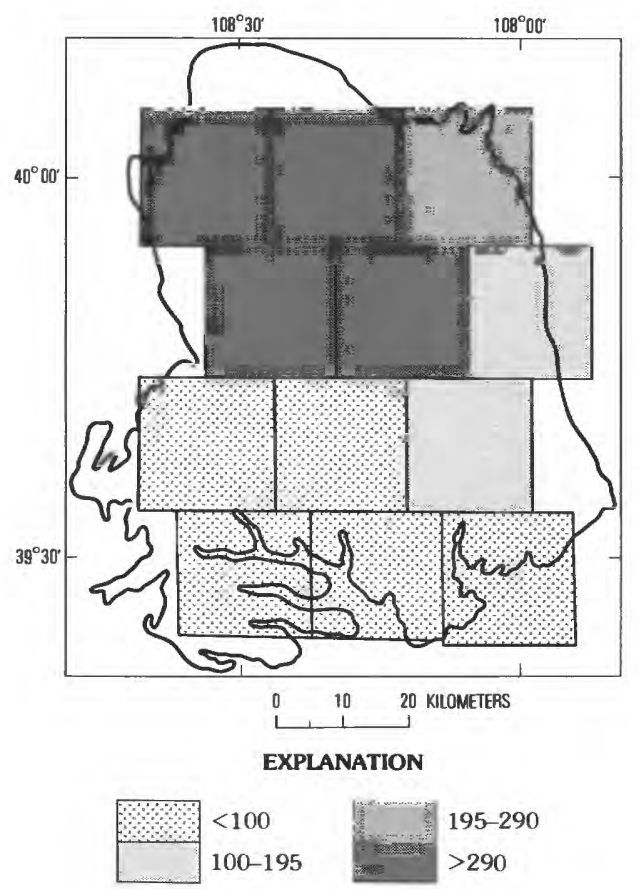

II. Sodium in big sagebrush (in parts per million).
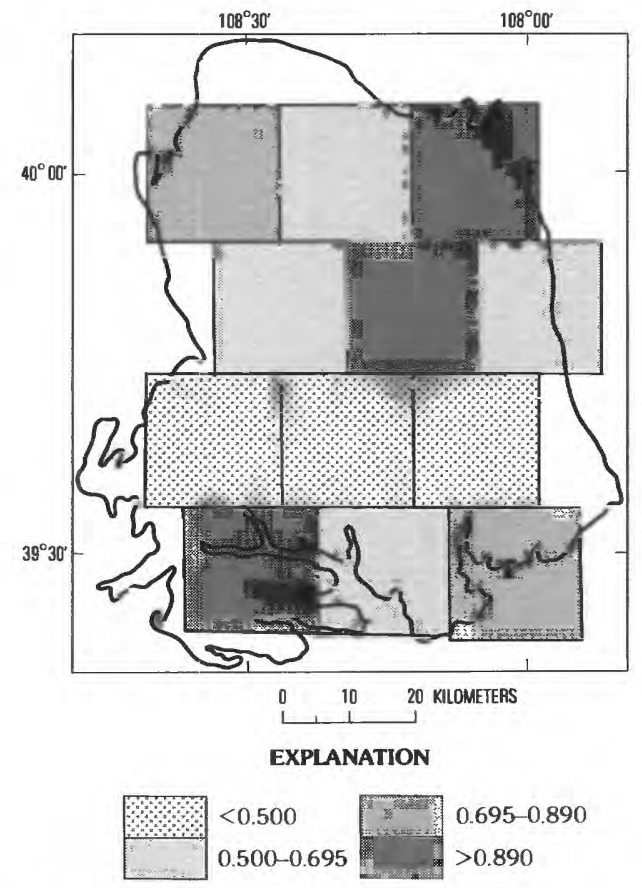

HH. Molybdenum in big sagebrush (in parts per million).

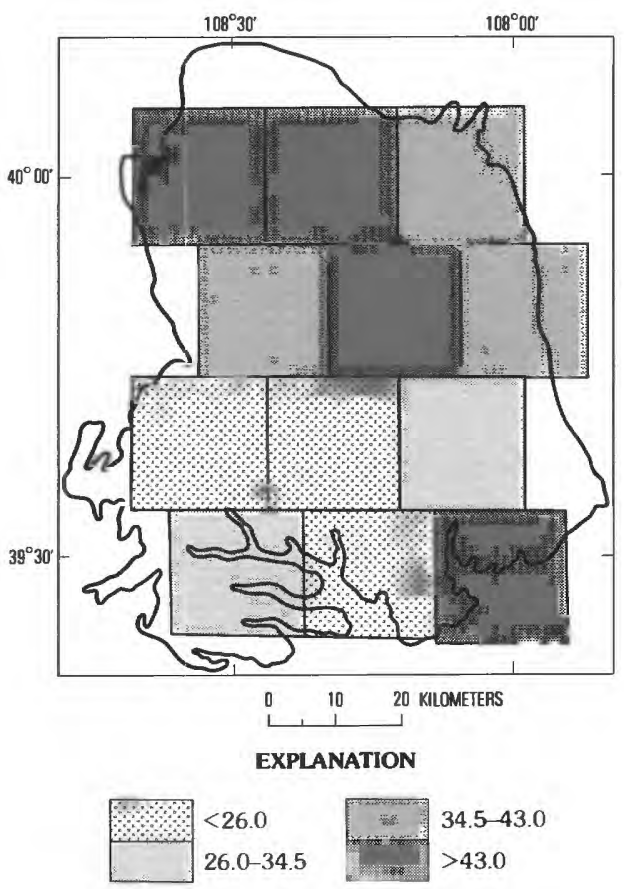

$J J$. Strontium in big sagebrush (in parts per million).

FIGURE 5. GEOCHEMICAL MAPS FOR SOIL AND BIOGEOCHEMICAL MAPS FOR PLANT PROPERTIES THAT HAVE A VARIANCE MEAN RATIO OF 1.00 OR GREATER — Continued 


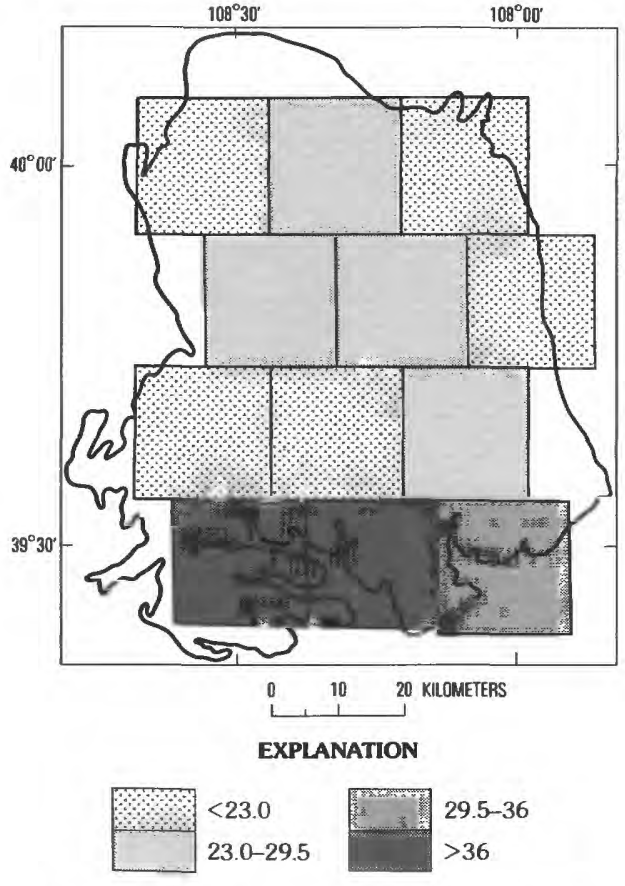

KK. Zinc in big sagebrush (in parts per million).

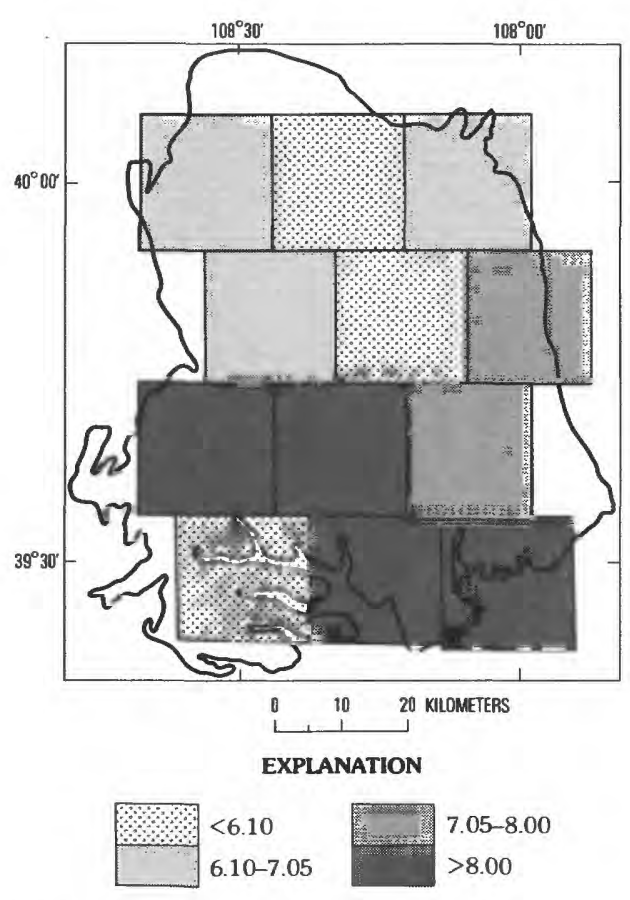

MM. Boron in western wheatgrass (in parts per million).

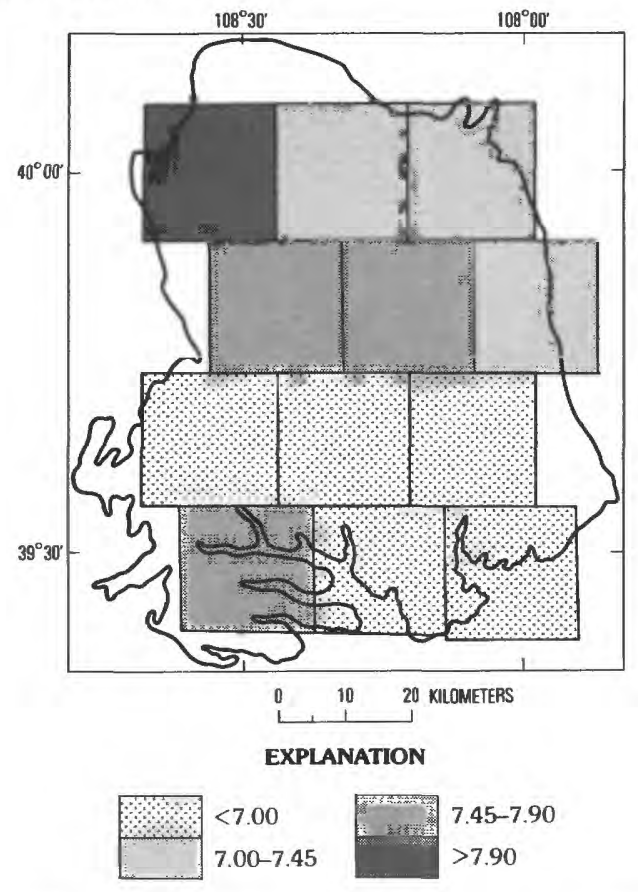

$L L$. Ash in big sagebrush (in parts per million).

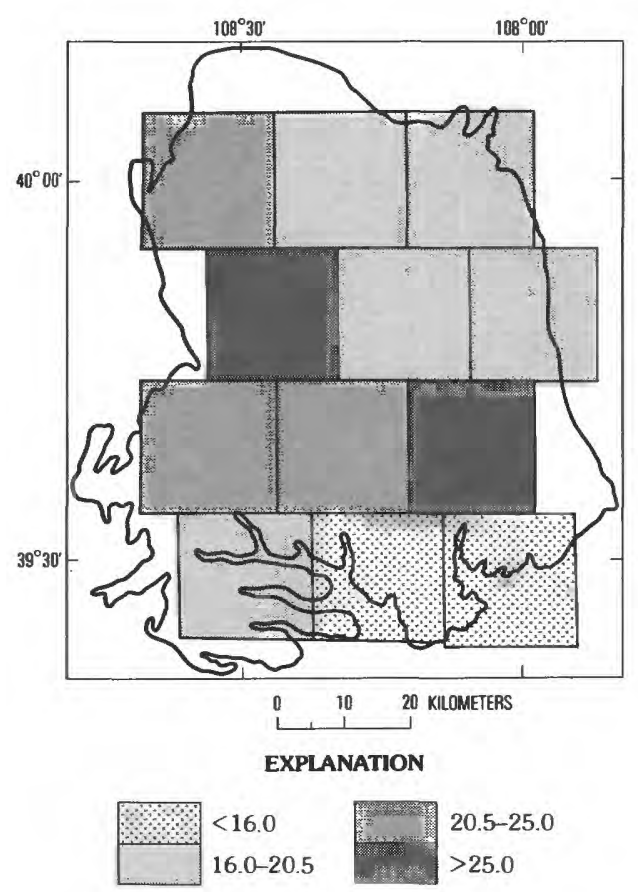

NN. Barium in western wheatgrass (in parts per million).

FIGURE 5.-GEOCHEMICAL MAPS FOR SOIL AND BIOGEOCHEMICAL MAPS FOR PLANT PROPERTIES THAT HAVE A VARIANCE MEAN RATIO OF 1.00 OR GREATER - Continued 


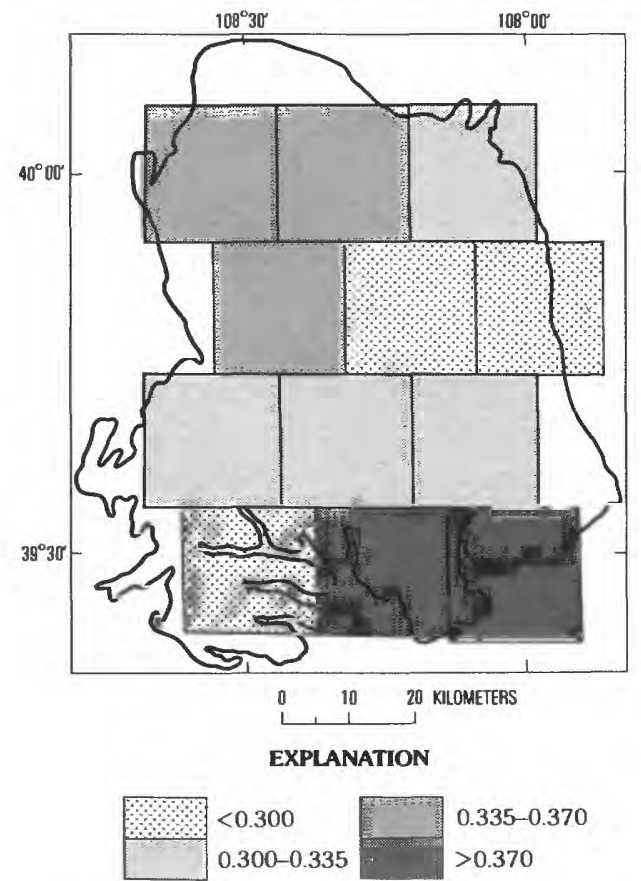

OO. Calcium in western wheatgrass (in weight percent).

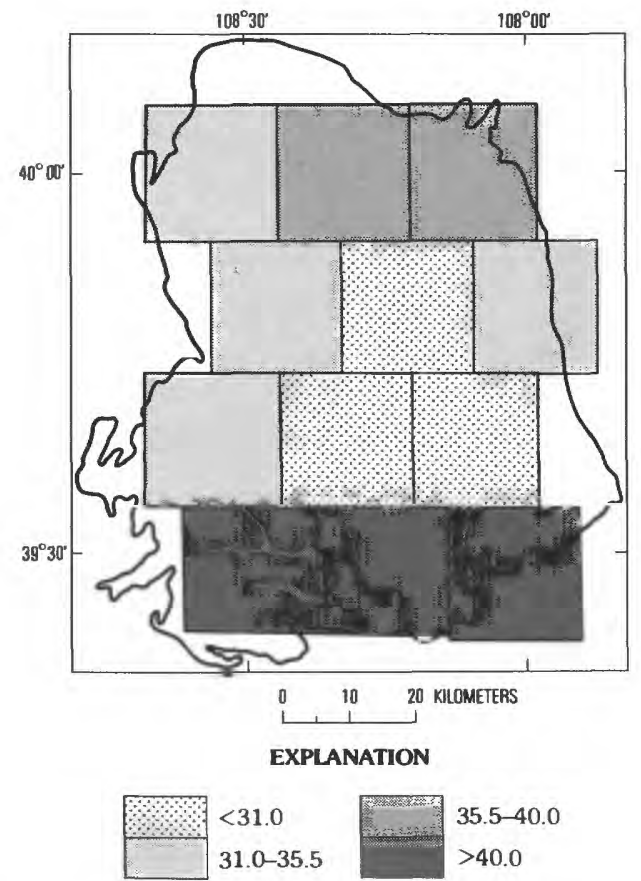

$Q Q$

Manganese in western wheatgrass (in parts per million).

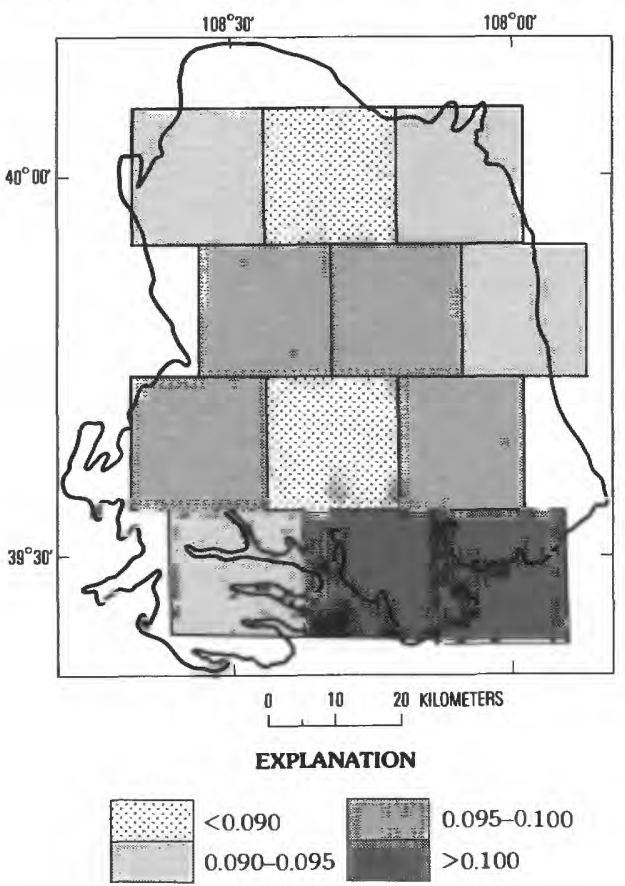

PP. Magnesium in western wheatgrass (in weight percent).

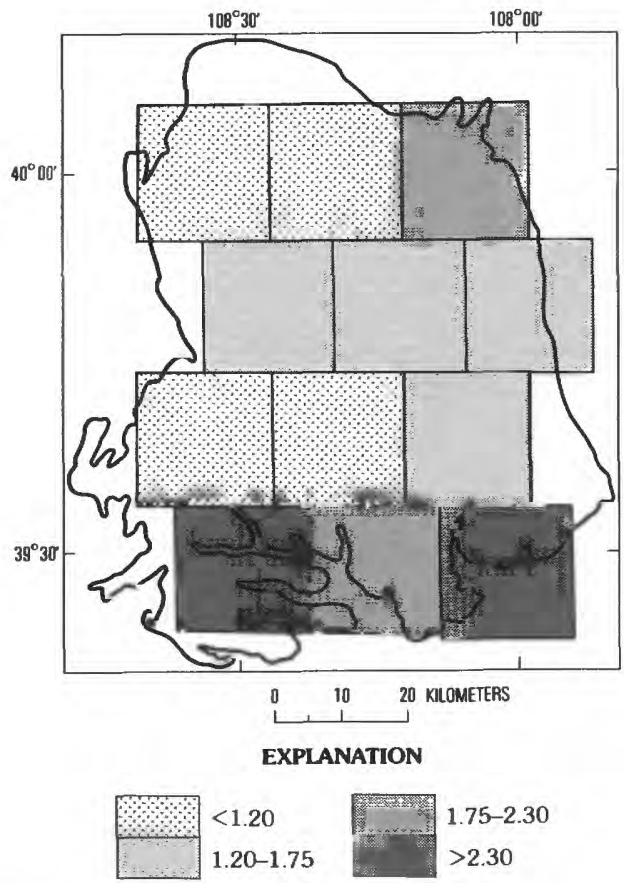

RR. Molybdenum in western wheatgrass (in parts per million).

FIGURE 5.-GEOCHEMICAL MAPS FOR SOIL AND BIOGEOCHEMICAL MAPS FOR PLANT PROPERTIES THAT HAVE A VARIANCE MEAN RATIO OF 1.00 OR GREATER - Continued 


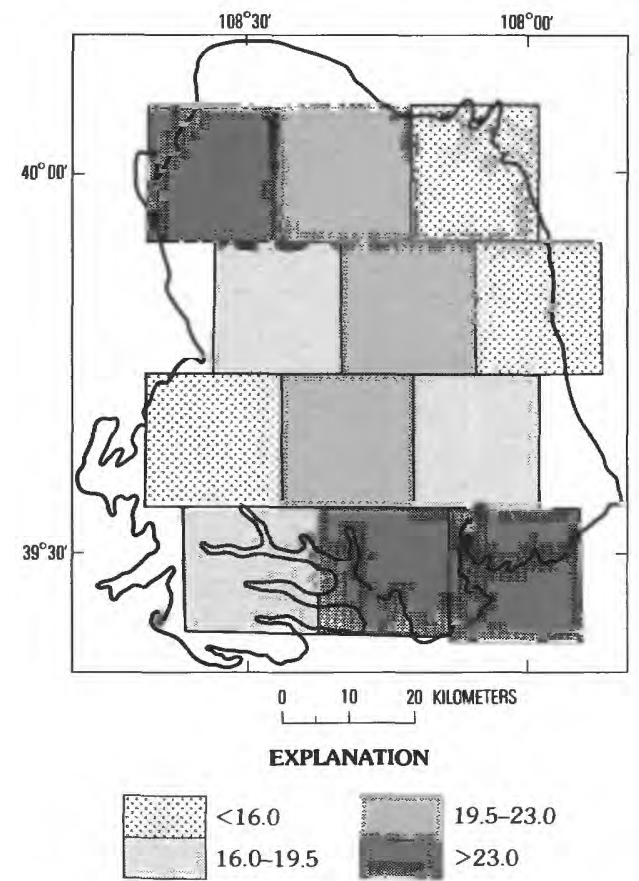

SS. Strontium in western wheatgrass (in parts per million).

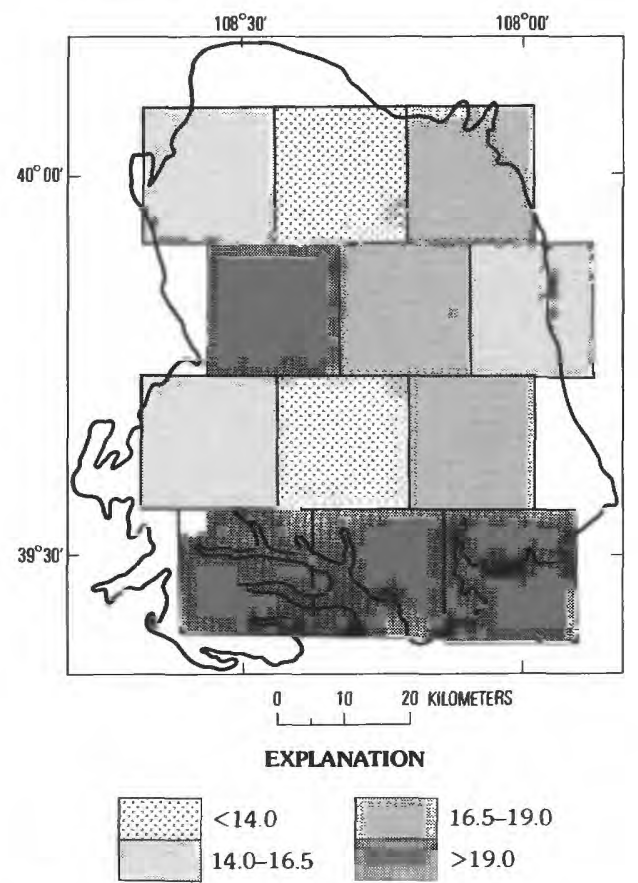

TT. Zinc in western wheatgrass (in parts per million).

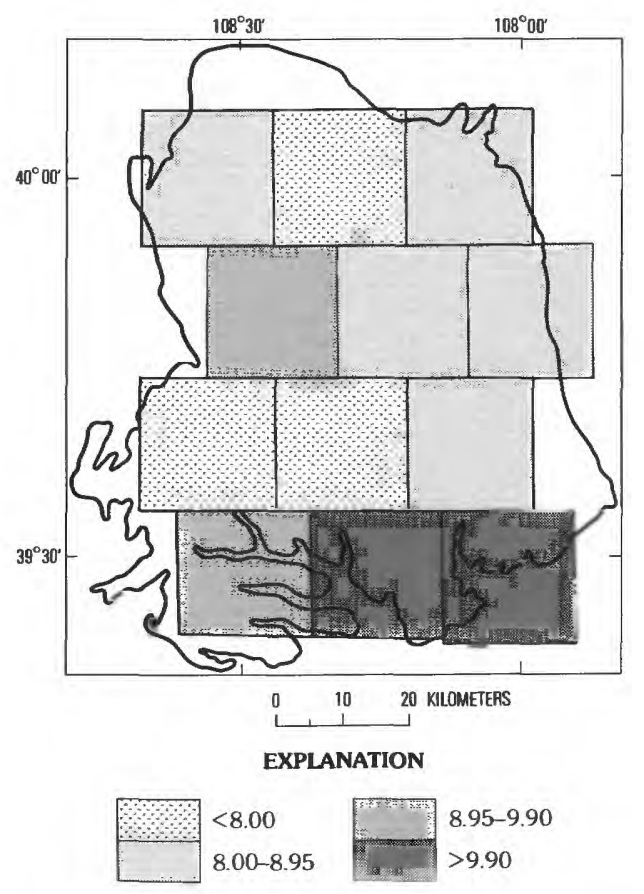

UU. Ash in western wheatgrass (in weight percent).

FIGURE 5.-GEOCHEMICAL MAPS FOR SOIL AND BIOGEOCHEMICAL MAPS FOR PLANT PROPERTIES THAT HAVE A VARIANCE MEAN RATIO OF 1.00 OR GREATER - Continued 


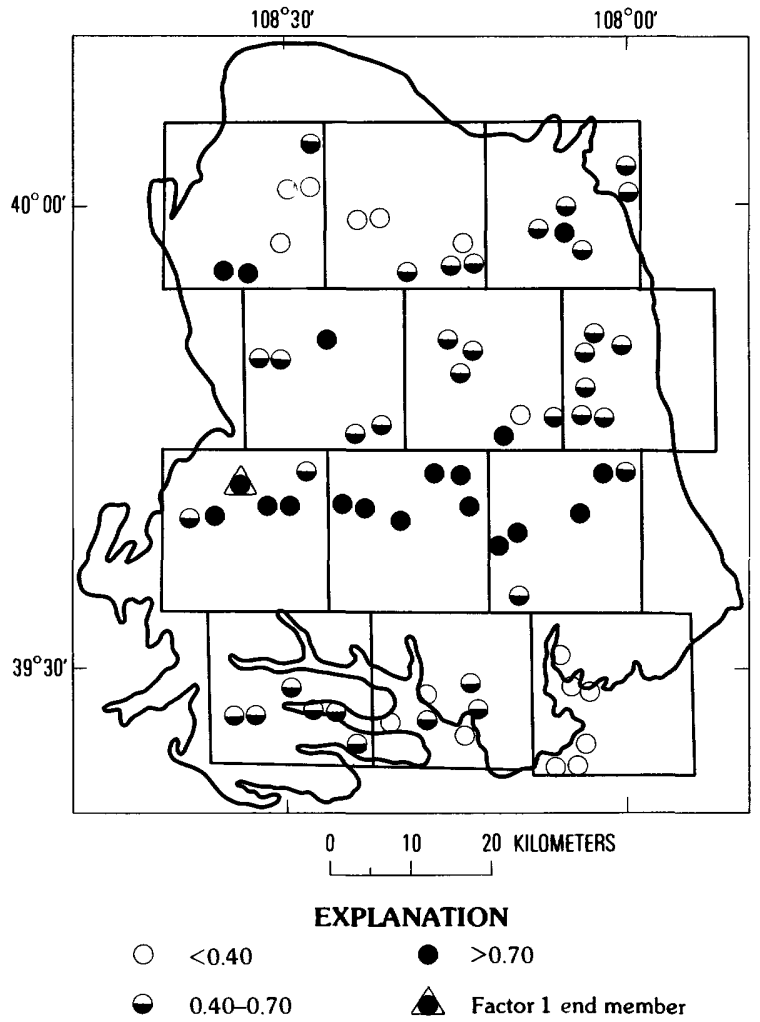

A. Factor 1 .

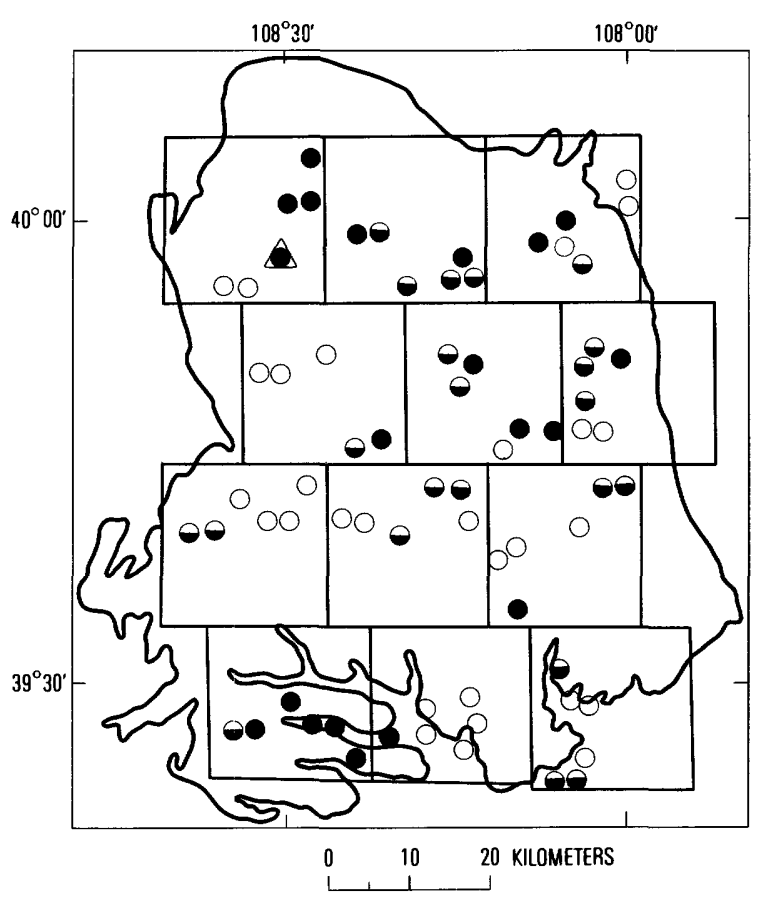

EXPLANATION

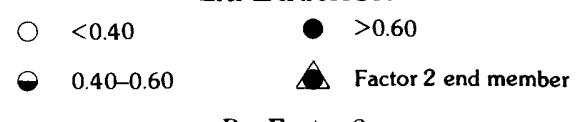

B. Factor 2 .

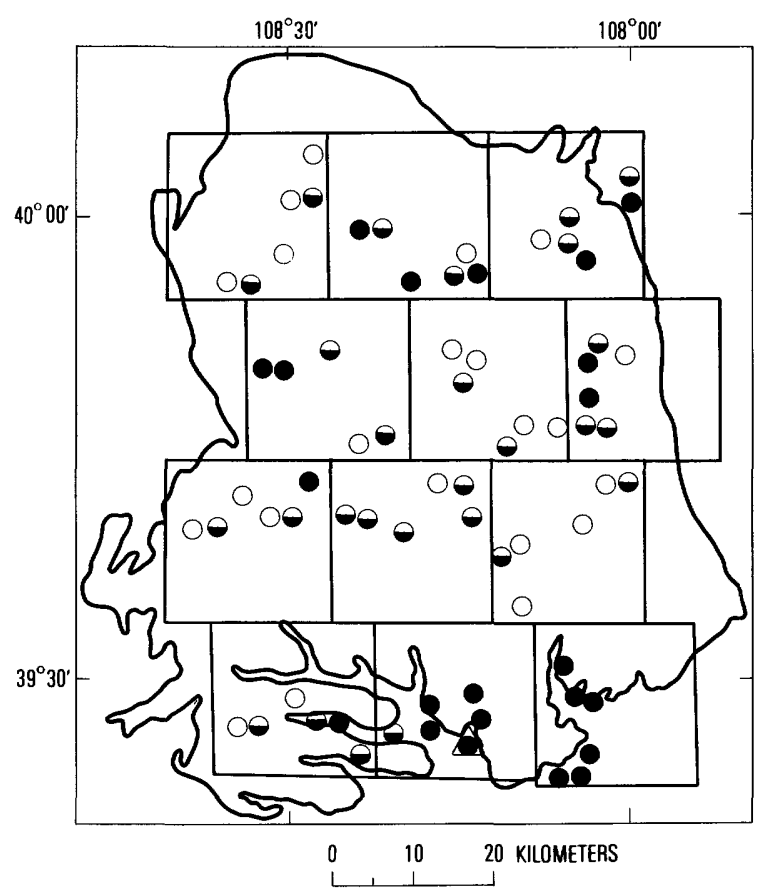

\section{EXPLANATION}

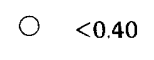

- $>0.60$

- $\quad 0.40-0.60$

A Factor 3 end member

C. Factor 3 .

FIGURE 6.-MAPS SHOWING DISTRIBUTION OF Q-MODE FACTOR LOADING FOR SOIL SAMPLES

Class intervals were determined by natural breaks in the data. 


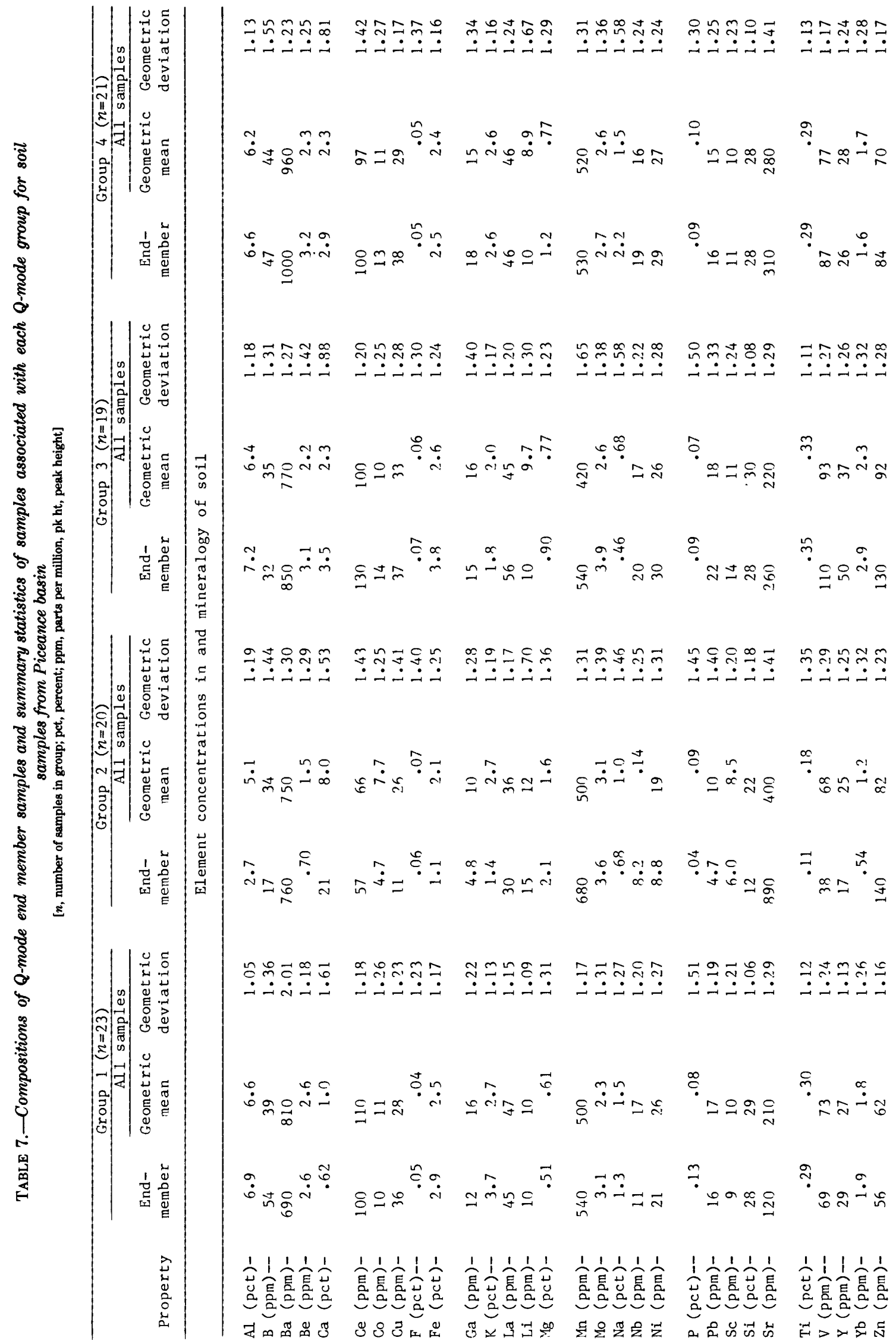




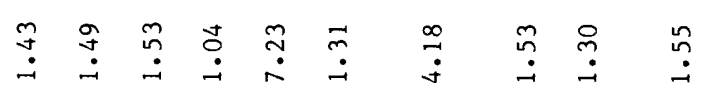

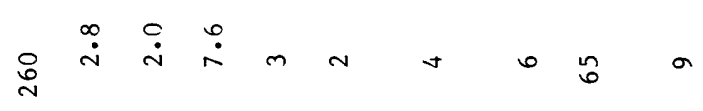

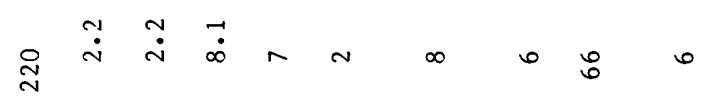

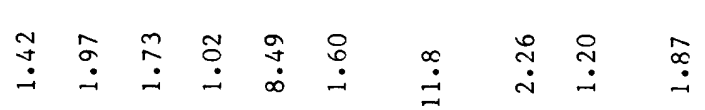

m

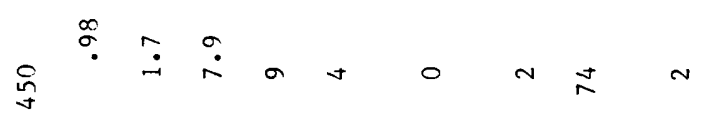

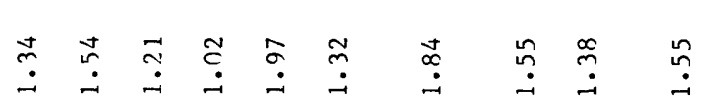

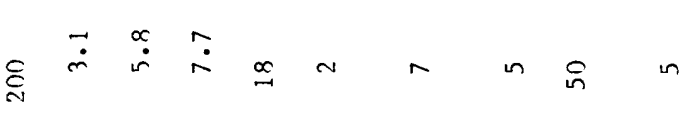

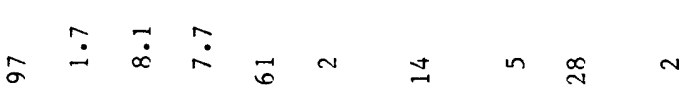

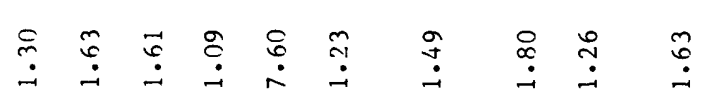

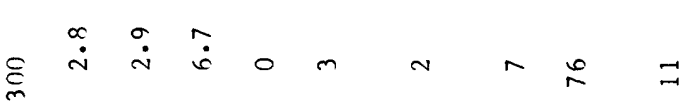

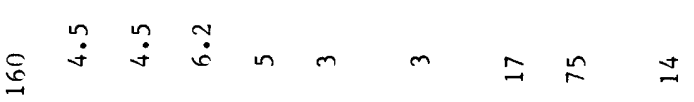

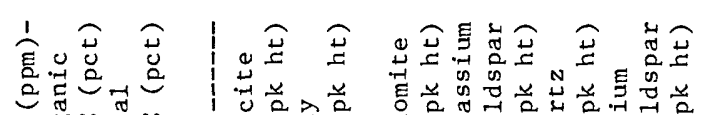

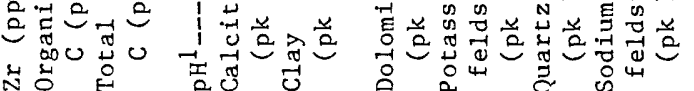

₹テ̛̃

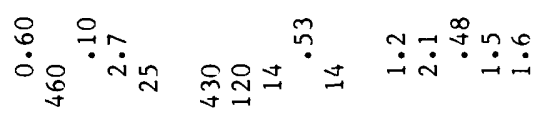

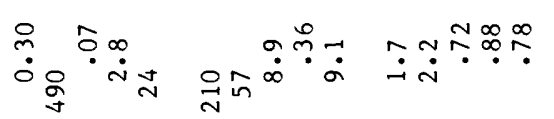

ษำํำ

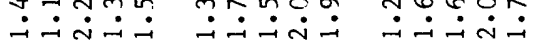

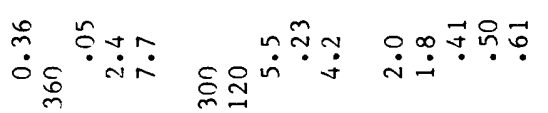

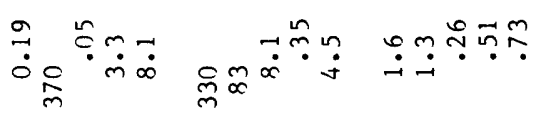

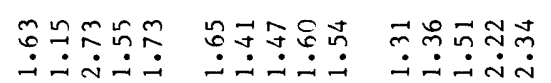

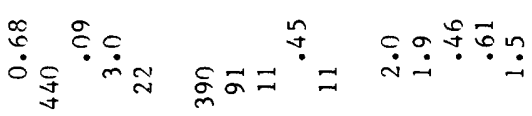

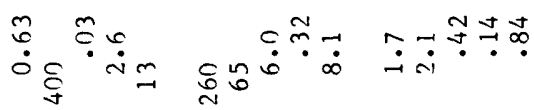

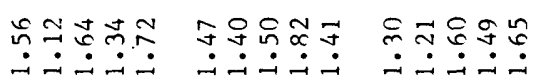

オIII

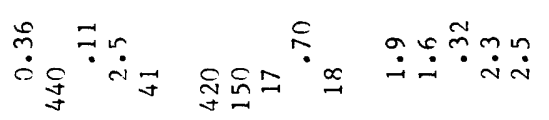

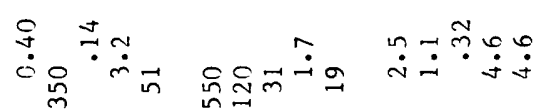

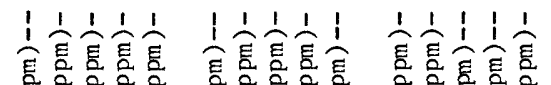

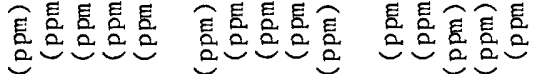

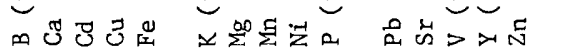


Most sample sites are in low elevation valley bottoms where the Wasatch Formation is the predominant mapped unit. Trace-element, clay, and quartz contents, along with $\mathrm{pH}$, are higher in these samples (table 7). The quartz and clay influence on this factor is due to the high content of these minerals in the Wasatch Formation, 45-50 percent and 25-30 percent, respectively. The high soil $\mathrm{pH}$ can be attributed to low humus contents due to the increased aridity at lower elevations. Elements commonly associated with resistate minerals (silicon, titanium, and zirconium) are rich along with quartz. The high concentrations of trace elements (copper, lanthanum, nickel, lead, scandium, vanadium, ytterbium, yttrium, and zinc) could be due to high concentrations in parent material or adsorption onto clays of trace ions from weathering solutions. The high concentrations due to adsorption could be controlled by an increase of clay content in the soil and (or) an increase in the cation exchange capacity of the clay due to higher $\mathrm{pH}$. Geochemical maps of these elements, $\mathrm{pH}$, and clay (fig. 5) substantiate the increase in values in the southeast corner of the basin.

Samples in Group 4 are of intermediate composition, being neither rich nor poor in elemental or mineralogical properties (table 7). This group can be considered as a geochemical composite of the other three groups.

Dean, Ringrose, and Klusman (1979) also computed a $Q$-mode factor analysis of the elemental composition of Piceance basin soils. Their study used a four-factor model. Factor 1 samples were concentrated in the southern part of the basin, and their higher trace-metal concentrations were attributed to Green River parent material. Factor 2 samples were concentrated in the northern and southern parts of the basin, and their higher concentrations of carbonate-related elements were contributed to ground water hydrology in the northern part and Green River parent material in the southern part of the basin. Factor 3 samples were scattered throughout the basin, and their higher silica concentrations were attributed to Uinta and Wasatch parent materials. Factor 4 samples were concentrated in the northern end of the basin, and their higher concentrations of sodium and strontium were attributed to ground water hydrology. Overall, the results of our $Q$ mode model are similar to those in the study by Dean, Ringrose, and Klusman; however, there are two differences regarding the interpretation of the factors. Dean, Ringrose, and Klusman attributed the high trace-element concentrations in soils in the southern part of the basin (their Factor 1) to the Green River Formation; whereas, we attribute the anomaly to mineralogy of the
Wasatch Formation and soil pH (our Factor 3). Dean, Ringrose, and Klusman suggested that the minerals in the Green River Formation are controlling the high concentrations of carbonate-related elements in the southern part of the basin (their Factor 2); whereas, we attribute these higher concentrations to surfacing ground waters (our Factor 2).

$Q$-mode factor modeling was performed on the plant data in order to help define processes controlling the geographic trends on the biogeochemical maps in figure 5. The results of this modeling are highly speculative at this time and await further study.

\section{RECLAMATION POTENTIAL OF BASIN SOILS}

The soil geochemical and plant biogeochemical maps in figure 5 indicate that some areas within the basin are naturally high or low in certain soil and (or) plant properties. These natural differences could be useful in considering areas for locating spoil piles and for collecting reclamation topsoil. The potential for trace-element toxicity in revegetation plant materials has been recognized by Dean, Ringrose, and Klusman (1979), Kilkelly and Lindsay (1979), and Schwab, Lindsay, and Marx (1980). Location of spoil piles in and collection of reclamation topsoil from areas identified from the maps in figure 5 as being naturally low in soil trace elements might be appropriate in order to decrease the possibility of trace-element toxicity in revegetation materials. Q-mode results for soils further delineate these lowtrace-element areas with respect to the area's other geochemical characteristics. The biogeochemical maps for big sagebrush and western wheatgrass provide information useful in accessing availability of the trace elements to plants within the area.

The soils along the rim of the Roan Cliffs are generally low in concentrations of trace elements. The soils are developed from Uinta or Green River Formation parent material; the soils receive the most precipitation and have the coolest temperatures within the basin. If soils from this area were collected and transported to reclamation sites in the northern part or southeastern corner of the basin, increases in concentrations of certain trace elements may occur from surfacing ground water, weathering solutions, and (or) an increase in $\mathrm{pH}$. We speculate, therefore, that the rim of the Roan Cliffs would be the best location for reclamation with regards to trace elements in soils.

Plants grown along the rim have low concentrations of many of the potentially toxic trace elements that are higher in plants in the southeast corner of the basin. 
There is a slight increase in concentrations of boron and barium in western wheatgrass along the rim, but the contents are well below any toxic levels.

In summary, the elevated areas along the Roan Cliffs appear to be best suited for reclamation with regards to natural soil and plant characteristics. Under altered conditions, it is not known if the area will remain the best choice. Kilkelly and Lindsay (1979) reported an increase of boron and molybdenum in plants grown at the Anvil Points experimental revegetation plot (1737 $m$ elevation) relative to plants grown at a "high elevation" $(2225 \mathrm{~m})$ experimental revegetation plot located in the central part of the basin. Stollenwerk (1980) concluded that the most suitable locations for disposal of oil-shale wastes are in small gulches at low elevation because greater amounts of precipitation at higher elevations could result in production of significant quantities of leachate and deterioration of water quality downstream from disposal sites. In view of our results, these low-elevation disposal sites should not be located in high-trace-element areas south of the Roan Cliffs. Acceptable quality in all media (soils, plants, and waters) may be possible at lower elevation reclamation sites located in the northern part of the basin; however, molybdenum is generally enriched in these northern basin soils, and if an increase in $\mathrm{pH}$ due to oil shale waste were to occur, molybdenum may be further mobilized making it available to plants.

\section{REVEGETATION PLOT STUDY}

The results of geochemical and biogeochemical analyses for the revegetation plot study are summarized in table 8 . As with the basin study data, a $\log _{10}$-transformation was used except for $\mathrm{pH}$ measurements.

The estimated variance components associated with topsoil treatments, adjacent lysimeters, and repeated analyses are given in table 9. Analytical error for 17 properties was greater than 50 percent (table 9); therefore, these properties were excluded from further interpretation. Mean values for 20 soil properties as a function of topsoil depth are illustrated in figure 7 . Mean values for 7 properties in western wheatgrass are shown in figure 8. Soils in lysimeters with topsoil over spent shale and control lysimeters are fairly uniform in composition; whereas, soils in lysimeters which contained only spent shale have either significantly higher or lower concentrations of geochemical properties as compared to topsoil-containing and control lysimeters.
This suggests that a little topsoil makes a large difference in soil composition but that adding to a thicker layer of topsoil does not result in a significant change in soil composition.

The histograms of figure 8 for western wheatgrass suggests that varying amounts of topsoil show three patterns of elemental uptake. The first pattern is a decrease in molybdenum with increasing topsoil depth; 40 $\mathrm{cm}$ of topsoil over spent shale significantly decreases accumulation. The second pattern is an increase in concentrations of barium, calcium, manganese, and zinc with increasing topsoil depth. The third pattern is the low concentration of strontium in western wheatgrass grown on spent shale and an increase in the concentration of strontium when grown on topsoil regardless of depth.

The decrease in molybdenum accumulation and the independence of fluorine in western wheatgrass as a result of increasing topsoil depth is consistent with results reported by Kilkelly and Lindsay (1979). The independence of boron, copper, fluorine, iron, manganese, sodium, nickel, phosphorus, and zinc in western wheatgrass with respect to increasing topsoil depth is consistent with results reported by Schwab, Lindsay, and Marx (1980). Kilkelly and Lindsay conducted their study at a revegetation plot at Anvil Points using lysimeters containing U.S. Bureau of Mines and $\mathrm{TOSCO}^{3}$ processed spent shale overlain by varying depths of topsoil. Schwab, Lindsay, and Marx sampled lysimeters containing Paraho ${ }^{3}$ processed spent shale overlain by varying depths of topsoil. These lysimeters are located at Colorado State University's Intensive Revegetation site in Piceance basin.

Table 10 compares the results of analyses of the revegetation plot samples and the baselines from table 3 for those properties that did not show regional variation. The expected 95-percent (baseline) for Supertownship 12 (see supertownship index map in the Appendix) was used for those properties that do show regional variation because the revegetation plot is located in Supertownship 12, and the topsoil used in the lysimeters was collected within the supertownship.

A major concern in revegetation is element toxicity in plants and subsequent toxicity in animals. The results from this study show that elemental concentrations in western wheatgrass grown on the revegetation plots are not significantly greater than baseline values

(Text continues on p. E39.)

${ }^{3}$ The TOSCO process retorts oil shale at $482^{\circ} \mathrm{C}$ in an atmosphere of pyrolysis gases. The Paraho process retorts oil shale at $600^{\circ} \mathrm{C}$ in an atmosphere of air and combustion-derived carbon dioxide. 
TABLE 8.-Summary statistics for geochemical properties of 17 soil samples and biogeochemical properties of 17 western wheatgrass samples collected from Anvil Points experimental revegetation plot

(Plant variables are reported on a dry weight basis. $n$, number of samples which contained concentrations above the lower limit of determination of the analytical method; pet, percent; ppm, parts per million; pk ht, peak height; expected 95-percent range, the range within which 95 percent of the population would be expected to occur]

\begin{tabular}{|c|c|c|c|c|c|}
\hline Property & $n$ & $\begin{array}{l}\text { Geometric } \\
\text { mean }\end{array}$ & $\begin{array}{l}\text { Geometric } \\
\text { deviation }\end{array}$ & $\begin{array}{l}\text { Observed } \\
\text { range }\end{array}$ & $\begin{array}{l}\text { Expected 95- } \\
\text { percent range }\end{array}$ \\
\hline \multicolumn{6}{|c|}{ Element concentrations in and } \\
\hline Al (pct) - & 17 & 4.5 & 1.05 & $4.2-4.9$ & $4.2-5.1$ \\
\hline B (ppm) - & 17 & 33 & 1.28 & $19-44$ & $20-54$ \\
\hline $\mathrm{Ba}(\mathrm{ppm})---$ & 17 & 540 & 1.26 & $390-900$ & $340-850$ \\
\hline $\mathrm{Be}(\mathrm{ppm})-\cdots$ & 16 & 1.3 & 1.24 & $<1.0-1.9$ & $.85-20$ \\
\hline $\mathrm{Ca}(\mathrm{pct})-----$ & 17 & 6.9 & 1.24 & $5.4-12$ & $4 \cdot 5-11$ \\
\hline $\mathrm{Ce}(\mathrm{ppm})-\cdots$ & 17 & 76 & 1.28 & $56-130$ & $47-120$ \\
\hline Co $(p p m)-\cdots-\infty$ & 17 & 7.5 & 1.19 & $6.7-10$ & $5.3-11$ \\
\hline $\operatorname{Cr}(\mathrm{ppm})-\cdots$ & 17 & 30 & 1.16 & $24-39$ & $22-40$ \\
\hline $\mathrm{Cu}(\mathrm{ppm})-$ & 17 & 29 & $1 \cdot 38$ & $16-62$ & $15-55$ \\
\hline$F(p c t)-\cdots$ & 17 & .08 & 1.38 & $.05-0.16$ & $.04-0.15$ \\
\hline Fe $(p c t)-\ldots$ & 17 & 2.0 & 1.06 & $1.8-2.1$ & $1.8-2.2$ \\
\hline $\mathrm{Ga}(\mathrm{ppm})-\cdots$ & 17 & 9.7 & 1.21 & $6.8-12$ & $6.7-14$ \\
\hline$K(p c t)$ & 17 & 1.8 & 1.05 & $1.6-2.0$ & $1.6-2.0$ \\
\hline La (ppm)- - & 17 & 35 & 1.22 & $27-52$ & $24-52$ \\
\hline Li (ppm)-- & 17 & 13 & 1.45 & $10-30$ & $6.3-27$ \\
\hline $\mathrm{Mg}(\mathrm{pct})-\ldots$ & 17 & 1.7 & $1 \cdot 36$ & $1.2-3.5$ & $.93-3.1$ \\
\hline Mn $(p p m)-\cdots$ & 17 & 350 & 1.17 & $270-460$ & $260-480$ \\
\hline Mo $(\mathrm{ppm})-$ & 17 & 3.9 & 1.53 & $2.6-11$ & $1.7-9.1$ \\
\hline $\mathrm{Na}(\mathrm{pct})-$ & 17 & .81 & 1.38 & $.63-1.9$ & $.43-1.5$ \\
\hline $\mathrm{Nb}(\mathrm{ppm})-\cdots$ & 17 & 14 & 1.22 & $10-19$ & $9.5-21$ \\
\hline Ni (ppm) - & 17 & 20 & 1.17 & $15-26$ & $15-27$ \\
\hline$P(p c t) \cdots$ & 17 & .11 & 1.45 & $.09-0.22$ & $.05-0.22$ \\
\hline $\mathrm{Pb}(\mathrm{ppm})-$ & 17 & 13 & 1.34 & $9.4-29$ & $7 \cdot 3-23$ \\
\hline Sc (ppm)-- & 17 & 7.6 & 1.23 & $5.9-11$ & $5.1-11$ \\
\hline Si (pct) & 17 & 26 & 1.18 & $17-30$ & $19-36$ \\
\hline $\mathrm{Sr}(\mathrm{ppm}) \cdots$ & 17 & 310 & 1.35 & $220-620$ & $170-560$ \\
\hline Ti $(p p m)--n$ & 17 & .17 & 1.29 & $.10-0.27$ & $.10-0.28$ \\
\hline$V(p p m) \cdots$ & 17 & 74 & 1.14 & $58-100$ & $57-96$ \\
\hline$Y(p p m)-\cdots$ & 17 & 26 & 1.25 & $18-42$ & $17-40$ \\
\hline $\mathrm{Yb}(\mathrm{ppm})-\cdots$ & 17 & 1.4 & $1 \cdot 34$ & $.74-2.1$ & $.79-2.5$ \\
\hline $\mathrm{Zn}(\mathrm{ppm})-\cdots$ & 17 & 120 & 1.79 & $71-950$ & $36-370$ \\
\hline $\mathrm{Zr}(\mathrm{ppm})-$ & 17 & 230 & 1.78 & $63-760$ & $74-710$ \\
\hline Carbonate C (pct) & 17 & 1.6 & 1.47 & $.89-3.8$ & $.74-3.3$ \\
\hline Organic C (pct)-- & 17 & 1.9 & 1.41 & $1.2-3.8$ & $.94-3.7$ \\
\hline Total C (pct)--- & 17 & 3.5 & 1.36 & $2.6-7.5$ & $1.9-6.4$ \\
\hline $\mathrm{pH}^{1}-\cdots$ & 17 & $8 \cdot 0$ & .34 & $7.6-8.7$ & $7.3-8.7$ \\
\hline Calcite (pk ht) -- & 17 & 15 & 1.27 & $9-22$ & $9-24$ \\
\hline Clay (pk ht)---- & 17 & 2 & 1.42 & $1-3$ & $1-4$ \\
\hline Dolomite (pk ht)- & 17 & 5 & $1 \cdot 52$ & $4-16$ & $3-14$ \\
\hline \multicolumn{6}{|c|}{ Potassium feldspar } \\
\hline (pk ht) - - & 17 & 4 & 1.72 & $2-19$ & $1-12$ \\
\hline Quartz (pk ht)--- & 17 & 67 & $1 \cdot 55$ & $20-96$ & $28-161$ \\
\hline $\begin{array}{l}\text { Sodium feldspar } \\
\text { (pk ht) }\end{array}$ & 17 & 6 & 1.63 & $3-18$ & $2-16$ \\
\hline
\end{tabular}


TABLE 8.-Summary statistics for geochemical properties of 17 soil samples and biogeochemical properties of 17 western wheatgrass samples collected from Anvil Points experimental revegetation plot-Continued

\begin{tabular}{|c|c|c|c|c|c|}
\hline Property & $n$ & $\begin{array}{c}\text { Geometric } \\
\text { mean }\end{array}$ & $\begin{array}{l}\text { Geometric } \\
\text { deviation }\end{array}$ & $\begin{array}{l}\text { Observed } \\
\text { range }\end{array}$ & $\begin{array}{l}\text { Expected } 95- \\
\text { percent range }\end{array}$ \\
\hline \multicolumn{6}{|c|}{ Element concentrations in DTPA extract of soil ${ }^{2}$} \\
\hline $\begin{array}{l}\mathrm{B} \quad(\mathrm{ppm}) \\
\mathrm{Ca}(\mathrm{ppm}) \\
\mathrm{Cd} \quad(\mathrm{ppm}) \\
\mathrm{Cu} \quad(\mathrm{ppm}) \\
\mathrm{Fe} \quad(\mathrm{ppm})\end{array}$ & $\begin{array}{l}13 \\
13 \\
12 \\
13 \\
13\end{array}$ & $\begin{array}{l}0.57 \\
270 \\
.06 \\
2.6 \\
21\end{array}$ & $\begin{array}{l}1.47 \\
1.45 \\
1.85 \\
1.66 \\
2.79\end{array}$ & $\begin{aligned} 0.36 & -1.50 \\
90 & =360 \\
<0.02 & =0.16 \\
1.6 & =8.6 \\
5.2 & =200\end{aligned}$ & $\begin{array}{l}0.26-1.23 \\
130-560 \\
.02-0.20 \\
.94-7.1 \\
2.8-160\end{array}$ \\
\hline $\begin{array}{l}\mathrm{K}(\mathrm{ppm}) \\
\mathrm{Mg}(\mathrm{ppm}) \\
\mathrm{Mn}(\mathrm{ppm}) \\
\mathrm{Ni}(\mathrm{ppm}) \\
\mathrm{P} \quad(\mathrm{ppm})\end{array}$ & $\begin{array}{l}13 \\
13 \\
13 \\
13 \\
13\end{array}$ & $\begin{array}{l}220 \\
300 \\
7.8 \\
24 \\
.45\end{array}$ & $\begin{array}{l}1.34 \\
1.44 \\
1.37 \\
1.43 \\
2.18\end{array}$ & $\begin{array}{l}110-310 \\
210-740 \\
4.4-12 \\
.21-0.83 \\
6.2-79\end{array}$ & $\begin{array}{l}120-390 \\
150-610 \\
4.2-14 \\
.22-0.91 \\
5.2-110\end{array}$ \\
\hline $\begin{array}{l}\mathrm{Pb} \quad(\mathrm{ppm}) \\
\mathrm{Sr}(\mathrm{ppm}) \\
\mathrm{V}(\mathrm{ppm}) \\
\mathrm{Y} \quad(\mathrm{ppm}) \\
\mathrm{Zn} \quad(\mathrm{ppm})\end{array}$ & $\begin{array}{l}13 \\
13 \\
13 \\
13 \\
13\end{array}$ & $\begin{array}{c}1.9 \\
2.2 \\
.58 \\
16^{.21}\end{array}$ & $\begin{array}{l}1.35 \\
1.27 \\
1.44 \\
1.36 \\
3.74\end{array}$ & $\begin{array}{l}1.3-4.0 \\
1.2-2.8 \\
.43-1.5 \\
.13-0.33 \\
2.9-560\end{array}$ & $\begin{array}{l}1.1-3.4 \\
1.4-3.5 \\
.28-1.2 \\
.11-0.38 \\
1.1-220\end{array}$ \\
\hline \multicolumn{6}{|c|}{ Element concentrations in western wheatgrass } \\
\hline $\begin{array}{l}\mathrm{A} 1 \quad(\mathrm{ppm}) \\
\mathrm{B}(\mathrm{ppm}) \\
\mathrm{Ba}(\mathrm{ppm}) \\
\mathrm{Ca}(\mathrm{pct}) \\
\mathrm{Cu} \quad(\mathrm{ppm})\end{array}$ & $\begin{array}{l}16 \\
17 \\
17 \\
17 \\
17\end{array}$ & $\begin{array}{l}43 \\
8.2 \\
16 \\
.18 \\
2.8\end{array}$ & $\begin{array}{l}1.38 \\
1.34 \\
1.34 \\
1.31 \\
1.24\end{array}$ & $\begin{array}{l}<30-77 \\
5.8-17 \\
7.8-22 \\
.09-0.25 \\
1.7-3.6\end{array}$ & $\begin{array}{l}23-81 \\
4.6-15 \\
9.0-28 \\
.11-0.31 \\
1.8-4.3\end{array}$ \\
\hline $\begin{array}{l}\text { F (ppm) } \\
\text { Fe (ppm) } \\
\text { Mg (pct) } \\
\text { Mn (ppm) } \\
\text { Mo (ppm) }\end{array}$ & $\begin{array}{l}17 \\
17 \\
17 \\
17 \\
17\end{array}$ & $\begin{array}{l}5.5 \\
22^{26} \\
1.8\end{array}$ & $\begin{array}{l}1.36 \\
1.23 \\
1.26 \\
1.98 \\
1.67\end{array}$ & $\begin{array}{l}3.0-9.0 \\
28-62 \\
.09-0.19 \\
4.2-42 \\
.90-5.7\end{array}$ & $\begin{array}{l}3.0-10 \\
28-63 \\
.08-0.20 \\
6.8-99 \\
.70-4.9\end{array}$ \\
\hline $\begin{array}{l}\mathrm{Na}(\mathrm{ppm}) \\
\mathrm{P}(\mathrm{pct}) \\
\mathrm{Sr}(\mathrm{ppm}) \\
\mathrm{Zn}(\mathrm{ppm}) \\
\text { Ash (pct) }\end{array}$ & $\begin{array}{l}17 \\
17 \\
17 \\
17 \\
17\end{array}$ & $\begin{array}{l}150 \\
25^{\circ} \\
14 \\
7.2\end{array}$ & $\begin{array}{l}1.37 \\
1.29 \\
1.37 \\
1.17 \\
1.17\end{array}$ & $\begin{array}{l}81-250 \\
.10-0.24 \\
10-33 \\
11-19 \\
5.2-9.6\end{array}$ & $\begin{array}{l}110-210 \\
.10-0.26 \\
13-46 \\
10-19 \\
5.3-9.8\end{array}$ \\
\hline
\end{tabular}

${ }_{2}^{1}$ Arithmetic mean and deviation.

2 Because of insufficient sample quantity, these statistics are based on 13 samples instead of 17 . 
TABLE 9.-Total logarithmic variance and variance components, as percentage of the total logarithmic variance, for geochemical properties of 17 soil samples and biogeochemical properties of 17 western wheatgrass samples from Anvil Points experimental revegetation plot

\begin{tabular}{|c|c|c|c|c|}
\hline \multirow[b]{2}{*}{ Property } & \multirow[b]{2}{*}{$\begin{array}{c}\text { Total } \\
\text { logarithmic } \\
\text { variance }\end{array}$} & \multicolumn{3}{|c|}{ Variance components as percentage of total variance } \\
\hline & & $\begin{array}{c}\text { Among } \\
\text { topsoil } \\
\text { treatments }\end{array}$ & $\begin{array}{l}\text { Among } \\
\text { ad jacent } \\
\text { lysimeters }\end{array}$ & $\begin{array}{l}\text { Among } \\
\text { a nalyses }\end{array}$ \\
\hline \multicolumn{5}{|c|}{ Elements in and mineralogy of soil } \\
\hline $\mathrm{A} 1-\cdots-\cdots-\cdots$ & 0.0004 & 36 & ${ }^{1} 62$ & 2 \\
\hline B-C-n- & .0116 & 0 & 1 & 99 \\
\hline $\mathrm{Ba}-\cdots+\cdots$ & .0187 & 26 & 0 & 74 \\
\hline Be--n-- - - - & .0163 & 36 & 0 & 64 \\
\hline $\mathrm{Ca}-\cdots+\cdots$ & .0096 & ${ }^{1} 88$ & ${ }^{1} 12$ & 0 \\
\hline $\mathrm{Ce}-\cdots+\cdots-\infty-\cdots$ & .0147 & 0 & 58 & 42 \\
\hline $\mathrm{Cr}-\cdots$ & .0043 & 33 & 28 & 39 \\
\hline $\mathrm{Co}---1+-$ & .0067 & $1_{50}$ & 0 & 50 \\
\hline $\mathrm{Cu}-\cdots$ & .0208 & 50 & 19 & 31 \\
\hline 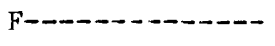 & .0215 & ${ }^{1} 77$ & ${ }^{1} 21$ & 2 \\
\hline $\mathrm{Fe}-\cdots$ & .0006 & 33 & $1_{62}$ & 0 \\
\hline $\mathrm{Ga}-\mathrm{C}$ & .0073 & 0 & 42 & 58 \\
\hline K-- & .0050 & 0 & $1_{96}$ & 4 \\
\hline La-C-C-n- & .0083 & 0 & 50 & 50 \\
\hline Li- & .0280 & ${ }^{1} 74$ & 17 & 9 \\
\hline $\mathrm{Mg}-\cdots$ & .0195 & $1_{86}$ & $1_{14}$ & 0 \\
\hline Mn & .0076 & 0 & 0 & 100 \\
\hline 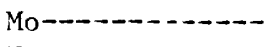 & .0375 & 57 & 140 & 3 \\
\hline $\mathrm{Na}-\mathrm{N}_{1}$ & .0222 & ${ }^{1} 95$ & $1_{4}$ & 1 \\
\hline $\mathrm{Nb}--\infty-\infty-\infty-\infty$ & .0078 & 29 & 15 & 56 \\
\hline Ni-C-N & .0058 & 25 & 0 & 75 \\
\hline P-1-n-n & .0290 & $1_{78}$ & $1_{19}$ & 3 \\
\hline $\mathrm{Pb}-\mathrm{H}_{1}$ & .0180 & 45 & 0 & 55 \\
\hline Sc- $-\infty-\infty-\infty+\infty$ & .0082 & 31 & 25 & 44 \\
\hline Si-n- & .0058 & ${ }^{1} 95$ & $1_{5}$ & 0 \\
\hline $\mathrm{Sr}-\cdots$ & .0199 & $1_{80}$ & 0 & 20 \\
\hline $\mathrm{Ti}$ & .0020 & $1_{80}$ & ${ }^{1} 18$ & 2 \\
\hline V-C-n- & .0038 & 0 & 51 & 49 \\
\hline Y-D-O- & .0099 & 49 & 19 & 32 \\
\hline $\mathrm{Yb}-\cdots+\cdots$ & .0226 & ${ }^{1} 65$ & 0 & 35 \\
\hline Zn- & .1106 & 0 & $1_{98}$ & 2 \\
\hline 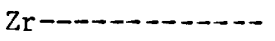 & .0669 & 40 & 36 & 24 \\
\hline Carbonate C---- & .0310 & ${ }^{1} 86$ & 2 & 12 \\
\hline Organic C----- & .0239 & 51 & 27 & 22 \\
\hline Total C- & .0199 & ${ }^{1} 89$ & 11 & 0 \\
\hline $\mathrm{pH}^{2}-\cdots$ & .1258 & 80 & 10 & 10 \\
\hline Calcite- & .0124 & 0 & 1 & 99 \\
\hline Clay-C-n-n & .0258 & $1_{77}$ & 3 & 20 \\
\hline Dolomite-- & .0360 & 58 & 21 & 21 \\
\hline \multicolumn{5}{|l|}{ Potassium } \\
\hline feldspar---- & .0729 & 0 & 12 & 88 \\
\hline Quartz-- & .0450 & $\mathrm{l}_{82}$ & 0 & 18 \\
\hline \multicolumn{5}{|l|}{ Sodiun } \\
\hline feldspar---- & .0465 & 11 & 43 & 46 \\
\hline
\end{tabular}


TABLE 9.-Total logarithmic variance and variance components, as percentage of the total logarithmic variance, for geochemical properties of 17 soil samples and biogeochemical properties of 17 western wheatgrass from Anvil Points experimental revegetation plot-Continued

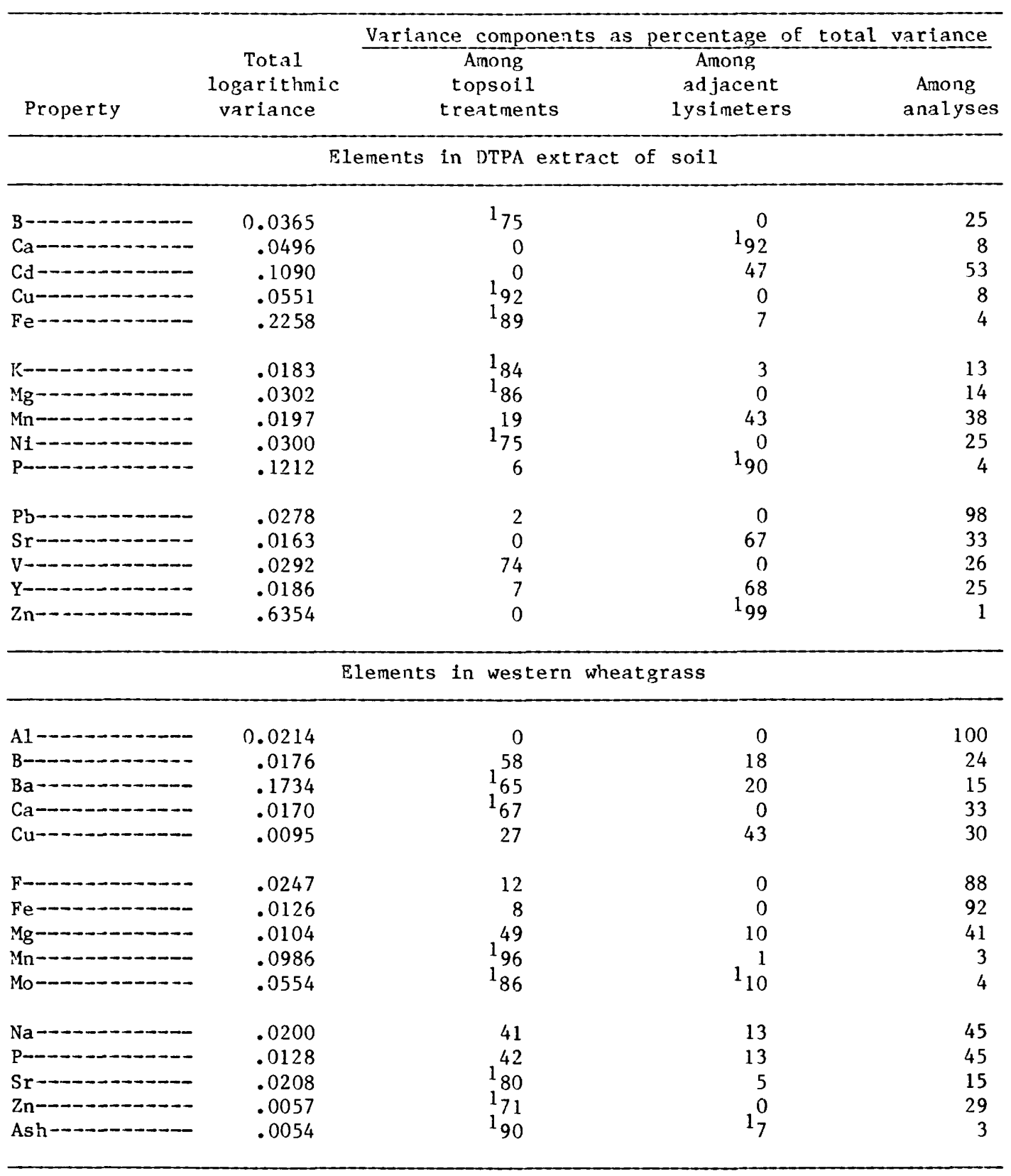

${ }^{1}$ Significantly different at 0.05 probability level.

2 Total arithmetic variance. 
E38
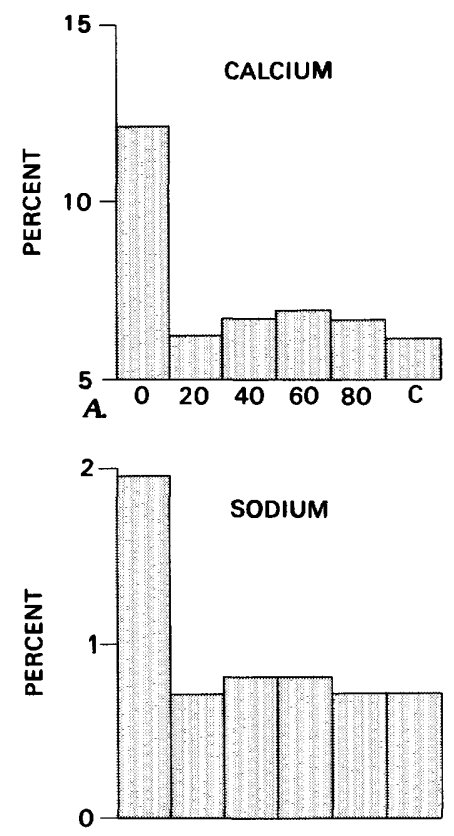

E.
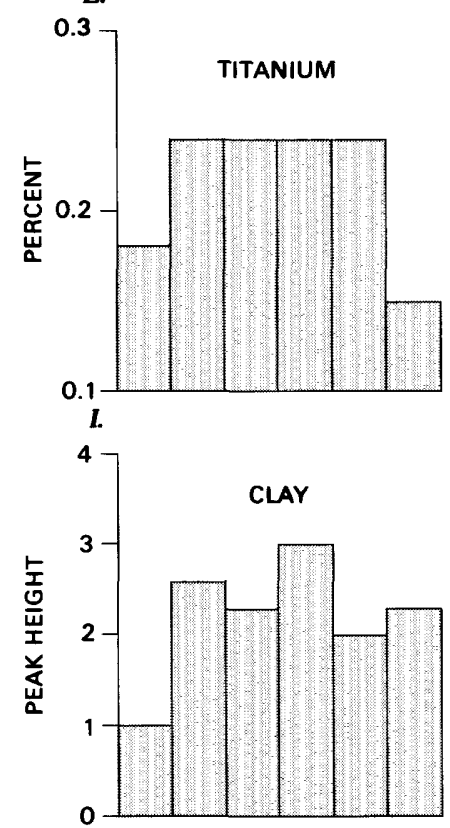

M.

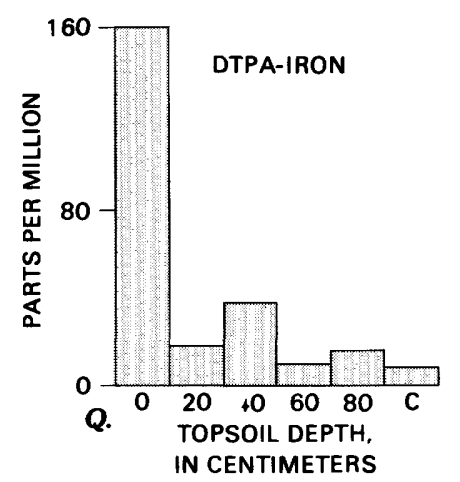

GEOCHEMICAL SURVEY OF THE WESTERN ENERGY REGION
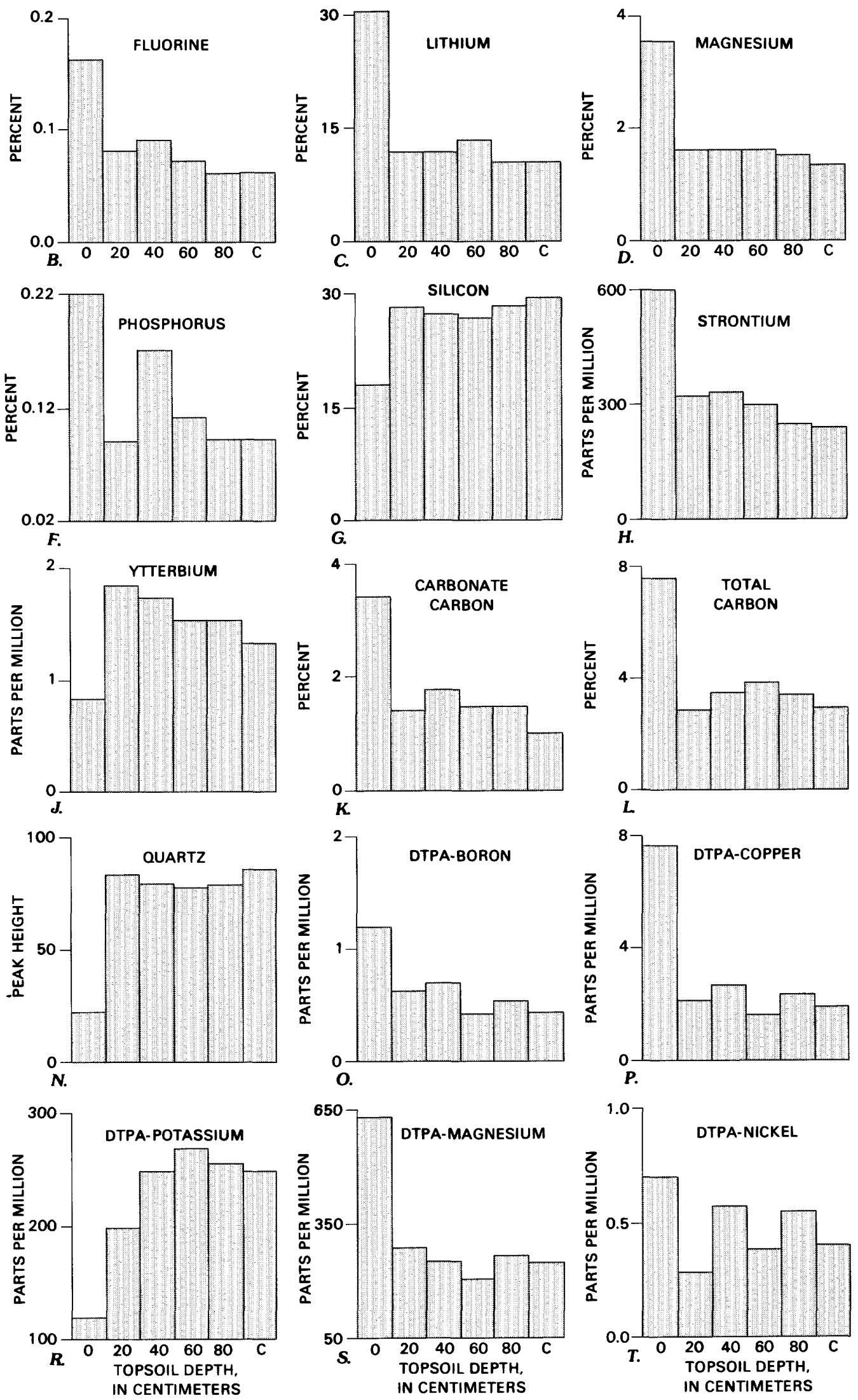

Figure 7.-HISTOGRAMS SHOWING RELATION BETWEEN GEOCHEMICAL PROPERTIES OF SOIL AND TOPSOIL DEPTH WITHIN THE LYSIMETER.

C, represents control lysimeter containing only topsoil. DTPA, extracted from soils with diethylenetriaminepentaacetic acid. 

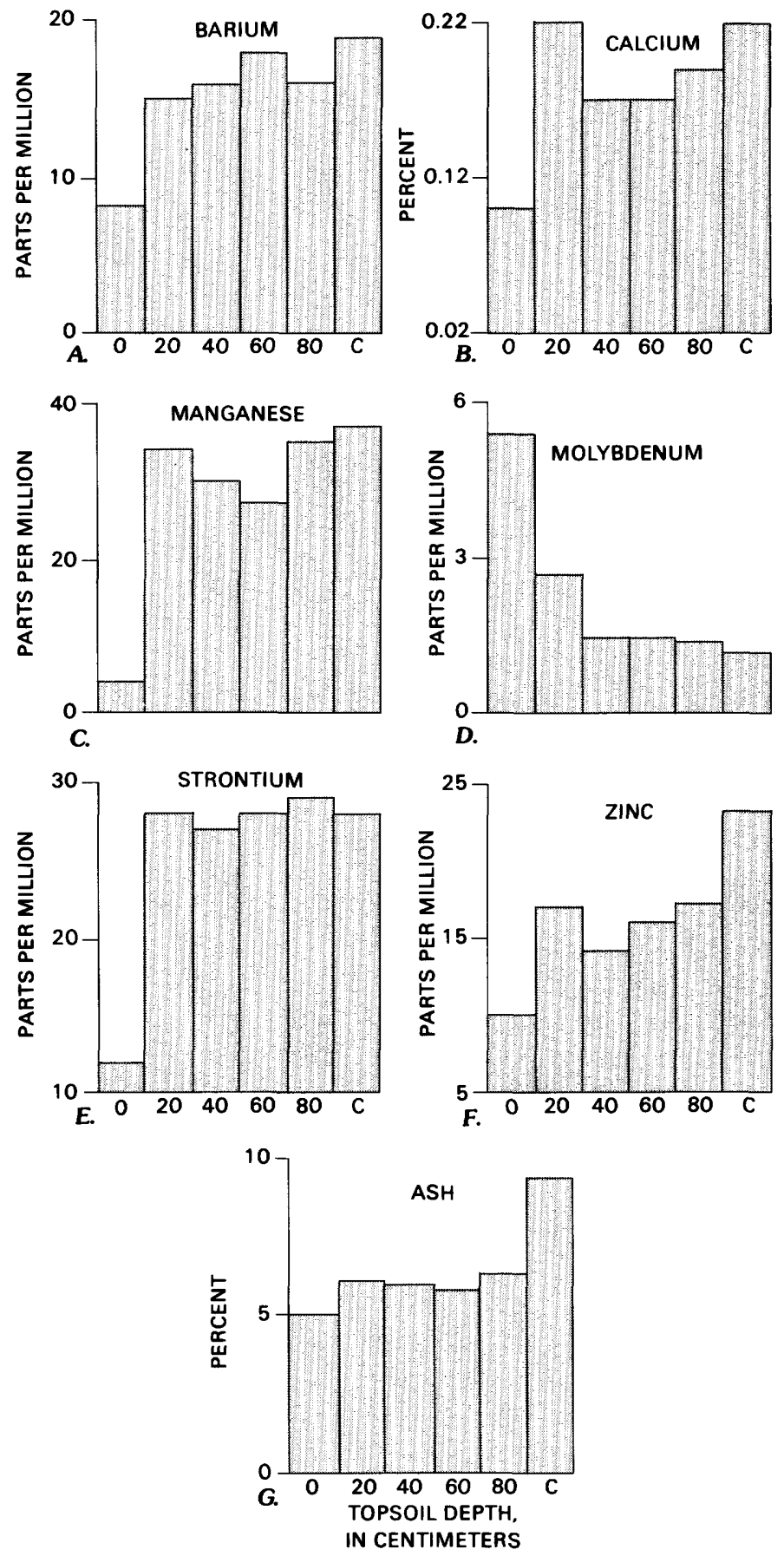

FIGURE 8.-HISTOGRAMS SHOWING RELATION BETWEEN GEOCHEMICAL PROPERTIES OF WESTERN WHEATGRASS AND TOPSOIL DEPTH WITHIN THE LYSIMETERS.

C, represents control lysimeter containing only topsoil. DTPA, extracted from soils with diethylenetriaminepentaacetic acid. for western wheatgrass growing in natural soils throughout the basin or in Supertownship 12. Some soil properties are significantly higher in revegetation plots than in natural soils due to fertilization and mulching of the revegetation plots. These differences, however, are not reflected in differences in western wheatgrass. Extrapolations of these results to other plant species or other areas of the basin are inappropriate because of variations in the chemical composition of different plant species and variations in the physiographic controls on elemental uptake by plants.

The increase in certain soil properties in the revegetation plot above baseline values is due to factors other than spent shale because concentrations of these properties also are elevated in control lysimeters. The increase in phosphorus is probably due to addition of nitrogen and phosphorous fertilizers. The increase in organic carbon, and consequently total carbon, are probably due to mulching. The increase in DTPA-extractable values is probably due to the increase of vegetative debris as illustrated by the $Q$-mode results in the basin study. The increase in zinc concentrations might be a result of contamination. One sample from one control lysimeter contained a 10-fold increase in zinc relative to samples from the adjacent control lysimeter.

The Anvil Points experimental revegetation plot is located in the area deemed least desirable by the Basin Study for revegetation activities. Toxic concentrations of elements in lysimeter plants were not observed, but these plants and associated soils are not in equilibrium with the surrounding lysimeter environment as is the natural soil-plant system. Given time, there is a possibility that toxic levels may develop.

\section{AVAILABILITY STUDY}

Equations showing relations between element concentrations in big sagebrush and western wheatgrass and various soil properties in the Piceance basin are given in table 11 . The independent soil variables used in the multiple regression procedure were total element concentration, organic and total carbon concentrations, $\mathrm{pH}$, relative mineral concentrations, and if applicable, DTPA-extractable element concentrations. Influences from undetermined soil properties, plant physiological processes, and environmental conditions, all contribute to the large range in the amount of variation (6-69 percent) accounted for by the equations.

Total element content in the soil is significant in only 8 of the 42 equations. DTPA-extractable elements only appear in seven of the equations. The lack of strong relations and the inconsistencies between elements in plants and soils suggest that plant uptake and accumulation of elements can not be explained by considering 


\begin{tabular}{|c|c|c|}
\hline Material & $\begin{array}{c}\text { Revegetation plot } \\
\text { significantly lower } \\
\text { than baseline }\end{array}$ & $\begin{array}{c}\text { Revegetation plot } \\
\text { significantly higher } \\
\text { than baseline }\end{array}$ \\
\hline $\begin{array}{l}\text { Elements in and } \\
\text { nineralogy of soil }\end{array}$ & $\begin{array}{l}\text { Fe, Sc, Ti, V, Y, and } \\
\text { Clay }\end{array}$ & $\begin{array}{l}\mathrm{P}, \mathrm{Zn} \text {, Organic Carbon, } \\
\text { and Total Carbon }\end{array}$ \\
\hline DTPA extracts of soil & $\mathrm{Ca}$ and $\mathrm{K}$ & $\mathrm{Cd}, \mathrm{Fe}, \mathrm{Mn}, \mathrm{Ni}, \mathrm{P}$, and $\mathrm{Zn}$ \\
\hline Western wheatgrass & $\begin{array}{l}\mathrm{Al}, \mathrm{Ca}, \mathrm{Fe}, \mathrm{Yn}, \mathrm{Mo}, \\
\mathrm{Zn} \text {, and Ash }\end{array}$ & \\
\hline
\end{tabular}

total or DTPA-extractable concentrations of elements in soils alone. As mentioned, many other factors interact within the plant-soil system.

Most equations are dominated by soil mineralogy which reflects the major source of the element to the available phases of the soil. Potassium feldspar occurs in the equation for boron in western wheatgrass and big sagebrush. Boron is thought to reside in authigenic potassium feldspars in the Green River and Uinta Formations (Sheppard and Gude, 1973). The boron would be released and readily mobilized by the alkaline weathering conditions. The equation for fluorine in western wheatgrass within the basin contains the variable clay. Saether, Runnells, and Meglen (1980) suggested that the fluorine substitutes for the hydroxyl group in illite. Similarly, sodium feldspar appears in the equation for sodium in western wheatgrass. Calcite appears in the equations for calcium, strontium, and zinc in big sagebrush and for molybdenum and strontium in western wheatgrass. Clay appears in eight equations for elements in big sagebrush and in five equations for elements in western wheatgrass. However, all correlations between elements in big sagebrush and clay are negative, and all correlations between elements in western wheatgrass and clay are positive. These opposite responses to clay content in soils are difficult to explain but may be due to either differences in species uptake, or differences in clay type or content with depth, or both. Big sagebrush has a much deeper root system than western wheatgrass. The use of soil mineralogy as a measure of availability is at best a first approximation. Mineralogy alone can suggest residences of some available elements, but there are other factors, as shown by the equations in table 11, which are suspected of controlling the actual exchange of ele- ments from the minerals to the plants. Potential reclamation problems may be identified for some elements using mineralogical studies of reclamation topsoil, but mineralogy alone is not recommended as an adequate measure of availability.

Soil properties, such as organic and total carbon content and $\mathrm{pH}$, are of limited use for predicting element uptake. Magnesium, calcium, and strontium in western wheatgrass, and copper, strontium, and zinc in big sagebrush are inversely proportional to soil organic carbon, which suggests either that the organic carbon is simply rendering the elements unavailable or that the organic carbon reflects a more complex inverse relationship with other soil properties that control availability. The latter relationship is suspected because most of these elements listed are associated with carbonate or clay minerals. Magnesium and copper in big sagebrush and copper in western wheatgrass are positively correlated with total soil carbon. Magnesium uptake is probably being controlled by carbonate minerals; however, it is doubtful that carbonate minerals are controlling copper uptake in either plant species. Barium, boron, calcium, and nickel in big sagebrush and barium in western wheatgrass are negatively correlated with $\mathrm{pH}$. Except for boron, which, due to its anionic nature, usually exhibits increasing mobility with increasing $\mathrm{pH}$, these elements interact with $\mathrm{pH}$ as expected. Copper, molybdenum, and sodium in big sagebrush and fluorine in western wheatgrass are positively correlated with $\mathrm{pH}$. Molybdenum and fluorine are usually more mobile at high $\mathrm{pH}$ because of their anionic characteristics. Sodium mobility is usually independent of $\mathrm{pH}$, and copper is expected to be immobile at higher $\mathrm{pH}$. Therefore, $\mathrm{pH}$ is a useful measurement in approximating element uptake for most elements that 
TABLE 11.-Statistically significant relations between elemental content of plants and soil chemical and mineralogical properties; the percentage of variance explained by the equations $\left(r^{2} \times 100\right)$, and the relative importance of each variable in the equation as determined by the ratios of the standard partial correlation coefficients

[Equations are based on 80 western wheatgrass and 80 big sagebrush samples collected in the Piceance basin. OC, organic carbon; TC, total carbon; K-spar, potassium feldspar; Na-spar, sodium feldspar]

\begin{tabular}{|c|c|c|c|}
\hline $\begin{array}{l}\text { Dependent } \\
\text { plant } \\
\text { property }\end{array}$ & $\begin{array}{l}\text { Independent } \\
\text { soil properties }\end{array}$ & $r^{2} \times 100$ & $\begin{array}{l}\text { Relative } \\
\text { importance } \\
\text { of variables }\end{array}$ \\
\hline \multicolumn{4}{|c|}{ Big sagebrush } \\
\hline $\log \mathrm{Al}=$ & $1.5-0.42 \log$ clay & 11 & \\
\hline $\log B=$ & $1.6+0.06 \log \mathrm{K}-\mathrm{spar}-0.4 \mathrm{pH}$ & 21 & $1 \cdot 3: 1 \cdot 0$ \\
\hline $\log \mathrm{Ba}=$ & $2.4-0.46 \log$ clay $-0.15 \mathrm{pH}$ & 24 & $1.0: 1.5$ \\
\hline $\log \mathrm{Ca}=$ & $\begin{array}{l}0.71-0.10 \log \mathrm{Na}-\mathrm{spar}+0.03 \text { log calcite } \\
-0.29 \log \mathrm{clay}-0.11 \mathrm{pH}\end{array}$ & 27 & $1.0: 1.4: 1 \cdot 5: 2 \cdot 4$ \\
\hline $\log \mathrm{Cu}=$ & $\begin{array}{l}0.43+0.40 \log \mathrm{DTPA}-\mathrm{Cu}+0.25 \log \mathrm{TC} \\
-0.39 \log \mathrm{OC}+0.07 \mathrm{pH}\end{array}$ & 50 & $1.4: 1.7: 3 \cdot 0: 1.0$ \\
\hline $\log \mathrm{Fe}=$ & $1.6-0.67 \log \mathrm{Fe}$ & 15 & \\
\hline $\log \mathrm{Mg}=$ & $\begin{array}{l}-9.4+0.10 \log \text { DTPA-Mg }+0.11 \log \mathrm{TC} \\
-0.36 \log \text { clay }\end{array}$ & 45 & $1 \cdot 0: 1 \cdot 3: 2 \cdot 3$ \\
\hline $\log \mathrm{Mn}=$ & $\begin{array}{l}0.41+0.26 \log M n+0.39 \log \text { quartz } \\
-0.62 \log \text { clay }\end{array}$ & 35 & $1 \cdot 0: 1 \cdot 5: 2 \cdot 3$ \\
\hline Log $M o=$ & $\begin{array}{l}-1.4-0.30 \log \mathrm{Na}-\mathrm{spar}+0.07 \log \text { dolomite } \\
+0.19 \mathrm{pH}\end{array}$ & 38 & $1 \cdot 6: 1 \cdot 0: 2 \cdot 3$ \\
\hline $\log \mathrm{Na}=$ & $-2.7-0.18 \log$ clay $+0.22 \mathrm{pH}$ & 41 & $1.8: 1.0$ \\
\hline $\log \mathrm{Ni}=$ & $1.2-0.18 \mathrm{pH}$ & 6 & \\
\hline $\log P=$ & $-0.65+0.15 \log P$ & 23 & \\
\hline $\log \mathrm{Sr}=$ & $\begin{array}{l}1.8+0.41 \log \text { DTPA-Sr }-0.15 \log \text { OC } \\
-0.13 \log \mathrm{Na-spar}+0.05 \log \text { calcite } \\
-0.62 \log \text { clay }\end{array}$ & 62 & $2 \cdot 0: 1 \cdot 3: 1 \cdot 0: 1 \cdot 7: 2 \cdot 4$ \\
\hline $\log \mathrm{Zn}=$ & $\begin{array}{l}0.48+0.59 \log \mathrm{Zn}+0.38 \log \text { DTPA-Zn } \\
-0.31 \log \text { OC }-0.19 \log \mathrm{K}-\mathrm{spar} \\
+0.04 \log \text { calcite }\end{array}$ & 51 & $1.2: 2.4: 1.8: 1 \cdot 0: 1.0$ \\
\hline
\end{tabular}

Western wheatgrass

\begin{tabular}{|c|c|c|c|c|}
\hline $\log$ & $\mathrm{Al}$ & $-2.1+0.52 \log$ clay & 11 & \\
\hline Log & B & $\begin{aligned}= & 0.60+0.21 \text { log K-spar }-0.07 \log \text { dolomite } \\
& +0.38 \log \text { clay }\end{aligned}$ & 22 & $1.1: 1 \cdot 0: 1 \cdot 0$ \\
\hline Log & $\mathrm{Ba}$ & $3.0-0.37 \log$ quartz $-0.13 \mathrm{pH}$ & 27 & $1.5: 1.0$ \\
\hline $\log$ & $\mathrm{Ca}$ & $\begin{array}{l}0.14 \log \text { oC }-0.26 \log \text { quartz } \\
-0.06 \text { log dolomite }+0.19 \log \text { clay }\end{array}$ & 42 & $1.6: 1.5: 1.6: 1.0$ \\
\hline Log & $\mathrm{Cu}$ & $-0.08+0.37 \log \mathrm{Cu}+0.23 \log \mathrm{TC}$ & 20 & $1.0: 1.5$ \\
\hline Log & F & $\begin{aligned}= & -0.02-0.06 \text { log dolomite }+0.36 \text { log clay } \\
& +0.07 \mathrm{pH}\end{aligned}$ & 29 & $1.0: 1 \cdot 2: 1 \cdot 0$ \\
\hline Log & $\mathrm{Fe}$ & $-2.3+0.60 \log \mathrm{Fe}$ & 11 & \\
\hline Log & $\mathrm{Mg}$ & $-1.4-0.18 \log$ OC $+0.23 \log$ DTPA-Mg & 34 & $1.1: 1.0$ \\
\hline $\log$ & Mn & $\begin{array}{l}0.69+0.40 \log M n-0.07 \log \text { dolomite } \\
-0.18 \log \text { DTPA-Mn }\end{array}$ & 31 & $1.2: 1.2: 1.0$ \\
\hline Log & : Yo & $\begin{array}{l}1.1+0.86 \text { log quartz }-0.39 \text { log Na-spar } \\
+0.08 \log \text { calcite }\end{array}$ & 29 & $1.2: 1.0: 1.0$ \\
\hline Log & $\mathrm{P}$ & $\begin{array}{l}-0.91-0.24 \text { log TC }-0.19 \text { log Na-spar } \\
+0.45 \text { DTPA-P }\end{array}$ & 37 & $1 \cdot 3: 1.0: 3 \cdot 0$ \\
\hline Log & $\mathrm{Sr}$ & $\begin{aligned}= & 2.0-0.41 \text { log OC }-0.27 \text { log quartz } \\
& +0.08 \text { log calcite }\end{aligned}$ & 61 & $3 \cdot 2: 1 \cdot 0: 2 \cdot 5$ \\
\hline$\sigma_{z}$ & $\mathrm{Zn}$ & $1.2-0.16 \log$ K-spar $+0.26 \log$ clay & 23 & $1.2: 1.0$ \\
\hline
\end{tabular}

$1_{\text {Only }}$ properties significant at 0.05 probability level were included in the equations. 
contain $\mathrm{pH}$ in their prediction equations. However, $\mathrm{pH}$ measurements alone do not provide an adequate assessment of element availability because they appear in only nine equations. Many different plant species are used in revegetation, and it would, therefore, be desirable if plant uptake could be predicted from only a few soil properties, rather than individual plant analyses. However, the equations in table 11 show that one or two soil properties will not adequately explain uptake in even two plant species grown under undisturbed conditions. Table 12 gives the prediction equations for elements in western wheatgrass grown on revegetation plots at Anvil Points. Uptake of fewer elements can be related to soil properties at this revegetation plot than in natural soils in the basin. The equations for the revegetation plots in table 12 explain a greater proportion of the total variation than the equations for the entire Piceance basin in table 11. This increase in the percent-variance explained is probably related to the homogeneous growing conditions (same soil, precipitation, elevation, and topographic aspect) encountered at the revegetation plot.

Total or extractable concentrations of elements are commonly determined in soil and rock materials to be used in reclamation to evaluate potential plant deficiency or toxicity conditions and to monitor changes over time. The usefulness of the soil tests included in this study for evaluating and monitoring deficiency or toxicity conditions in reclamation plant species is limited. Therefore, the development of reliable soil tests are needed because, once reclamation and revegetation of mined areas are completed, the amelioration of element deficiencies and toxicities is an added cost that might perhaps be avoided if adequate soil tests were available.

\section{CONCLUSIONS}

1. A variance analysis of soil geochemical and plant biogeochemical properties based on distance-related sampling intervals, resulted in maps showing regional variation for 29 soil properties, 9 big sagebrush properties, and 9 western wheatgrass properties. In addition, 24 properties in soil, 6 in big sagebrush, and 4 in western wheatgrass show no mappable regional variations; therefore, their variation was expressed as a baseline range. Boron and DTPA-extractable boron in soil; nickel, phosphorus, and vanadium in big sagebrush; and fluorine in western wheatgrass showed excessive analytical error and were not used further.

2. Soil geochemical maps reflect changes in lithology of soil parent material, elevation of sample sites, and (or) ground-water hydrology. Soils high in DTPA-extractable elements are found at high

TABLE 12.-Statistically significant relations between elemental content of western wheatgrass and soil chemical and mineralogical properties; the percentage of variance explained by the equations $\left(r^{2} \times 100\right)$, and the relative importance of each variable in the equation as determined by the ratios of the standard partial correlation coefficients

[Equations are based on 17 samples collected from Anvil Points revegetation plot. OC, organic carbon; TC, total carbon; K-spar, potassium feldspar; Na-spar, sodium feldspar]

\begin{tabular}{|c|c|c|c|}
\hline $\begin{array}{l}\text { Dependent } \\
\text { plant } \\
\text { property }\end{array}$ & $\begin{array}{l}\text { Independent } \\
\text { soil properties }\end{array}$ & $r^{2} \times 1 \cap 0$ & $\begin{array}{c}\text { Relative } \\
\text { importance } \\
\text { of variables }\end{array}$ \\
\hline $\log A 1=$ & $-2.2-0.40 \log$ clay & 32 & \\
\hline $\log \mathrm{Ba}=$ & $1.5-0.52 \log$ dolomite +0.25 log clay & 90 & $2 \cdot 5: 1.0$ \\
\hline $\log \mathrm{Ca}=$ & $0.08-0.68 \log \mathrm{TC}-0.38 \log$ calcite & 87 & $2.4: 1.0$ \\
\hline Log $\mathrm{Mg}=$ & $-0.29-0.31$ log quartz & 52 & \\
\hline $\log M n=$ & $\begin{array}{l}5.2+0.34 \text { log DTPA-Mn }-1.5 \text { log TC } \\
+0.21 \log \mathrm{Na}-\mathrm{spar}-0.42 \mathrm{pH}\end{array}$ & 99 & $1 \cdot 0: 4 \cdot 8: 1 \cdot 0: 3 \cdot 0$ \\
\hline Log Mo $=$ & $1.9-0.87 \log$ quartz & 59 & \\
\hline $\log \mathrm{Na}=$ & $-2.1+0.31 \log \mathrm{Na-spar}$ & 38 & \\
\hline $\log P=$ & $-0.41-0.47 \mathrm{log}$ dolomite & 57 & \\
\hline Log $\mathrm{Sr}=$ & $3.7-0.45 \log \mathrm{TC}-0.26 \mathrm{pH}$ & 92 & $1 \cdot 3: 1 \cdot 0$ \\
\hline $\log \mathrm{Zn}=$ & $1.4-0.33 \log$ dolomite & 80 & \\
\hline
\end{tabular}

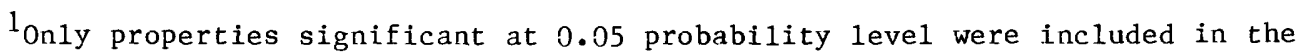
equations.
} 
elevation sites where the soil contains a high amount of vegetative debris. These sites are most common along the rim of the Roan Cliffs. Soils high in carbonate-related elements and minerals are found at sites along the northern part and the southwest corner of the basin where calcium-magnesium-bicarbonate enriched ground waters surface. Soils high in trace elements are found in the southeast corner of the basin. These trace elements are associated with high quartz, high clay, and high $\mathrm{pH}$ values in the soils. The high $\mathrm{pH}$ values result from low soil humus caused by increased aridity at the lower elevation sites.

3. On the basis of geochemical and biogeochemical data for natural soils, big sagebrush, and western wheatgrass, areas along the rim of the Roan Cliff may have the best potential for reclamation without developing toxic levels of trace elements in vegetation. Location of revegetation plots within this area and utilization of native topsoil might decrease the potential of toxicity in revegetation plants.

4. Concentrations of 20 soil properties and 7 western wheatgrass properties in samples collected from revegetation plots are related to topsoil depth over spent shale (figs. 7,8 ). The soil variation is attributed to differences in sampling material (spent shale and topsoil). Samples of spent shale from the lysimeters (represented by zero topsoil depth) have significantly higher or lower mean values of properties than samples from the lysimeters containing topsoil. Increasing topsoil depth $(20-80 \mathrm{~cm})$ has no effect on soil properties. Variations in chemical properties of plants (except sodium) are believed to be associated with varying amounts of topsoil. Sodium is low in samples grown on spent shale and uniformly higher in samples grown on topsoil regardless of depth of topsoil.

5. Comparisons of soil and plant properties in revegetation samples to baselines of these properties for the Piceance basin indicate that 15 properties of revegetation-plot soil had significantly lower than baseline values and that 10 revegetation-plot soil properties had significantly higher than baseline values. Element concentrations in wheatgrass grown in the revegetation-plot lysimeters are influenced by the underlying spent shale, but the concentrations are still within the limits of baseline concentrations.
6. Prediction equations for estimating element concentrations in plants from properties of native and altered sites explain from 6 to 99 percent of the total variance in element concentrations in plants. The equations were judged to have limited use because of the large number of variables required to adequately predict the expected concentrations, and also because many equations explain only a small proportion of the total variation.

\section{REFERENCES CITED}

Cochran, W. G., 1963, Sampling Techniques: New York, John Wiley and Sons, Inc., $413 \mathrm{p}$.

Coffin, D. L., Welder, F. A., and Glanzman, R. K., 1971, Geohydrology of the Piceance Creek Structural Basin between the White and Colorado Rivers, Northwestern Colorado: U.S. Geological Survey Hydrologic Investigations Atlas HA-370, Scale 1:125,000, 2 sheets.

Cohen, A. C., Jr., 1959, Simplified estimators for the normal distribution when samples are singly censored or truncated: Technometries, v. 1, no. 3, p. 217-237.

Dean, W. E., Ringrose, C. D., and Klusman, R. W., 1979, Geochemical variation in soils in the Piceance Creek basin: U.S. Geological Survey Bulletin 1479, $47 \mathrm{p}$.

DePuit, E. J., and Caldwell, M. M., 1973, Seasonal pattern of net photosynthesis of Artemisia tridentata: American Journal Botany, v. 60 , p. $426-435$.

Dorrzapf, A. F., Jr., 1973, Spectrochemical computer analysisargon-oxygen d-c arc method for silicate rocks: U.S. Geological Survey Journal of Research, v. 1, no. 5, p. 559-562.

Efroymson, M. A., 1960, Multiple regression analysis: Mathematical methods for digital computers: New York, John Wiley and Sons, Inc., v. 1, p. 191-203.

Harbert, H. P., and Berg, W. A., 1974, Vegetation stabilization of spent oil shales: Department of Agronomy, Colorado State University Environmental Resources Center Technical Report No. 4.

Harmes, T. F., 1976, Analyses of plants and plant ashes by methods other than emission spectroscopy, in A. T. Miesch, Geochemical Survey of Missouri-Methods of sampling laboratory analysis and statistical reduction of data: U.S. Geological Survey Professional Paper 954-A, p. A17.

Huffman, Claude Jr., and Dinnin, J. I., 1976, Analysis of rock and soils by atomic absorption spectrometry and other methods, in A. T. Miesch, Geochemical Survey of Missouri-Methods of sampling, laboratory analysis, and statistical reduction of data: U.S. Geological Survey Professsional Paper 954-A, p. A12-A14.

Jones, J. B., 1977, Elemental analysis of soil extracts and plant tissue ash by plasma emission spectroscopy: Communications in Soil Science and Plant Analysis, v. 8, no. 4, p. 349-365.

Kilkelly, M. K., and Lindsay, W. L., 1979, Trace elements in plants on processed oil shale, in Trace elements in oil shale progress report: U.S. Department of Energy Report C00-4017-3, p. 191253. 
Klovan, J. E., and Imbrie, John, 1971, An algorithm and FORTRANIV program for large-scale $Q$-mode factor analysis and calculation of factor scores: Journal of International Association of Mathematical Geology, v. 3, no. 1, p. 61-77.

Leone, F. C., Nelson, L. S., Johnson, N. L., and Eisenstat, Stanley, 1968, Sampling distributions of variance components II. Empirical studies of unbalanced nested designs: Technometrics, v. 10, no. 4, p. 719-737.

Lindsay, W. L., and Norvell, W. A., 1978, Development of a DTPA soil test for $\mathrm{Zn}, \mathrm{Fe}, \mathrm{Mn}$, and $\mathrm{Cu}$ : Soil Science Society of America Journal, v. 42, p. 421-428.

Miesch, A. T., 1967, Methods of computation for estimating geochemical abundance: U.S. Geological Survey Professional Paper 574 $\mathrm{B}, 15 \mathrm{p}$.

Murray, D. K., and Haun, J. D., 1974, Introduction to the geology of the Piceance Creek basin, in D. K. Murrray, ed., Rocky Mountain Association of Geologists guidebook to the energy resources of the Piceance Creek basin, Colorado: Denver, Rocky Mountain Association of Geologists, p. 29-39.

Nakagawa, H. M., Watterson, J. R., and Ward, F. N., 1975, Atomic absorption determination of molybdenum in plant ash, in New and refined methods of trace analysis useful in geochemical exploration: U.S. Geological Survey Bulletin 1408, p. 29-35.

National Research Council, U.S., and Department of Agriculture, Canada, 1971, Atlas of nutritional data on United States and Canadian feeds: National Academy of Sciences, Washington, D.C., U.S. Government Printing Office, 772 p.

Peech, Michael, 1965, Hydrogen-ion activity, in D. A. Black, ed., Methods of soil analysis; part 2, chemical and microbiological properties: Wisconsin, American Society of Agronomy (Agronomy, no. 9), p. 922-923.

Saether, O. M., Runnells, D. D., and Meglen, R. R., 1980, Trace elements in rich oil shales of the Mahogany Zone concentrated by differential density centrifugation, in Trace elements in oil shale progress report: U.S. Department of Energy Report C0010298-1, p. 237-255.

Schultz, L. G., 1964, Quantitative interpretation of mineralogical composition from X-ray and chemical data for the Pierre Shale: U.S. Geological Survey Professional Paper 391-C, 31 p.
Schwab, A. P., Lindsay, W. L., and Marx, G. P., 1980, Uptake of chemical elements by plants growing on spent shale, in Trace elements in oil shale progress report: U.S. Department of Energy Report C00-10298-1, p. 85-112.

Severson, R. C., Gough, L. P., and McNeal, J. M., 1977, Availability of elements in soils to native plants, Northern Great Plains: U.S. Geological Survey Open-file Report 77-847, 90 p.

Sheppard, R. A., and Gude, A. J., 3d, 1973, Boron-bearing potassium feldspar of authigenic origin in closed-basin deposits: U.S. Geological Survey Journal of Research, v. 1, no. 4, p. 377-382.

Soltanpour, P. N., and Schwab, A. P., 1977, A new test for simultaneous extraction of macro- and micro-nutrients in alkaline soils: Communications in Soil Science and Plant Analysis, v. 8, no. 3, p. 195-207.

Stollenwerk, K. G., 1980, Geochemistry of leachate from retorted and unretorted oil shale: Boulder, University of Colorado, Unpublished thesis, $182 \mathrm{p}$.

Taggart, J. E., Wahlberg, J. S., and Taylor, H. E., 1980, X-ray spectrometric major-element analyses of tephra samples from the May 18, 1980, eruption of Mt. St. Helens-samples collected from Washington, Idaho, and Montana: U.S. Geological Survey Open-file Report 80-1130, $13 \mathrm{p}$.

Tidball, R. R., and Ebens, R. J., 1976, Regional geochemical baselines in soils of the Powder River Basin, Montana-Wyoming, in R. B. Lauden, ed., Geology and energy resources of the Powder River Basin: Wyoming Geological Association Guidebook, 28th annual field conference, p. 299-310.

Tweto, Ogden, 1976, Preliminary geologic map of Colorado: U.S. Geological Survey Miscellaneous Field Studies Map MF-788, Scale 1:500,000, 2 sheets.

VanTrump, George, Jr., and Miesch, A. T., 1977, The U.S. Geological Survey RASS-STATPAC system for management and statistical reduction of geochemical data, in Computers and Geoscience, v. 3, p. 475-488.

Ward, F. N., Nakagawa, H. M., Harmes, T. F., and VanSickle, G. H., 1969, Atomic-absorption methods of analysis useful in geochemical exploration: U.S. Geological Survey Bulletin 1289, p. 25-33. 


\section{APPENDIX}




\section{APPENDIX}

This appendix is provided for those wishing to calculate supertownship baselines for geochemical properties showing statistically significant regional variation. The baselines for each supertownship are represented by the 95-percent expected range. This range represents the limits within which 95 percent of the supertownship population values would be expected to occur and is calculated from the following:

$$
\left(G M \div G D^{1.96}\right) \text { to }\left(G M \times G D^{1.96}\right)
$$

where $G M$ and $G D$ are the geometric mean and deviation respectively.

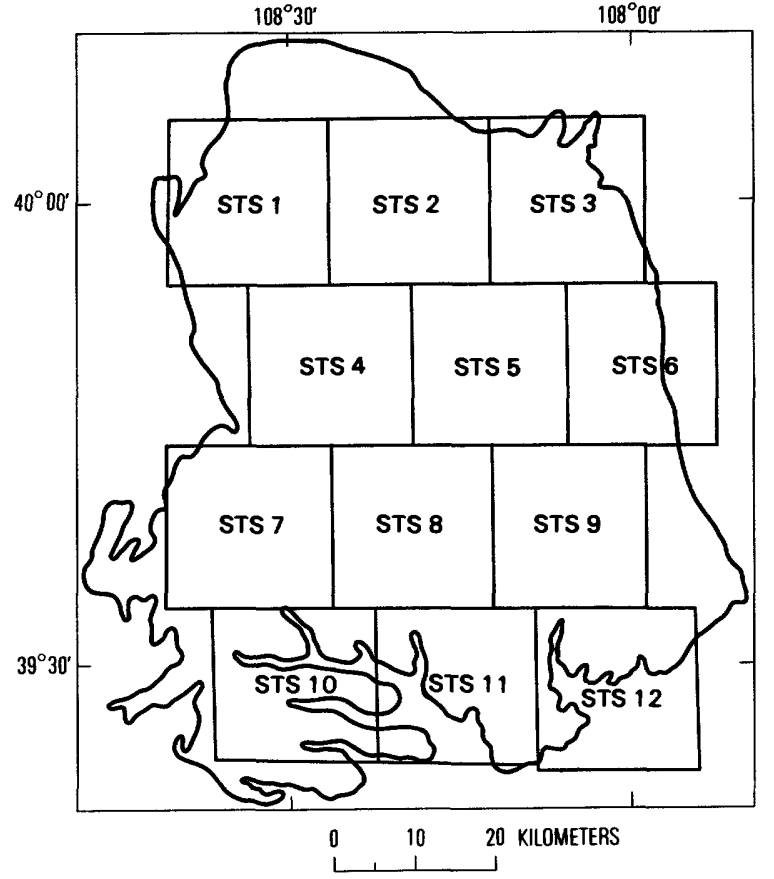

Supertownship Geometric means (geometric deviations)

\begin{tabular}{|c|c|c|c|c|c|c|c|c|c|c|c|c|c|c|c|c|c|c|c|c|c|c|c|c|}
\hline \multirow[b]{2}{*}{ Property } & \multirow{2}{*}{\multicolumn{2}{|c|}{ STS1 }} & & \multicolumn{21}{|c|}{ Supertownship (STS) } \\
\hline & & & & srs2 & & sts3 & & \$T\$4 & & sTs5 & & STS6 & & STS7 & & sTs8 & & STS9 & & STSII & & STSIt & & sTsi2 \\
\hline & & & & \multicolumn{21}{|c|}{ Total elements in and mineralogy of soll } \\
\hline A1 $(p c t)-\ldots$ & 5.1 & $(1.34)$ & 5.3 & $(1.17)$ & 5.3 & $(1.22)$ & 6.5 & $(1.04)$ & 6.0 & $(1.13)$ & 6.2 & $(1.12)$ & 6.5 & $(1.06)$ & 6.9 & $(1.05)$ & 6.2 & $(1.11)$ & 5.7 & $(1.04)$ & 6.9 & $(1.12)$ & 6.6 & $(1.18)$ \\
\hline Co $(\mathrm{ppm}) \ldots$ & 6.6 & $(1.18)$ & 9.4 & $(1.29)$ & 8.7 & $(1.28)$ & 11 & $(1.23)$ & 8.4 & $(1.31)$ & 12 & $(1.22)$ & 11 & $(1.14)$ & 14 & $(1.10)$ & 13 & $(1.11)$ & 8.4 & (1.13) & 11 & $(1.23)$ & 9.3 & $(1.24)$ \\
\hline Cu $(\mathrm{ppm})-\ldots$ & 20 & $(1.31)$ & 27 & $(1,12)$ & 24 & $(1,36)$ & 28 & $(1.16)$ & 26 & $(1.09)$ & 32 & $(1.21)$ & 30 & $(1.15)$ & 30 & $(1.14)$ & 31 & $(1.25)$ & 32 & $(1.17)$ & 35 & $(1.23)$ & 33 & $(1.41)$ \\
\hline le $(p C f)-\ldots$ & 1.8 & $(1.23)$ & 2.1 & $(1.21)$ & 2.0 & $(1.17)$ & 2.5 & $(1.09)$ & 2.2 & $(1.07)$ & 2.5 & $(1.09)$ & 2.7 & $(1.07)$ & 2.8 & $(1.10)$ & 2.6 & $(1.08)$ & 2.5 & $(1.04)$ & 3.1 & $(1.17)$ & 2.6 & $(1.16)$ \\
\hline Mn $(p p i n)-\ldots . .$. & 480 & $(1.22)$ & 780 & $(1.32)$ & 440 & $(1.45)$ & 490 & $(1.26)$ & $4 \mathrm{nn}$ & $(1.20)$ & 550 & $(1.25)$ & $\sin$ & $(1.18)$ & 540 & $(1.12)$ & 510 & $(1.21)$ & 460 & $(1.12)$ & 490 & $(1.21)$ & 290 & $(1.62)$ \\
\hline Na $(p(p), \ldots .$. & 1.1 & $(1.38)$ & 1.0 & $(1.30)$ & .97 & $(2.15)$ & 1.7 & (1.11) & 1.7 & $(1.71)$ & 1.4 & $(1.45$ & 1.2 & $(1.28)$ & $1 . R$ & $(1.32)$ & 1.4 & $(1.16)$ & .83 & $(1.32)$ & .57 & $7(1.41)$ & .62 & $(1.40)$ \\
\hline 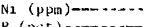 & 1) & $(1.26)$ & 23 & $(1.33)$ & 22 & $(1.27)$ & 27 & $(1.18)$ & 22 & $(1.21)$ & 31 & $(1.21)$ & 25 & $(1.10)$ & 31 & $(1.14)$ & 27 & $(1.19)$ & 21 & $(1.19)$ & 27 & $(1.20)$ & 28 & $(1.41)$ \\
\hline$p(p e t) \ldots$ & .05 & $(1.51)$ & .10 & $(1.30)$ & .06 & $(1.46)$ & .10 & $(1.56)$ & .09 & $(0.00)$ & .11 & $(1.24)$ & .10 & $(1.22)$ & .10 & $(1.22)$ & .10 & $(1.24)$ & .09 & $(1.24)$ & .06 & $h(1.45)$ & .05 & $(1.63)$ \\
\hline 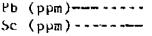 & ${ }^{11}$ & $\begin{array}{l}(1.72) \\
(\mathbf{p} .16)\end{array}$ & ${ }_{9.4}^{13}$ & $(1.33)$ & 13 & $(1.36)$ & 16 & $(1.28)$ & 13 & $(1.29)$ & 16 & $(1.25)$ & 15 & $(1.13)$ & 17 & $(1.23)$ & 17 & $(1.27)$ & ${ }_{9.9}^{11}$ & $(1.17) \cdot$ & $\begin{array}{l}21 \\
12\end{array}$ & $\begin{array}{l}(1.24) \\
(1.22)\end{array}$ & 18 & $\begin{array}{l}(1.46) \\
(1.30)\end{array}$ \\
\hline & & & & & & & & & & $(1.23)$ & & & & & & & & & & & & & & \\
\hline 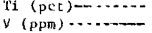 & $50^{.2 k}$ & $\begin{array}{l}(1.29) \\
(1.19)\end{array}$ & $68^{.29}$ & $\begin{array}{l}(1.19) \\
(1.21)\end{array}$ & $69^{-26}$ & $\begin{array}{l}(1.14) \\
(1,17)\end{array}$ & $77^{.30}$ & $\begin{array}{l}(1.08) \\
(1.19)\end{array}$ & $68^{.25}$ & $\begin{array}{l}(1.05) \\
(1.21)\end{array}$ & ${ }_{86}^{.30}$ & $\begin{array}{l}(1.10) \\
(1.10)\end{array}$ & $76^{.31}$ & $\begin{array}{l}1(1.05) \\
(1.10)\end{array}$ & $87^{-31}$ & $\begin{array}{l}(1.06) \\
(1.11)\end{array}$ & $80^{.30}$ & $\begin{array}{l}(1.15) \\
(1.16)\end{array}$ & $82^{.30}$ & $\begin{array}{l}(1.05) \\
(1.09)\end{array}$ & $96^{.34}$ & $\begin{array}{l}4(1.10) \\
(1.12)\end{array}$ & $100^{.33}$ & $\left(\begin{array}{l}(1.11) \\
(1.31)\end{array}\right.$ \\
\hline$Y(\mathrm{ppg})-\cdots$ & 25 & $(1.29)$ & 31 & $(1.15)$ & 25 & $(1.29)$ & 28 & (1.28) & 23 & $(1.21)$ & $\begin{array}{l}86 \\
27\end{array}$ & $(1.15)$ & 27 & $(1.16)$ & 26 & $(1.10)$ & 28 & $(1.12)$ & 33 & $(1.18)$ & 38 & $(1.27)$ & 39 & (1.31) \\
\hline $\mathrm{Zn}(\mathrm{ppm}) \cdots$ & 75 & $(1.46)$ & 76 & $(1.13)$ & 60 & $(1.20)$ & 72 & $(1.14)$ & 61 & $(1.16)$ & 75 & $(1.11)$ & 67 & $(1.1$ & & $(1.13)$ & 69 & $(1.25)$ & B2 & $(1.10)$ & 110 & $(1.18)$ & 92 & $(1.23)$ \\
\hline Orgatic $c(p c t)-$ & 2.3 & $(1.42)$ & 2.3 & $(1.52)$ & 2.0 & $(1.64)$ & 2.2 & $(1.78)$ & 3.5 & $(1.64)$ & 2.7 & $(1.52)$ & 3.7 & $(1.38)$ & 2.7 & $(1.50)$ & 3.8 & $(1.32)$ & 3.7 & $(1.31)$ & 1.2 & $(1.34)$ & .46 & $(1.68)$ \\
\hline lotal $Q$ (pct)- & 4.1 & $(1.67)$ & 3.3 & $(1.50)$ & 2.3 & $(1.81)$ & 2.4 & $(1.85)$ & 4.0 & $(1.65)$ & 2.9 & $(1.63)$ & 3.8 & $(1.41)$ & 2.8 & $(1.55)$ & 4.0 & $(1.39)$ & 5.1 & $(1.20)$ & & $(1.50)$ & .93 & $(1.97)$ \\
\hline $\mathrm{pH}^{-}-\mathrm{Cy}$ & 7.3 & $(1.10)$ & 7.7 & $(1.03)$ & 7.3 & $(1.05)$ & 7.2 & $(1,06)$ & 7.7 & $(1.03)$ & 7.4 & $(1.03)$ & 6.6 & $(1.1 n)$ & 7.0 & $(1.06)$ & 6.9 & $(1.13)$ & 7.5 & $(1.02)$ & 7.9 & $(1.01)$ & 8.0 & $(1.03)$ \\
\hline \multirow{4}{*}{$\begin{array}{l}\text { Lay }(p k h t) \\
\text { Jolomite (pk ht) } \\
\text { sodf um feldspar } \\
\text { (pk ht)- }\end{array}$} & 2 & $(1.28)$ & 2 & $(1.16)$ & 2 & $(1.18)$ & 2 & $(1.23)$ & 2 & $(1.38)$ & 2 & $(1.23)$ & 3 & $(0.0 n)$ & 3 & $(1.22)$ & & $(1.24)$ & 3 & $(1.25)$ & & & 4 & $(1.39)$ \\
\hline & & $(1.76)$ & 3 & $(1.40)$ & 2 & $(13.4)$ & 3 & $(1.53)$ & 8 & $(1.95)$ & 5 & $(1.64)$ & 2 & $(1.63)$ & 3 & $(1.42)$ & 3 & $(2.12)$ & 7 & $(1.43)$ & & & & \\
\hline & 6 & $(1.78)$ & 7 & $(1.32)$ & 8 & $(1.39)$ & 13 & $(1.15)$ & 9 & $(1,93)$ & 7 & $(1.69)$ & 10 & $(1.51)$ & 12 & $(1.65)$ & 11 & $(1.64)$ & 6 & $(1.54)$ & 5 & $(1.87)$ & 4 & $(1.95)$ \\
\hline & & & & \multicolumn{21}{|c|}{ DTPA extract of soil } \\
\hline $\mathrm{Ca}(\mathrm{ppn})-$ & 430 & $(1.20)$ & 460 & $(1.17)$ & 440 & $(1.11)$ & 440 & $(1.13)$ & 460 & $(1.12)$ & 440 & $(1.12)$ & 430 & $(1.11)$ & 430 & $(1.13)$ & 470 & $(1.08)$ & 430 & $(1.14)$ & 350 & $(1.11)$ & 340 & $(1.08)$ \\
\hline $\operatorname{cd}(p, \mu m)$ & .1 & $(1.99)$ & .0 & $(1.48)$ & .10 & $(2.54)$ & .09 & $(1.19)$ & .11 & $(3.53)$ & .15 & $(1.84)$ & .13 & $3(1.71)$ & .09 & $(1.76)$ & & $(1.34)$ & .16 & $(1.58)$ & .07 & & .02 & \\
\hline re (ppm) $)-\ldots . . .$. & 18 & $(1.47)$ & 16 & $(2.21)$ & 19 & $(1.38)$ & 23 & $(1.50)$ & 21 & $(1.56)$ & 23 & $(1.32)$ & so & $(1.53)$ & 37 & $(1.18)$ & 56 & $(1.36)$ & $3 n$ & $(1.77)$ & 8.6 & $(1.24)$ & 5.2 & (1.31) \\
\hline 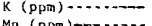 & 300 & $(1.32)$ & 240 & $(1.27)$ & 300 & $(1.46)$ & 350 & $(1.55)$ & 670 & $(2.20)$ & $46 n$ & $(1.76)$ & 430 & $(1.65)$ & 380 & $(1.42)$ & 530 & $(1.28)$ & 590 & $(1.48)$ & 340 & $(1.16)$ & 270 & $(1.20)$ \\
\hline Mn $(p \mathrm{pm})-\ldots$ & 10 & $(1.44)$ & 10 & $(1.70)$ & 9.8 & $(1.49)$ & 10 & $(1.12)$ & 16 & $(1.98)$ & 12 & $(1.49)$ & 17 & $(1.80)$ & 15 & $(1.51)$ & 21 & $(1.49)$ & 15 & $(1.48)$ & 7.7 & $(1.29)$ & 3.6 & $(i .26)$ \\
\hline Ni $(\mathrm{p} p \mathrm{~m}) \ldots$ & .36 & $(1.85)$ & .35 & $(2.04)$ & .33 & $(1.42)$ & .65 & $(1.45)$ & .36 & $(1.50)$ & .64 & $(1.77)$ & .97 & $(1.56)$ & .80 & $(1.23)$ & .77 & $(1.68)$ & .53 & $(1.38)$ & .31 & $1(1.78)$ & .13 & $(1.46)$ \\
\hline $\begin{array}{l}P(p p \ln )- \\
Y(p p m)\end{array}$ & 9.6 & $(1.49)$ & 7.9 & $(1.27)$ & 11 & $(1.68)$ & 13 & $(1.31)$ & 20 & (2.34) & 12 & $(1.50)$ & 18 & $(1.47)$ & 18 & $(1.21)$ & 20 & $(1.33)$ & 13, & & 5.3 & & 2.2 & \\
\hline \multirow{3}{*}{$\angle n(p p m) \ldots \ldots$} & & $(3.75)$ & .78 & $(2.52)$ & .99 & $(2.08)$ & 1.3 & $(1.81)$ & .92 & $(1.60)$ & 1.7 & $(1.53)$ & 2.7 & $(1.36)$ & 1.8 & $(1.51)$ & 2.1 & $(1.61)$ & 1.3 & & .44 & & .28 & \\
\hline & .92 & $(1.98)$ & .76 & $(1.45)$ & 1.5 & $(1.60)$ & 1.3 & $(1.55)$ & 2.1 & $(1.99)$ & 1.8 & $(1.91)$ & 2.8 & $(1.94)$ & 1.9 & $(1.23)$ & 3.7 & $(1.48)$ & 2.9 & $(1.57)$ & .78 & $8(1.29)$ & .36 & $(1.07)$ \\
\hline & & & & \multicolumn{21}{|c|}{ Big sagebrush } \\
\hline ва $(p p m)-\cdots$ & 20) & $(1.29)$ & 15 & $(1.19)$ & 13 & $(1.32)$ & 19 & $(1.07)$ & 8.9 & $(1.24)$ & 13 & $(1.90)$ & 14 & $(1.33)$ & & $(1.40)$ & 20 & $(1.57)$ & 6.5 & $(2.24)$ & 5.7 & $(1.7$ & 10 & $(1.23)$ \\
\hline$\cdots$ & & $(1.17)$ & & & .62 & & .59 & & .53 & & .58 & $(1.25)$ & .6 & & & & & & & & .47 & & & \\
\hline Cu $(p p m$ & & $(1.31)$ & $110^{\circ}$ & $(1.37)$ & 10 & $(1.17)$ & 13 & $(1.22)$ & 14 & $(1.38)$ & 9.0 & $(1.30)$ & 11 & $(1.14)$ & 9.1 & $(1.10)$ & 8.1 & 11.4 & 14 & $(1.22)$ & 16 & $(1.34)$ & 17 & $(1.24)$ \\
\hline Mg (pet) & .19 & $(1.17)$ & .16 & $(1.15)$ & .17 & $(1.12)$ & .17 & $(1.16)$ & .18 & $(1.17)$ & .18 & $(1.15)$ & .15 & $(1.13)$ & .13 & $(1.15)$ & .16 & $(1.17)$ & .17 & $(1.34)$ & .12 & & .11 & $(1.20)$ \\
\hline Ho $(\mathrm{ppOB})-\ldots$ & .80 & $(1.36)$ & .51 & $(1.34)$ & .93 & $(1.22)$ & .54 & $(1.82)$ & 1.0 & $(1.87)$ & .66 & $(1.52)$ & .33 & $(1.50)$ & .33 & $(1.61)$ & .31 & $(2.33)$ & 1.2 & $(1.40)$ & .69 & $9(1.32)$ & .86 & $(1.37)$ \\
\hline $\mathrm{Na}(p \mathrm{pm})-$ & 301. & $(1.43)$ & 490 & $(2.28)$ & 220 & $(2.02)$ & 340 & $(1.78)$ & 310 & $(2.03)$ & 160 & $(3.84)$ & 67 & $(1.69)$ & 61 & $(1.36)$ & 100 & $(2.26)$ & 91 & $(1.16)$ & 70 & $(1.42)$ & H5 & $(2.0 n)$ \\
\hline -.... & 54 & $(1.24)$ & 46 & & 37 & & 37 & $(1.1$ & 47 & & 35 & (1. & 21 & (1.) & 21 & & 27 & & 34 & & 25 & & 9 & (1.) \\
\hline \multirow{3}{*}{ Ash $(p c t) \ldots$} & 21 & $(1.31)$ & 23 & $(1.59)$ & 22 & $(1.17)$ & 28 & $(1.22)$ & 23 & $(1.5 n)$ & 22 & $(1.43)$ & 20 & $(1.17)$ & 20 & & 25 & (1.) & 37 & & 39 & & 36 & (1.) \\
\hline & 8.1 & $(1.09)$ & 7.4 & $(1.09)$ & 7.3 & $(1.15)$ & 7.5 & $(1.04)$ & 7.7 & $(1.11)$ & 7.1 & $(1.06)$ & 6.3 & $(1.04)$ & 6.1 & $(1.11)$ & h. 4 & $(1.10)$ & 7.5 & $(1.08)$ & 6.2 & $(1.05)$ & 6.0 & $(1.08)$ \\
\hline & & & & \multicolumn{21}{|c|}{ Western wheatgrass } \\
\hline$B(\mathrm{ppm})$ & 6.6 & $(1.18)$ & 5.2 & $(1.36)$ & 6.5 & $(1.29)$ & 6.4 & $(1.06)$ & 5.7 & $(1.4)$ & 7.3 & $(1.2$ & 8.7 & & 8.9 & & 7.6 & & h. 0 & & 14 & & 11 & \\
\hline $\mathrm{Ba}(\mathrm{ppm})-\cdots$ & 22 & $(1.25)$ & 18 & $(1.32)$ & 16 & $(1.41)$ & 26 & $(1.15)$ & 18 & (1.) & 19 & $(1.4$ & 22 & $(1.27)$ & 22 & $(1.59)$ & 31 & & 16 & & 13 & & & (1. \\
\hline Ca $(p \in t) \cdots$ & .35 & $(1.24)$ & .34 & $(1.26)$ & .31 & $(1.35)$ & .34 & $(1.21)$ & .28 & (1.) & .27 & $(1.1)$ & .33 & $(1.31)$ & .33 & $(1.23)$ & .33 & (1. & .24 & & .45 & & & $(1)$. \\
\hline Mg $(\mu c t)-$. & & $(1.22)$ & & $(1.19)$ & .09 & $(1.27)$ & .10 & $(1.26)$ & .10 & $(1.26)$ & .09 & $(1.28)$ & .10 & $(1.22)$ & .08 & $(1.21)$ & .10 & $(1.28)$ & .09 & & .14 & & .13 & \\
\hline Min (ppm)-- & 35 & $(1.20)$ & 40 & $(1.26)$ & 40 & $(1.46)$ & 34 & $(1.21)$ & 29 & $(1.24)$ & 32 & $(1.22)$ & 35 & $(1,36)$ & 25 & $(1.48)$ & 27 & $(1.30)$ & 41 & $(1.17)$ & 58 & $(1.23)$ & 43 & $(1.45)$ \\
\hline Mo (ppim) ......... & 1.1 & $(1.52$ & .71 & $(1.38)$ & 2.1 & $(1.28)$ & 1.3 & $(1.99)$ & 1.5 & $(1.69)$ & 1.4 & $(2.21)$ & .84 & $(1.93)$ & .72 & $(1.43)$ & 1.3 & $(1.67)$ & 3.2 & $(1.2)$ & 2.3 & $(1,77)$ & 3.4 & (1. \\
\hline & 27 & $(1.32)$ & 22 & & & $(1.79)$ & 19 & $(1.27)$ & 23 & $(1.21)$ & $15^{104}$ & $(1.46)$ & $14^{.04}$ & $(1.33)$ & $2 n^{016}$ & & $16^{103}$ & (1.2 & 16.2 & & $3 i$ & & 55 & (1.) \\
\hline $\ln _{n}\left(p p_{i n}\right) \ldots$ & 14 & $(1.18)$ & 12 & $(1.25)$ & 19 & $(1.26)$ & 20 & $(1.32)$ & 17 & (1.34) & 15 & $(1.26)$ & 16 & $(1.25)$ & 13 & $(1.32)$ & 17 & $(1.23)$ & 20 & $(1.16)$ & 22 & $(1.29)$ & 21 & $(1.39)$ \\
\hline Ash $(p c t)-\cdots$ & 8.3 & $(1.09)$ & 7.5 & $(1.09)$ & 8.4 & $(1.21)$ & 9.2 & (1.11) & 8.4 & $(1.07)$ & 8.4 & $(1.06)$ & 7.9 & $(1.09)$ & 7.3 & $(1,16)$ & 8.2 & $(1.19)$ & 9.6 & $(1.06)$ & 12 & $(1.17)$ & 13 & $(1,10)$ \\
\hline
\end{tabular}



